\title{
CURRENT TAXONOMY OF THE LICHEN FAMILY TELOSCHISTACEAE FROM INDIA WITH DESCRIPTIONS OF NEW SPECIES
}

\author{
G. K. Mishra ${ }^{1}$, D. K. Upreti' ${ }^{1}$, S. Nayaka ${ }^{1 *}$, A. Thell ${ }^{2}$, I. Kärnefelt ${ }^{2}$ \\ L. LőKös ${ }^{3}$, J.-S. Hur ${ }^{4}$, G. P. Sinha ${ }^{5}$ and S. Y. KondRATYUK ${ }^{6}$ \\ ${ }^{1}$ CSIR-National Botanical Research Institute, Rana Pratap Marg, Lucknow-226001 \\ Uttar Pradesh, India; E-mail: nayaka.sanjeeva@gmail.com \\ ${ }^{2}$ Lund University, Biological Museum, Botanical Collections, Box 117, SE-221 00 Lund, Sweden \\ ${ }^{3}$ Department of Botany, Hungarian Natural History Museum, H-1431 Budapest, Pf. 137, Hungary \\ ${ }^{4}$ Korean Lichen Research Institute, Sunchon National University, Sunchon 540-742, South Korea \\ ${ }^{5}$ Botanical Survey of India, Central Regional Centre, Allahabad 211002, Uttar Pradesh, India \\ ${ }^{6}$ M. H. Kholodny Institute of Botany, Tereshchenkivska str. 2, 01004 Kiev, Ukraine
}

(Received: 13 February 2020; Accepted: 3 June 2020)

The present study recorded 36 genera and 115 species of the lichen family Teloschistaceae in India. Three species, i.e. Caloplaca rajasthanica S. Y. Kondr., Upreti et G. P. Sinha, Huriella upretiana S. Y. Kondr., G. K. Mishra, Nayaka et A. Thell, and Squamulea uttarkashiana S. Y. Kondr., Upreti, Nayaka et A. Thell, are described as new species. Seven new combinations, i.e. Fulgogasparrea awasthii (Y. Joshi et Upreti) S. Y. Kondr., Upreti et A. Thell, Neobrownliella cinnabarina (Ach.) S. Y. Kondr., Upreti et A. Thell, Neobrownliella holochracea (Nyl.) S. Y. Kondr., Upreti et A. Thell, Opeltia flavorubescens (Huds.) S. Y. Kondr. et J.-S. Hur, Oxneriopsis bassiae (Willd. ex Ach.) S. Y. Kondr., Upreti et J.-S. Hur, Upretia hueana (B. de Lesd.) S. Y. Kondr. et Upreti and Megaspora subpoliotera (Y. Joshi et Upreti) S. Y. Kondr., Upreti et A. Thell, are proposed based on nrITS phylogeny in the Teloschistaceae and Megasporaceae consequently. Validation of combination Olegblumia demissa is provided. Molecular data on Fulgogasparrea awasthii and Megaspora subpoliotera are recorded from India for the first time. Four new genera including one species each, i.e. Lazarenkoiopsis ussuriensis (Oxner, S. Y. Kondr. et Elix) S. Y. Kondr., L. Lőkös et J.-S. Hur, Mikhtomia gordejevii (Tomin) S. Y. Kondr., Kärnefelt, Elix, A. Thell, J. Kim, A. S. Kondratiuk et J.-S. Hur, Olegblumia demissa (Flot.) S. Y. Kondr., L. Lőkös, J. Kim, A. S. Kondratiuk, S.-O. Oh et J.-S. Hur and Pachypeltis intrudens (H. Magn.) Søchting, Frödén et Arup, as well as the genus Megaspora are reported as new for the Indian lichen biota.

Out of the eight lichenogeographical regions of India, the Western Himalayas show the maximum diversity of Teloschistaceae members represented with 110 species followed by the Central Indian region with 38 species. The lichen genus Caloplaca is represented with 50 species in the country followed by Athallia and Rusavskia with 6 species each. The saxicolous taxa exhibit dominance with 65 species whereas the corticolous and terricolous taxa are represented by 48 and 9 species, respectively. Among the different states of India, Uttarakhand showed the maximum diversity represented by 54 species followed by the state of Jammu \& Kashmir with 37 species, whereas the Jharkhand and Meghalaya states are represented only by the occurrence of a single species each. A key to the genera and species together with the description, basionyms and synonyms of each species are provided.

Key words: Caloplaca, diversity, Huriella, Lecanoromycetes, Megaspora, Mikhtomia, Neobrownliella, Olegblumia, Opeltia, Oxneriopsis, Pachypeltis, Squamulea, Teloschistales, Upretia 


\section{INTRODUCTION}

The lichen family Teloschistaceae is characterised by the presence of parietin as a major secondary product which imparts yellowish orange colour to the thallus and apothecia, polarilocular ascospores and Teloschistes-type of ascus. The character of the ascospores has always been important in the delimitation of the species, especially in the genus Caloplaca (Alon and Galun 1971, Kärnefelt 1989, Kondratyuk and Poelt 1997, Magnusson 1940, 1944, Poelt and Hinteregger 1993).

Awasthi $(1988,1991)$ enumerated 36 species belonging to two genera of Teloschistaceae from India. Joshi (2008) reported 83 species of teloschistoid taxa belonging to six genera from India. However, Singh and Sinha (2010) included Caloplaca aractina, C. aurantia, C. brebissonii, C. cirrochroa, C. diphyodes, C. encephalarti, C. festivella, C. fulvolutea, C. haematites, C. handelii, C. homologa, C. insularis, C. leptopisma, C. leptozona, C. pellodella, C. subdolosa in the checklist of lichens from India and reported 75 species of this family.

In recent years the advanced use of molecular characters has resulted in major taxonomic changes in the Teloschistaceae and resulted in the segregation of the family into four subfamilies - Brownlielloideae, Caloplacoideae, Teloschistoideae, and Xanthorioideae (Arup et al. 2013, Gaya et al. 2012, Kondratyuk et al. 2015d). Based on a study of three-gene phylogeny (nrITS1/ITS2, $28 \mathrm{~S} \mathrm{nLSU}$, and $12 \mathrm{~S} \mathrm{mtSSU}$ ), the number of genera recognised then increased from 10 to 39 (Arup et al. 2013, Kärnefelt 1989) and presently to 108 (Arup et al. 2013, Fedorenko et al. 2012, Kondratyuk et al. 2013a, 2014a, b, c, 2015a, b, c, e, 2016, 2017a, 2018a, b, c, 2019b, 2020b, Søchting et al. 2014a, b). Genera of the four subfamilies of the Teloschistaceae hitherto confirmed by three-gene phylogeny are listed in Table 1. Out of the so far known 108 genera of the family Teloschistaceae, India is represented by 36 genera such as Amundsenia, Athallia, Blastenia, Calogaya, Caloplaca, Flavoplaca, Fulgogasparrea, Gallowayella, Golubkovaea, Huneckia, Huriella, Ioplaca, Klauderuiella, Laundonia, Lazarenkoiopsis, Leproplaca, Massjukiella, Mikhtomia, Neobrownliella, Olegblumia, Opeltia, Oxneria, Oxneriopsis, Pachypeltis, Polycauliona, Pyrenodesmia, Rufoplaca, Rusavskia, Scythioria, Squamulea, Teloschistes, Upretia, Wetmoreana, Xanthaptychia, Xanthoria and Zeroviella.

Caloplaca, the largest genus within the family Teloschistaceae, has been split into 20 genera (Arup et al. 2013, Kondratyuk et al. 2015e, 2018a, 2020b) and new species are continuously being added in the genus. Joshi et al. (2012, 2014) described Caloplaca gyrophorica and Caloplaca indica from India. Upretia was recently described as a new genus in Teloschistaceae from India (Kondratyuk et al. 2018a) and two new species, i.e. Ioplaca rinodinoides and Rusavskia indochinensis, were described from India too (Kondratyuk et al. 2020a).

In the present enumeration, an updated list of 115 species of Teloschistaceae from India is presented together with keys to genera and species. Brief 


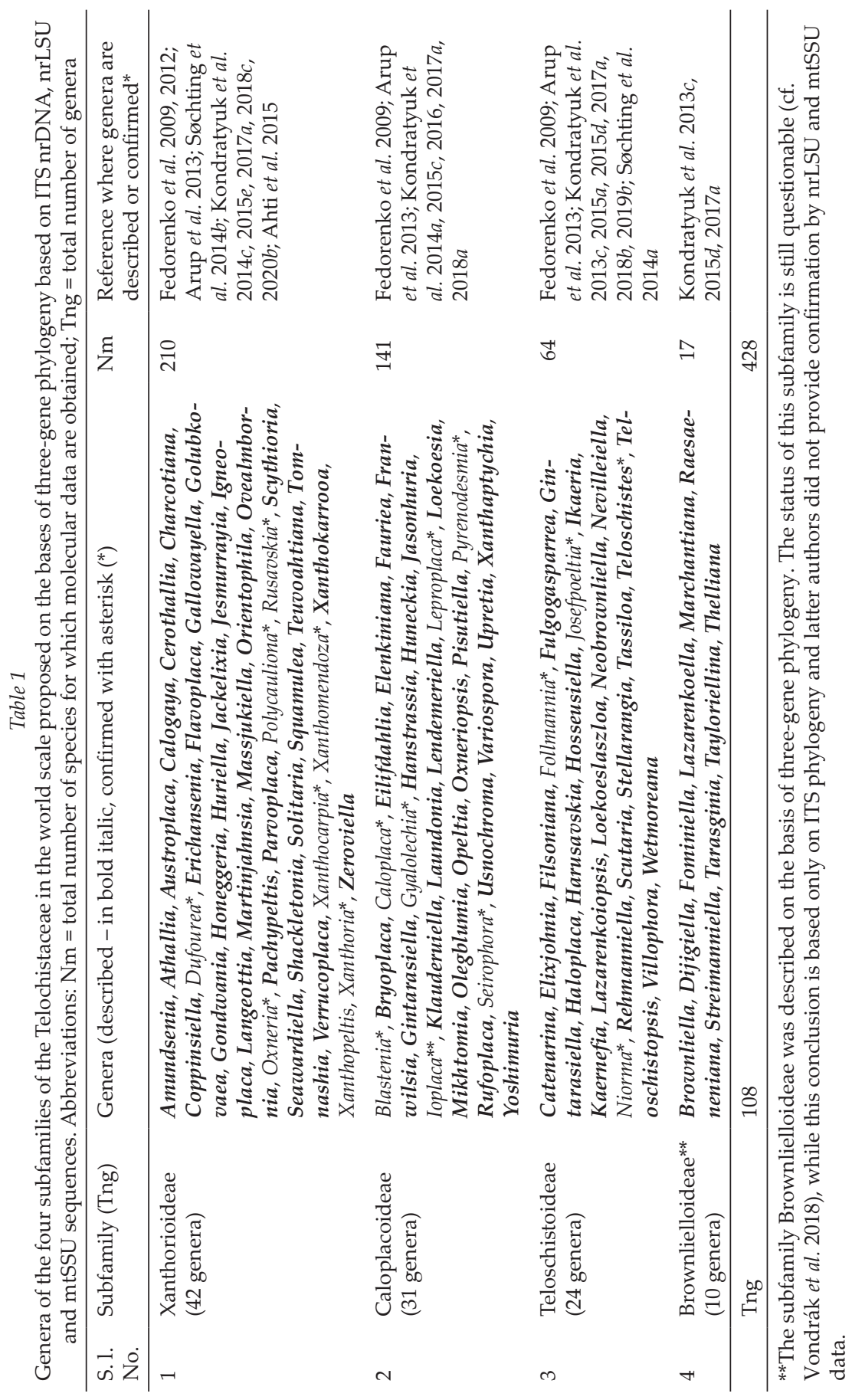




\section{descriptions and distributions of all taxa of Teloschistaceae including three species new for science are provided.}

Table 2

List of Teloschistacean taxa described and hitherto known only from India along with publishing year and their distribution. Abbreviations: $\mathrm{YP}=$ year of publication, $\mathrm{PP}=$ present paper

\begin{tabular}{|c|c|c|c|}
\hline S1.N & Teloschistacean taxa & $\mathrm{YP}$ & State \\
\hline 1 & Caloplaca abuensis Joshi et Upreti & 2008 & Rajasthan and Uttarakhand \\
\hline 2 & Caloplaca encephalartii (Kremp.) Zahlbr. & 1867 & West Bengal \\
\hline 3 & $\begin{array}{l}\text { Caloplaca gyrophorica Jagadeesh, Joshi et G. } \\
\text { P. Sinha }\end{array}$ & 2012 & West Bengal \\
\hline 4 & Caloplaca himalayana Joshi et Upreti & 2009 & $\begin{array}{l}\text { Himachal Pradesh and } \\
\text { Jammu \& Kashmir }\end{array}$ \\
\hline 5 & Caloplaca indica Y. Joshi, Jagadeesh et Sinha & 2014 & Arunachal Pradesh \& West Bengal \\
\hline 6 & Caloplaca jatolensis Joshi et Upreti & 2008 & Uttarakhand \\
\hline 7 & Caloplaca kashmirensis Joshi et Upreti & 2008 & Jammu \& Kashmir \\
\hline 8 & Caloplaca orissensis (Räsänen) D. D. Awasthi & 1950 & Orissa \\
\hline 9 & Caloplaca pseudisteroides Joshi et Upreti & 2008 & Madhya Pradesh \\
\hline 10 & $\begin{array}{l}\text { Caloplaca rajasthanica S. Y. Kondr., Upreti } \\
\text { et G. P. Sinha }\end{array}$ & PP & Rajasthan \\
\hline 11 & Caloplaca subbassiae Joshi et Upreti & 2018 & Madhya Pradesh and Uttarakhand \\
\hline 12 & Caloplaca subleptozona Joshi et Upreti & 2008 & $\begin{array}{l}\text { Himachal Pradesh, Rajasthan } \\
\text { and Uttarakhand }\end{array}$ \\
\hline 13 & Caloplaca tropica Joshi et Upreti & 2007 & Madhya Pradesh and Uttar Pradesh \\
\hline 14 & $\begin{array}{l}\text { Fulgogasparrea awasthii (Joshi et Upreti) } \\
\text { S. Y. Kondr., Upreti et A. Thell }\end{array}$ & 2007 & Madhya Pradesh and Rajasthan \\
\hline 15 & Gallowayella awasthiana S. Y. Kondr. et Upreti & 2018 & Uttarakhand and Jammu \& Kashmir \\
\hline 16 & $\begin{array}{l}\text { Huriella upretiana S. Y. Kondr., G. K. Mishra, } \\
\text { Nayaka et A. Thell }\end{array}$ & PP & Madhya Pradesh \\
\hline 17 & $\begin{array}{l}\text { Ioplaca rinodinoides S. Y. Kondr., K. K. Ingle, } \\
\text { D. K. Upreti et S. Nayaka }\end{array}$ & 2020 & Nagaland \\
\hline 18 & $\begin{array}{l}\text { Megaspora subpoliotera (Joshi et Upreti) } \\
\text { S. Y. Kondr., Upreti et A. Thell }\end{array}$ & 2008 & $\begin{array}{l}\text { Madhya Pradesh, Maharashtra, } \\
\text { Orissa and Uttar Pradesh }\end{array}$ \\
\hline 19 & Rusavskia indica S. Y. Kondr. et Upreti & 2017 & $\begin{array}{l}\text { Andaman Islands, Jammu } \\
\text { and Kashmir, Himachal Pradesh } \\
\text { and Uttarakhand }\end{array}$ \\
\hline 20 & $\begin{array}{l}\text { Rusavskia indochinensis S. Y. Kondr., } \\
\text { G. K. Mishra, S. Nayaka et D. K. Upreti }\end{array}$ & 2020 & Uttarakhand \\
\hline 21 & $\begin{array}{l}\text { Rusavskia upretii S. Y. Kondr., G. K. Mishra } \\
\text { et S. Nayaka }\end{array}$ & 2017 & Uttarakhand \\
\hline 22 & $\begin{array}{l}\text { Squamulea uttarkashiana S. Y. Kondr., Upreti, } \\
\text { Nayaka et A. Thell }\end{array}$ & PP & Uttarakhand \\
\hline 23 & $\begin{array}{l}\text { Upretia amarkantakana (Joshi et Upreti) } \\
\text { S. Y. Kondr. et A. Thell }\end{array}$ & 2018 & Madhya Pradesh \\
\hline
\end{tabular}




\section{MATERIAL AND METHODS}

The present study is based on recently collected and preserved lichen specimens in the herbarium of the CSIR-National Botanical Research Institute, Lucknow (LWG), the personal herbarium of Dr Awasthi (LWG-AWAS), Lucknow University lichen herbarium (LWG-LWU), Botanical Survey of India, Ajrekar Mycological Herbarium (AMH), MS Swaminathan Research Foundation (MSSRF), Central Regional Circle, Allahabad (BSA), Eastern Regional Centre of Botanical Survey of India, Meghalaya, Shillong (ASSAM), and published literature. The specimens were examined morphologically, anatomically, and chemically. Micrographs were prepared by an Olympus E450 camera (with Quick Photo Camera 2.3 software) with an Olympus SZX9 stereomicroscope. Thin hand-cut sections of apothecia and thallus were mounted in tap water, cotton blue and $5 \% \mathrm{KOH}$ and observed under a compound microscope (Nikon Eclipse E200; Nikon, Tokyo, Japan, and Zeiss Scope, A1; Carl Zeiss, Oberkochen, Germany equipped with digital camera AxioCam ERc 5s). For chemical spot tests the routine reagents of $\mathrm{K}, \mathrm{C}$ and $\mathrm{P}$ were used. TLC was performed in solvent system A (toluene: 1, 4-dioxane: acetic acid 180: 60: $8 \mathrm{ml}$ ), following the technique of White and James (1985) and Orange et al. (2001). The identifications of specimens were based on morphological anatomical, chemically and based on published literature of Joshi and Upreti (2007a, b), Arup et al. (2013) and Kondratyuk et al. (2013a, 2014a, b, 2015a, b, c, d, e). Species of the family which were described and are hitherto known only from India are listed in Table 2, specimens newly included in the molecular phylogeny are listed in Table 3.

The molecular studies were carried out in Lund University, Biological Museum, Sweden and in the Korean Lichen Research Institute, Sunchon National University, South Korea (KoLRI). For DNA extraction the method proposed by Ekman (1999) was used and extracted DNA was purified by the DNeasy Plant Mini Kit (QIAGEN, Germany). The internal transcribed spacer (ITSnrITS1/ITS2), 5.8S subunit (ITS) and the nuclear ribosomal RNA gene regions were amplified using the primers ITS1F and ITS4 (Gardes and Bruns 1993, White et al. 1990). Primer LR5 used for the 28S LSU (Vilgalys and Hester 1990) and the primers mtSSU1-mtSSU3R and mtSSU2R are used for the 28S LSU (Fedorenko et al. 2012, Lohtander et al. 2002). The Takara JP/TP600 PCR machine was applied in amplification of DNA. One initial cycle of $5 \mathrm{~min}$ at $94^{\circ} \mathrm{C}$ was followed by 30 cycles of the following steps: 30 seconds at $94^{\circ} \mathrm{C}, 39$ seconds at $57^{\circ} \mathrm{C}$ and $1 \mathrm{~min}$ at $72{ }^{\circ} \mathrm{C}$. Amplifications were ended with a final cycle at $72{ }^{\circ} \mathrm{C}$ for $10 \mathrm{~min}$. The similar PCR program was used for all loci studied. The sequencing was carried out using the fluorescent marker Big Dye and an ABI 3730xl sequencing machine (Applied Biosystems, Carlsbad, CA, USA) at GenoTech Corporation, Daejeon, South Korea.

The agreement sequence was aligned with all related species sequences retrieved from the GenBank database. Sequence alignment was conducted in BioEdit and a phylogenetic tree was generated by the maximum parsimony (MP), minimum evolution (ME), and maximum likelihood (ML) analysis methods. Analyses were conducted using PAUP $4.0 \mathrm{~b} 10$ on a Macintosh platform (Swofford 2003) and in Mega 5.0 (Tamura et al. 2011) with the number of bootstrap trials set to 1,000 .

\section{RESULTS AND DISCUSSION}

The Teloschistaceae in India is represented by 115 species belonging to 36 genera and four subfamilies. Among the genera, Caloplaca includes 50 species followed by Athallia (6 spp.), Rusavskia (6 spp.), Squamulea (4 spp.), Calogaya 


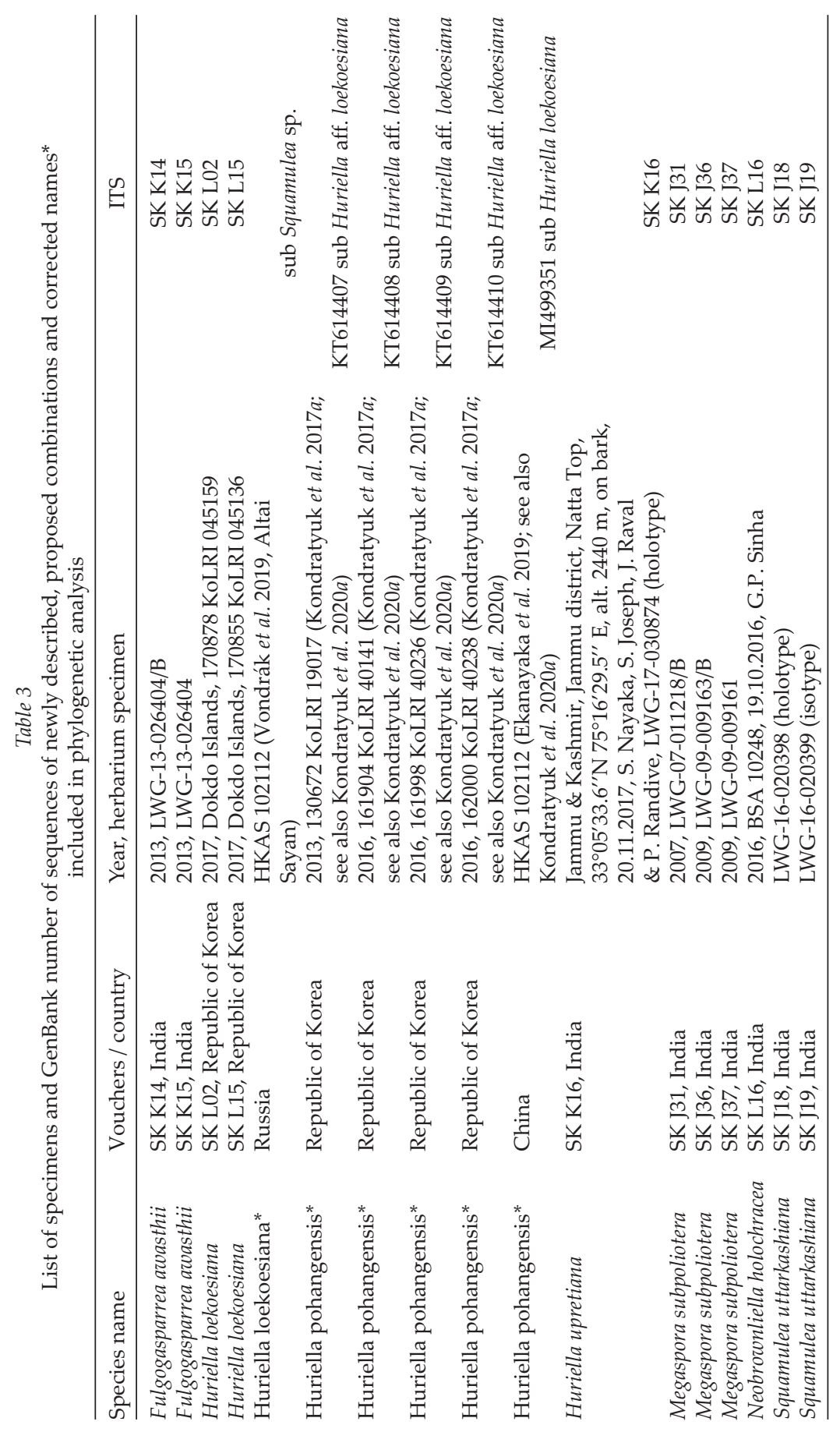


(3 spp.), Flavoplaca (3 spp.), Ioplaca (3 spp.), and Leproplaca (3 spp.). Among 115 species 82 species exhibited crustose to squamulose habit and a single species of fruticose growth forms (Teloschistes flavicans) is recorded. 65 species were found to grow on rocks (saxicolous) followed by 48 species, which grow on tree trunks, branches and twigs (corticolous) while 9 species either grow directly on soil or on soil over rocks or associated with mosses. The genera Golubkovaea, Ioplaca and Upretia occur on calcareous rock while the genera Mikhtomia, Opeltia, Scythioria, Massjukiella and Teloschistes species are known only on trees. The species of the genera Calogaya, Caloplaca, Laundonia, and Rusavskia grow on both bark and rock substrate.

Among different states of India, Uttarakhand showed the maximum diversity of Teloschistaceae representing 54 species, while Jammu \& Kashmir and Madhya Pradesh represented 37 and 26 species, respectively. The states of Jharkhand and Meghalaya, poorly explored for lichens, exhibit occurrence of a single species each of the teloschistoid lichens. Among the 115 species known to India, 23 species are supposedly endemic to the country with their maximum representation of eight species in Uttarakhand followed by Madhya Pradesh with seven species.

Oxneriopsis bassiae, Opeltia flavorubescens, Caloplaca cupulifera, C. subdolosa, Neobrownliella cinnabarina, Laundonia flavovirescens and Calogaya decipiens are the most common and widely distributed species in the whole country.

The species of the Teloschistaceae mainly occur in temperate regions, but there are exceptions in such a diverse group and such a vast country like India. In tropical parts of India Oxneriopsis bassiae is the most common species on trees such as Mangifera indica, Shorea robusta and Mallotus philippensis, whereas Caloplaca cupulifera, Squamulea subsoluta, S. uttarkashiana and Caloplaca tropica occur on exposed rocks in the region. The temperate zone is also rich in diversity of corticolous species which host many prominent species such as Amundsenia approximata, Leproplaca chrysodeta, Scythioria phlogina on trees like Acer, Aesculus, Celtis, Pinus, Quercus and Taxus. Others like Flavoplaca citrina, F. flavocitrina, Leproplaca obliterans, Squamulea squamosa and Rusavskia granulifera occur on rocks. Other species found in the temperate zone are Caloplaca stillicidiorum, C. heterospora, C. maura, Teloschistes flavicans and Xanthoria parietina, found abundantly on exposed rocks or in moist humid places covered under trees or near the streams.

In the areas above an altitude of 3,000 $\mathrm{m}$ in alpine regions trees are replaced by small shrubs and grassland and hence here the lichens mostly grow on rocks, soil and branches of shrubs. Common saxicolous species in the alpine region are Caloplaca stillicidiorum, Rufoplaca arenaria, Ioplaca pindarensis, I. rinodinoides and some xanthorioid lichens only known from higher elevations in the Indian Himalayan region. 
In the present study Caloplaca elegantissima (Nyl.) Zahlbr. (= Caloplaca indurata V. Wirth et Vězda), described by Sen (2014) from West Bengal, and Caloplaca trilocularis Zahlbr., reported (Kholia et al. 2012) from Uttarakhand, are excluded. C. elegantissima (Nyl.) Zahlbr. is known mainly from Namibia and South Africa (Arup et al. 2013), while C. trilocularis Zahlbr. is a printing error for C. triloculans Zahlbr. Furthermore, Caloplaca rajasthanica, Huriella upretiana and Squamulea uttarkashiana are described as new species. Lazarenkoiopsis ussuriensis, Mikhtomia gordejevii, Olegblumia demissa and Pachypeltis intrudens are described as new record for the country and seven new combinations, i.e. Fulgogasparrea awasthii, Neobrownliella cinnabarina, Neobrownliella holochracea, Opeltia flavorubescens, Oxneriopsis bassiae, Upretia hueana and Megaspora subpoliotera for Indian lichens are presented here in this paper.

Key to genera of Teloschistaceae occurring in India

1 Thallus leprose, crustose or squamulose

- Thallus foliose, fruticose or subfruticose or foliose

2 Thallus completely leprose, sorediate, apothecia absent

Leproplaca

- Thallus crustose, areolate, squamulose or lobulate

3 Lower cortical layer present, well developed

Golubkovaea

- Lower cortical layer absent

4 Apothecia immersed, cryptolecanorine Ioplaca

- Apothecia zeorine

5 Thallus isidiate or sorediate

- Thallus lacking soredia and isidia 27

6 Thallus isidiate 7

- Thallus sorediate

7 Thallus with anthraquinones (fragilin dominated)

Oxneriopsis

- Thallus without anthraquinones

8 Apothecia biatorine, disc rusty orange

Blastenia

- Apothecia lecanorine, disc yellow to dark orange

Caloplaca 
9 Thallus poorly developed or lacking

Athallia

- Thallus well developed

10 Thallus film-like, corticolous, greenish-yellowish continuous or crustose and well contrasting to bright yellowish subconvex soredious mass Lazarenkoiopsis

- Thallus and soredia otherwise

11 Thallus on various substrates - rock, bark, soil and along with mosses, dark greyish to whitish, apothecial disc yellow to orange

Caloplaca

- Thallus saxicolous or corticolous, apothecial disc and thallus various shades of colours

12 Thallus saxicolous

- Thallus corticolous

13 Thallus areolate to somewhat squamulose and sorediate

Flavoplaca

- Thallus different forms and partly sorediate

14 Thallus orange colour, apothecia sparse, disc orange

Amundsenia

- Thallus grey-brownish to yellow-orange, apothecia clustered, disc different colour

15 Thallus partly pruinose, grey to brownish grey upper surface Upretia

- Thallus not pruinose, dark yellowish to orange-yellow upper surface Pachypeltis

16 Thallus grey colour, without anthraquinones

- Thallus different shades of colour and with or without anthraquinones 19

17 Apothecia zeorine, conidia narrowly to broadly ellipsoid or citriform Scythioria

- Apothecia zeorine to lecanorine, conidia bacilliform

18 Ascospores with thickened end walls

Huneckia

- Ascospores without thickened end walls

Caloplaca

19 Thallus continuous to areolate, cortical layer paraplectenchymatous, apothecia immersed to biatorine

- Thallus areoles flat to convex and cortex different type; apothecia various 
20 Thallus yellow to reddish orange or pink, apothecia immersed to biatorine, true exciple poorly developed

Neobrownliella

- Thallus pale yellow or orange to greenish grey, apothecia biatorine, true exciple Blastenia-type

21 Apothecia yellow-orange to brown-orange with distinct yellowish thalline margin

Opeltia

- $\quad$ Apothecia with reddish or rusty shade, orange-reddish to rusty orange with dark orange own margin

Mikhtomia

22 Thallus distinct lobulate to squamulose, after forming asexual propagules

- Thallus lobulate or not, fruiting bodies present or absent

23 Soralia terminal, soredious mass more or less distinct

Wetmoreana

- Soralia small, laminal, soredious mass somewhat isidious and often uplifted

Fulgogasparrea

24 Ascospores variable, polardiblastic with short or long septum, wider at the middle resulting a citriform shape, sand-glass type Klauderuiella

- Ascospores polardiblastic with short or long septum and different shape and type

25 Apothecia biatorine to zeorine, disc orange to reddish brown Rufoplaca

- Apothecia zeorine or sometime biatorine, disc different colour 26

26 Thallus greyish, grey, apothecia zeorine to biatorine, pycnidia present or absent

Pyrenodesmia

- $\quad$ Thallus yellowish grey to orange, apothecia lecanorine or biatorine, pycnidia absent

Laundonia

27 Thallus distinctly lobate at margin $\quad 28$

- Thallus indistinctly lobate at margin, areolate to squamulose 29

28 Thallus distinctly rosette-like, upper surface brownish to grey, apothecia and pycnidia unknown Olegblumia

- Thallus lobulate, upper surface yellowish to orange, apothecia zeorine and ellipsoid to bacilliform conidia Calogaya

29 Thallus lacking anthraquinone, grey in colour Blastenia

- Thallus with anthraquinone, various shades of yellow orange $\quad 30$ 
30 Thallus areolate and having longer than $12 \mu \mathrm{m}$ and wider than $7 \mu \mathrm{m}$ ascospores

Huriella

- Thallus squamulose and have smaller ascospores

Squamulea

31 Thallus subfruticose to fruticose

- Thallus foliose

32 Thallus subfruticose, smaller in size (up to $0.5-2 \mathrm{~mm}$ in height); apothecia zeorine; disc yellow to orange; conidia narrowly to broadly ellipsoid or citriform

Polycauliona

- Thallus distinctly fruticose; apothecia lecanorine to zeorine; disc yellow to brownish orange; conidia bacilliform, bifusiform or narrowly ellipsoid

Teloschistes

33 Thallus is rosette-forming or cushion-shaped, lobes usually very small, up to $0.2 \mathrm{~mm}$ wide, dorsiventral to radially arranged Massjukiella

- Thallus not rosette-forming, lobes larger, from $0.3 \mathrm{~mm}$ to $5(-7) \mathrm{mm}$ wide, dorsiventral to slightly raised

34 Thallus pronounced convex, upper and lower cortex scleroplectenchymatous, lobes usually hollow; conidia bacilliform only

Rusavskia

- Thallus flattened, lobes distinctly dorsiventral, cortex of different type; conidia \pm bacilliform or ellipsoid

35 Lower cortical layer absent, having scleroplectenchymatous tissue in thallus and cortex of thalline margin of apothecia; thallus whitish grey

Xanthaptychia

- Both upper and lower cortical layer well developed

36 Hapters present, rhizines absent

Xanthoria

- Hapters absent, true rhizines present or attachment organs lacking 37

37 True exciple pseudoprosoplectenchymatous (sensu Kondratyuk and Kärnefelt 1997); conidia broadly bacilliform Gallowayella

- True exciple scleroplectenchymatous; conidia narrowly elongated bacilliform

38 Thallus saxicolous or muscicolous, usually well-developed numerous pseudocyphellae, rhizines absent

Zeroviella

- Thallus corticolous, pseudocyphellae absent, rhizines present Oxneria 


\section{Taxonomy}

\section{Amundsenia Søchting, Garrido-Ben., Arup et Frödén}

Type: Amundsenia austrocontinentalis Garrido-Benavent, Søchting, Pérez-Ortega et Seppelt

Two species of the genus Amundsenia are known in the world of which one is reported from India (Søchting et al. 2014b).

Amundsenia approximata (Lynge) Søchting, Arup et Frödén, Lichenologist 46(6): 774 (2014). - The species is characterised by greenish yellow, areolate to squamulose thallus, vivid orange apothecial disc, smooth to crenulate thalline margin and bigger ascospores with reduced septa (Joshi 2008). Chemistry: Thallus, apothecial disc and epihymenium $\mathrm{K}+$ purple, $\mathrm{KC}-, \mathrm{C}-, \mathrm{Pd}-$ : parietin present in TLC. Ecology and distribution: This saxicolous species grows between altitudes of 2,100-3,200 $\mathrm{m}$ and has restricted distribution in Uttarakhand.

Representative specimens examined: Uttarakhand, Bageshwar district, Khati, alt. 2,210 m, on rock, 10.05.2007, S. Joshi \& Y. Joshi, LWG-07-008915; Nainital district, Draw Paul area, alt. 2,000 m, on rock, 07.12.2009, H. Kholia, LWG-09-014806; Pithoragarh district, Naher Devi to Mapang, Milam Glacier, alt. 2,705-3,160 m, on rock, 19.10.2007, S. Joshi, LWG-07-010498.

\section{Athallia Arup, Frödén et Søchting}

Type: Athallia holocarpa (Hoffm.) Arup, Frödén et Søchting

The genus Athallia includes nine species in the world, of which six are known from India (Arup et al. 2013).

1 Thallus saxicolous

- Thallus corticolous

2 Ascospores 6-8(-9) $\mu \mathrm{m}$ wide

A. holocarpa

- $\quad$ Ascospores 4.5-6 $\mu \mathrm{m}$ wide

A. vitellinula

3 Asci usually 12-16-spored

A. cerinella

- Asci 8-spored

4 Thallus golden yellow, continuous to areolate, hypothecium without oil globules

A. alnetorum

- Thallus grey to greyish white

5 Apothecia small, $0.1-0.5 \mathrm{~mm}$ in diam., parathecium wide $A$. cerinelloides

- $\quad$ Apothecia larger, $0.5-1.2 \mathrm{~mm}$ in diam., parathecium narrow and strongly suppressed

A. pyracea 
Athallia alnetorum (Giralt, Nimis et Poelt) Arup, Frödén et Søchting, Nordic J. Bot. 31(1): 36 (2013). - This species is characterised by numerous apothecia, ellipsoid to broadly ellipsoid, ovoid to globose or mischoblastia type ascospores, 11-12 × 5-7 $\mu \mathrm{m}$ (Awasthi 1991). Chemistry: Thallus, apothecial disc and epihymenium $\mathrm{K}+$ purple, $\mathrm{KC}-, \mathrm{C}-, \mathrm{Pd}-$ : parietin present in TLC. Ecology and distribution: Corticolous species growing on bark of Cedrus and Abies between elevations of 2,000-2,800 m in Himachal Pradesh.

Representative specimens examined: Himachal Pradesh, Chamba district, Chamba, around the Joth, alt. 2,000-2,350 m, on Cedrus bark, 17.05.2001, D. K. Upreti \& S. Nayaka, LWG-01-75556. - Uttarakhand, Uttarkashi district, Govind Wildlife Sanctuary, en route to Devkyara, near bridge of Supin and Obra Ghat, alt. 2,065 m, on rock, 20.10.2016, S. Nayaka, LWG-16-030814.

Athallia cerinella (Nyl.) Arup, Frödén et Søchting, Nordic J. Bot. 31(1): 36 (2013). - Thallus poorly developed, apothecia densely aggregated, firmly appressed, $c a 0.1-0.5 \mathrm{~mm}$ in diam.; asci 12-16-spored, ascospores ellipsoid to broadly ellipsoid, 8.5-13 $\times$ 5-7 $\mu \mathrm{m}$, septa 3-5 $\mu \mathrm{m}$ wide. Chemistry: Thallus $\mathrm{K}-, \mathrm{KC}-, \mathrm{C}-, \mathrm{Pd}-$ : apothecial disc and epihymenium $\mathrm{K}+$ purple: parietin present in TLC. Ecology and distribution: It grows on fallen twigs in alpine regions of Uttarakhand at an elevation of 3,710 $\mathrm{m}$ in association with Caloplaca cerina and Candelariella vitellina.

Representative specimen examined: Uttarakhand, Uttarkashi district, Gomukh area, right bank, alt. 3,810 m, on twigs, 03.07.1976, D. D. Awasthi \& S. R. Singh, LWG-AWAS-8413.

Athallia cerinelloides (Erichsen) Arup, Frödén et Søchting, Nordic J. Bot. 31(1): 36 (2013). - This species is characterised by greyish white thallus with very small yellow to yellow-orange apothecia having concolorous or paler proper margin (Joshi 2008). Chemistry: Thallus K-, KC-, C-, Pd-: apothecial disc and epihymenium K+ purple: parietin present in TLC. Ecology and distribution: Corticolous species, distributed between altitudes of 1,900-2,700 m in temperate regions of Jammu \& Kashmir, Mizorum and Uttarakhand states.

Representative specimens examined: Jammu \& Kashmir, Anantnag district, Pahalgam Baltal, alt. 2,700 m, on bark, 29.08.1982, A. Singh \& D. K. Upreti, LWG-13939. - Uttarakhand, Chamoli district, Malari area, alt. 3,300 m, on coniferous bark, 23.09.2006, S. Rawat, LWG-06-52214.

Athallia holocarpa (Hoffm.) Arup, Frödén et Søchting, Nordic J. Bot. 31(1): 36 (2013). - Thallus crustose, indistinct or badly developed, apothecia lecanorine to zeorine, disc yellowish to slightly reddish orange; ascospores 9-16 $\times 6-8 \mu \mathrm{m}$, septum to $2-5 \mu \mathrm{m}$ wide. Chemistry: Thallus, apothecial disc and epihymenium $\mathrm{K}+$ purple, $\mathrm{KC}-, \mathrm{C}-$, $\mathrm{Pd}-$ : parietin present in TLC. Ecology and distribution: Saxicolous species growing along with species of Aspicilia, Caloplaca, Porpidia, Rusavskia, Staurothele and Verrucaria in temperate to subalpine region of Uttarakhand.

Representative specimens examined: Uttarakhand, Bageshwar district, Pindari Glacier; Khati, near temple, alt. 2,210 m, on rock, 11.05.2007, Y. Joshi \& S. Joshi LWG-07-010307; 
Pithoragarh district, Munsiyari, alt. 2,500 m, on rock, 16.11.2006, Y. Joshi \& R. Bajpai, LWG06-006234; Uttarkashi district, Gomukh area, right bank, alt. 3,840 m, on rock, 02.07.1976, D. D. Awasthi \& S. R. Singh, LWG-AWAS-8385.

Athallia pyracea (Ach.) Arup, Frödén et Søchting, Nordic J. Bot. 31(1): 36 (2013). - It is characterised by scurfy-furfuraceous or finely granular to endoxylic whitish grey thallus with numerous conspicuous yellow to yellow-orange apothecial disc surrounded by concolorous proper margin (Joshi 2008). Chemistry: Thallus $\mathrm{K}-, \mathrm{KC}-, \mathrm{C}-$, $\mathrm{Pd}-$; apothecial disc and epihymenium $\mathrm{K}+$ purple, $\mathrm{KC}-, \mathrm{C}-, \mathrm{Pd}-$ : emodin, parietin, xanthorin, fallacinal present in TLC. Ecology and distribution: Corticolous species, distributed between the altitudes of 1,650-2,100 m in Himachal Pradesh, Jammu \& Kashmir and Uttarakhand.

Representative specimens examined: Uttarakhand, Champawat district, Dividhura, alt. 1,700 m, on Quercus bark, 28.11.2010, G. K. Mishra, LWG-10-015381; Near Guest House Champawat, alt. 1,615 m, on bark, 27.11.2010, G. K. Mishra, LWG-10-015377.

Athallia vitellinula (Nyl.) Arup, Frödén et Søchting, Nordic J. Bot. 31(1): 37 (2013). - Apothecia yellowish to orange, lecanorine, 0.3-1.5 mm diam., disc yellow, sessile, ascospores 9-11 × 4-7 $\mu \mathrm{m}$. Chemistry: Thallus $\mathrm{K}_{-}, \mathrm{KC}-, \mathrm{C}-$, $\mathrm{Pd}-$; apothecial disc and epihymenium $\mathrm{K}+$ purple: parietin present in TLC. Ecology and distribution: The species is only known to be corticolous and growing in tropical and temperate regions in Madhya Pradesh, Manipur, Tamil Nadu and Uttarakhand. Taxonomic notes: Previously, saxicolous specimens of Athallia holocarpa-pyracea complex were usually included in A. vitellinula. However, the type specimen of A. vitellinula is from bark of Alnus tree and differs in having narrower ascospores. All Indian specimens of this species need thorough revision.

Representative specimens examined: Uttarakhand, Chamoli district, Badrinath Mana village, on rocks, 21.06.2005, V. Shukla \& Y. Joshi, LWG-05-004945, LWG-05-004947, LWG-05-005262, LWG-05-005263; $0.5 \mathrm{~km}$ from Malari, on the way to Niti, alt. 3,086 m, on rock, 19.08.2007, D. K. Upreti \& S. Nayaka, LWG-07-011222.

\section{Blastenia A. Massal.}

Type: Blastenia ferruginea (Huds.) A. Massal.

Blastenia is a cosmopolitan genus represented by 10 species in the world (Arup et al. 2013), of which two species are known from India.

1 Thallus pale to dark grey, isidiate, apothecia absent

B. herbidella

- Thallus grey, isidia absent, apothecia present and ferrugineus

B. ferruginea

Blastenia ferruginea (Huds.) A. Massal., Atti Inst. Veneto Sci. Lett., ed Arti, Sér. 2, 3(3): 102 (1852). - The species is mainly characterised by grey 
thallus, ferrugineus apothecial disc lacking thalline margin, elongated hyphal cells in parathecium and amphithecium without algae (Joshi 2008). Chemistry: Thallus $\mathrm{K}-, \mathrm{KC}-, \mathrm{C}-, \mathrm{Pd}-$; apothecial disc and epihymenium $\mathrm{K}+$ purple: parietin present in TLC. Ecology and distribution: Corticolous species growing with Flavoplaca granulosa, Opeltia flavorubescens, Lecanora and Pertusaria spp. in tropical and temperate regions of Arunachal Pradesh, Himachal Pradesh, Karnataka, Maharashtra, Tamil Nadu and Uttarakhand.

Representative specimens examined: Himachal Pradesh, Kullu district, Great Himalayan National Park, Gusaini to Ropa, 1,700-1,800 m, on bark, 04.09.1999, D. K. Upreti, LWG-99-52618; Shimla district, Theog, $3 \mathrm{~km}$ towards Chailla, alt. 2,510 m, on Pinus, 09.05.2002, S. Nayaka \& R. Srivastava, LWG-02-79023. - Uttarakhand, Champawat district, 7 km from Mayawati Lohaghat, on bark, 29.10.2009, D. K. Upreti, LWG-09-012496; Near Guest House Champawat, alt. 1,600 m, on bark, 26.11.2010, G. K. Mishra, LWG-10-015224; Devidhura, alt. 1,750 m, on bark, 28.11.2010, G. K. Mishra, LWG-10-015379; Pithoragarh district, Barkot to Madkot, on bark, 01.11.2009, D. K. Upreti \& G. K. Mishra, LWG-09012129, LWG-09-012403. - West Bengal, Sundarbans Biosphere Reserve, Saptamukhi forest, on Excoecaria agallocha bark, 18.03.2002, M. Jagadeesh Ram, ASSAM-12217.

Blastenia herbidella (Arnold) Servít, Hedwigia 74(2): 148 (1934). - The species is characterised by \pm continuous, pale to dark grey thallus, rarely in part with a green or yellowish orange tinge, isidia numerous and crowded, simple or coralloid, whitish grey with brownish tips (Joshi 2008). Chemistry: Thallus and isidia $\mathrm{K} \pm, \mathrm{KC}-, \mathrm{C}-, \mathrm{Pd}-$ : parietin present in TLC. Ecology and distribution: Corticolous species with restricted distribution in Odisha (Orissa).

Representative specimens examined: Orissa, Ganjam district, on the way to Seranga, on bark, 03.03.1986, D. D. Awasthi, G. Awasthi, R. Mathur \& P. Srivastava, LWG-LWU-86-140.

\section{Calogaya Arup, Frödén et Søchting}

Type: Caloplaca biatorina (A. Massal.) Arup, Frödén et Søchting

The genus Calogaya is represented by 16 species in the world, of which three species are known from India (Vondrák et al. 2018).

1 Thallus yellow-orange, placodioid, soredia present, apothecial disc darker orange than thallus, flat

C. decipiens

- Thallus yellowish orange, lobulate, soredia absent, apothecial disc deep red to reddish brown or dark orange, flat to subconcave

2 It grows in cold desert area at high elevation, apothecial disc deep red to reddish brown and the septa of this species is narrow and is $1 / 4$ of the length of the ascospore

C. biatorina

- It grows in temperate parts of the country, apothecial disc dark orange and having wider ascospore septa, at best, measuring of the length of the ascospore

C. saxicola 
Calogaya biatorina (A. Massal.) Arup, Frödén et Søchting, Nordic J. Bot. 31(1): 38 (2013). - The species is mainly characterised by yellowish orange lobate thallus, apothecia scattered, disc deep red to reddish brown, flat to subconvex, ascospores, broadly ellipsoid to subglobose to globose, 8-17 $\times$ 4-10 $\mu \mathrm{m}$ and narrow ascospore isthmus (Joshi 2008). Chemistry: Thallus and apothecial disc $\mathrm{K}+$ purple, $\mathrm{KC}-, \mathrm{C}-, \mathrm{Pd}-$ : parietin present in TLC. Ecology and distribution: Saxicolous species growing on calcareous and non-calcareous rocks in association with Acarospora, Aspicilia, Candelariella, Diploschistes, Lecanora and Rusavskia spp. between elevations of 3,000-3,800 m in Himachal Pradesh and Jammu \& Kashmir.

Representative specimens examined: Himachal Pradesh, Kangra district, Po village, on rock, 24.07.1952, O. A. Höeg, LWG-AWAS-1556; Kaze, alt. 3,600 m, on rock, 09.08.1952, O. A. Höeg, LWG-AWAS-1654; Pin river valley left bank, about 1 mile above Sillung village, alt. 3,600 m, on boulders, 31.07.1952, O. A. Höeg, LWG-AWAS-1590.

Calogaya decipiens (Arnold) Arup, Frödén et Søchting, Nordic J. Bot. 31(1): 38 (2013). - It is the most variable species characterised by a placodioid, uniformly orange-yellow, contiguous thallus with uniformly coloured \pm pruinose convex lobes which are broadened at the tips, bulbate areoles in the centre and soredia originating from underside of lobe tips (Joshi 2008). Chemistry: Thallus and soredia $\mathrm{K}+$ purple, $\mathrm{KC}-, \mathrm{C}-, \mathrm{Pd}-$ : parietin and unknown yellow-orange spot at Rf 6 present in TLC. Ecology and distribution: Saxicolous species growing on siliceous and non-calcareous rocks in temperate and tropical regions of Jammu \& Kashmir, Madhya Pradesh, Maharashtra, Rajasthan and Uttarakhand.

Representative specimens examined: Jammu \& Kashmir, Leh district, Rumtsey, alt. 4,900 m, on rocks, 05.08.2003, D. K. Upreti \& S. Chatterjee, LWG-03-001787. - Madhya Pradesh, Dhar district, Lat ki Masjid, on rocks, 19.01.2007, Y. Joshi \& R. Bajpai, LWG-07007414, LWG-07-007409. - Maharashtra, Pune city, in hill, opposite NCL, alt. $560 \mathrm{~m}$, on rock, 27.03.2005, S. Nayaka, LWG-05-001871. - Rajasthan, Sirohi district, Mt Abu, alt. 1,2001,300 m, on rocks, 15.09.1985, D. D. Awasthi \& G. Awasthi, LWG-LWU-85-39.

Calogaya saxicola (Hoffm.) Vondrák, Lichenologist 48(3): 178 (2016). This species is mainly characterised by yellowish orange lobate thallus having wide ascospore isthmus (Joshi 2008). Chemistry: Thallus, apothecial disc and epihymenium $\mathrm{K}+$ purple, $\mathrm{KC}-, \mathrm{C}-$, $\mathrm{Pd}-$ : parietin present in TLC. Ecology and distribution: Saxicolous species, distributed in temperate to subalpine regions of Himachal Pradesh, Jammu \& Kashmir, Madhya Pradesh and Uttarakhand.

Representative specimens examined: Himachal Pradesh, Kangra district, Pin valley, left bank, one mile above Sibung village, alt. 3,600 m, on rock, O. A. Höeg, LWGAWAS-1586. - Jammu \& Kashmir, Anantnag district, Phalgam, Baltal, alt. 2,700 m, on rock, 29.08.1982, A. Singh \& D. K. Upreti, LWG-13921. - Uttarakhand, Bageshwar district, near Phurkia bungalow, alt. 3,300 m, on vertical side of stone boulder, 10.06.1970, D. D. Awasthi, LWG-AWAS-7659, LWG-AWAS-7660; Chamoli district, $10 \mathrm{~km}$ from Gamsali, on the way to Niti, alt. 3,300 m, on rocks, 20.08.2007, D. K. Upreti \& S. Nayaka, LWG-07-011219. 


\section{Caloplaca Th. Fr.}

Type: Caloplaca cerina (Ehrh. ex Hedw.) Th. Fr.

More than 1,000 species of Caloplaca have been reported from all parts of the world (Søchting and Lutzoni 2003), while 50 species are widely distributed in subtropical and temperate regions of India (Joshi 2008, Singh and Sinha 2010 and in the present paper). Based on molecular data the position of only 7 species in the Caloplaca cerina (i.e. Caloplaca s. str.) branch is hitherto confirmed, while the other species are members of the other groups and their status within the Teloschistaceae is still waiting for confirmation with the application of molecular markers.

1 Thallus terricolous

- Thallus corticolous or saxicolous

2 Apothecial disc yellowish brown to orange, proper margin absent 3

- Apothecial disc orange brownish black to black, proper margin present 4

3 Disc yellow to olivaceous green, concave to flat

C. stillicidiorum

- Disc orange to brown, flat to convex or sometime pruinose

C. cerina var. muscorum

4 Thallus sorediate

C. heterospora

- Thallus without soredia

5 Thallus whitish grey, apothecial disc yellow, ascospores $14-21 \times 7-11 \mu \mathrm{m}$

C. fulvolutea

- Thallus grey, apothecial disc brownish to black, ascospores 12-18 $\times 6-10 \mu \mathrm{m}$

C. maura

6 Thallus corticolous

- Thallus saxicolous

7 Thallus sorediate or isidiate

- Thallus without soredia or isidia

8 Thallus isidiate

- Thallus sorediate

9 Thallus reddish orange, true isidia present

C. kashmirensis

- Thallus bright yellow, membranaceous at the beginning, isidia-like, more or less branched blastidia present

C. malaeensis 
10 Soredia medullary origin

C. phloginopsis

- $\quad$ Soredia arising marginally

11 Thallus dark, continuous, soralia isolated or often confluent, orange to reddish or brownish orange; apothecia brownish, poorly developed, fund in warm temperate climate

C. aureosora

- Thallus distinctly grey, corticolous, with numerous apothecia

C. atrosanguinea

12 Ascospores trilocular 13

- Ascospores polaribilocular 16

13 Ascospores 22-25 × 11-12 $\mu \mathrm{m}$ C. homologa

- Ascospores 8-20 × 6-11 $\mu \mathrm{m} \quad 14$

14 Disc yellowish to orange or dark yellow C. crocea

- Disc reddish to brown 15

15 Apothecial disc concave or sometime plane, thalline margin thick

C. triloculans

- $\quad$ Apothecial disc plane to concave, thalline margin thin C. jatolensis

16 Apothecial disc rust brownish to brown to black 17

- Apothecial disc different colour yellow-orange or pale reddish to reddish

17 Growing on small twigs in subalpine belt, apothecia of Lecanora subfusca$\begin{array}{ll}\text { type, very small } 0.2-0.3 \mathrm{~mm} \text { diam. } & C \text {. rinodinopsis }\end{array}$

- Growing on other substrata, apothecia usually larger and of another type

18 Apothecial disc plane to convex, ascospores 25-30 × 12-16 $\mu \mathrm{m}$

\section{C. brebissonii}

- Apothecial disc flat to subconvex, ascospores 9-11 × 4-7 $\mu \mathrm{m}$

\section{C. himalayana}

19 Thallus whitish grey to brownish, prothallus present or absent 20

- Thallus verrucose and yellowish to orange, prothallus bluish grey

C. haematites

20 Thallus UV+ yellow orange, amphithecium with pale brown crystals confined in the upper region, ascospores $20-25 \times 13-18 \mu \mathrm{m}$

C. indica 
- Thallus UV-, amphithecium without crystals, ascospores different size 21

21 Apothecia biatorine, disc yellow to brownish or pale reddish, margin excluded C.encephalarti

- Apothecia lecanorine or sometime subbiatorine, disc reddish to brownish

C. cerina

22 Thallus sorediate or isidiate 23

- Thallus without soredia or isidia 26

23 Thallus isidiate C. subbassiae

- Thallus sorediate 24

24 Thallus distinctly lobate at margin, centrally areolate $\quad$. cirrochroopsis

- Thallus without lobes or indistinct lobes 25

25 Thallus yellow to brownish yellow, soredia crateriform C. cupulifera

- Thallus grey to whitish grey to olivaceous brown C. abuensis

26 Thallus pale yellow to yellow-orange or brownish orange 27

- Thallus whitish-greyish to white or bluish grey, grey to olive 35

27 Thallus indistinct 28

- Thallus distinct $\quad 32$

28 Thallus poorly developed, parasite on saxicolous Aspicilia species

C. insularis

- Thallus usually well developed, not parasitic 29

29 Ascospores larger, 9-15 × 5-10 $\mu \mathrm{m} \quad 30$

- Ascospores smaller, 6-8 8 1-5 $\mu \mathrm{m} \quad$ C. fraudans

30 Apothecia biatorine, disc carneous brown, oil globules absent C. handelii

- Apothecia zeorine, disc yellow to orange to reddish orange, oil globules present

31 Apothecial disc round to \pm angular, yellow to orange to reddish orange, flat to convex, paraphyses simple to moniliform

C. lithophila

- Apothecial disc angular to \pm rounded, orange-brownish, flat to slightly concave, paraphyses furcate to anastomosed

C. pachycheila 
32 Thallus compact, rosette-like, continuous or areolate, with well distinct thinner peripheral zone and much thicker central portions

C. rajasthanica

- Thallus with another combination of characters

33 Thallus containing gyrophoric acid $(\mathrm{C}+\mathrm{red}, \mathrm{KC}+\mathrm{red})$

C. gyrophorica

- Thallus containing other lichen substance

34 Thallus distinctly squamulose

C. irrubescens

- Thallus crustose to areolate

C. ruderum

35 Thallus whitish grey to brown

C. subdolosa

- Thallus olivaceous grey or brownish grey

36 Thallus indistinct to areolate

- Thallus areolate to squamulose 41

37 Apothecial disc black 38

- Apothecial disc brown or orange-yellowish

38 Ascospores 10-14 × 5-7 $\mu \mathrm{m}$

C. festivella

- Ascospores 9-11 × 4-5 $\mu \mathrm{m}$

C. leptozona

39 Prothallus black coloured, thalline margin dark grey

C. aractina

- Prothallus absent, thalline margin persistent

40 Ascospores oblong, 11-13 × 2-4 $\mu \mathrm{m}$

C. leptopisma

- $\quad$ Ascospores ellipsoid to \pm sickle shaped, 5-12 × 1-3 $\mu \mathrm{m}$

C. tropica

41 Medulla yellow

C. lypera

- Medulla white

42 Thallus UV+ yellow C. subleptozona

- $\quad$ Thallus UV-

43 Ascospores longer, 15-18 × 9-11 $\mu \mathrm{m}$

C. diphyodes

- Ascospores small, 10-15 × 6-9 $\mu \mathrm{m}$

44 Thallus growing on sea coast region C. litoricola

- Thallus growing on main inland area 45

45 Disc orange-red or orange-brown 46

- Disc of different colour 
46 Apothecia numerous, disc plane to concave, ascospores 13-17 × 6-8 $\mu \mathrm{m}$, found on temperate to subalpine region

C. ochroplaca

- Apothecia scattered, disc flat to slightly concave, ascospores 10-13 × 5-7 $\mu \mathrm{m}$, found in tropical regions only

C. pellodella

47 Disc brownish black to black

- Disc reddish brown, thallus rimose-areolate to \pm subsquamulose, amphithecium without alga

C. poliotera

48 Prothallus present

- Prothallus absent

C. conciliascens

49 Thallus rimose-areolate, apothecia dark brown to black sessile $\boldsymbol{C}$. orissensis

- Thallus whitish areolate to squamulose, apothecia black immersed to sessile

50 Hypothecium without oil globules, parathecium of elongated hyphal cells, conidia sickle shaped, epihymenium $\mathrm{K}+$ violet

C. transcaspica

- Hypothecium with oil globules, parathecium of isodiametric cells, conidia bacilliform, epihymenium $\mathrm{K}+$ purple

C. pseudisteroides

Caloplaca abuensis Y. Joshi et Upreti, Nova Hedwigia 86(1-2): 261 (2008). - This species is characterised by a rimose-areolate, yellowish orange thallus with whitish globose blisters, which develop into soredia (Joshi 2008). Chemistry: Thallus, apothecial disc and epihymenium $\mathrm{K}+$ purple, $\mathrm{KC}-, \mathrm{C}-$, $\mathrm{Pd}-$ : parietin and olive-green spot at Rf class 4 present in TLC. Ecology and distribution: This species is saxicolous and grows on non-calcareous rocks. It has been found between altitudes of 1,100-2,100 $\mathrm{m}$ in temperate regions of Rajasthan and Uttarakhand.

Representative specimens examined: Rajasthan, Sirohi district, Mt Abu, Honeymoon Point, alt. 1,350 m, on rock, 10.01.1978, S. R. Singh, LWG-LWU-78.138. - Uttarakhand, Champawat district, Gurauli, alt. 1,600 m, on rock, 28.11.2010, G. K. Mishra, LWG10-015234.

Caloplaca aractina (Fr.) Häyrén*, Landveg. Flor. Meeresfels. Tvärminne, p. 152 (1914). - The species is characterised by the crustose, cracked-areolate and often delimited by a black prothallus, upper surface grey to brownish; apothecia $0.4-1.0 \mathrm{~mm}$, sessile, disc dark orange-brown, densely orange pruinose, with a persistent, thick, dark grey thalline margin (Singh 1981). Chemistry: Thallus $\mathrm{K}-, \mathrm{KC}-, \mathrm{C}-, \mathrm{Pd}-$; apothecial disc and epihymenium $\mathrm{K}+$ purple: parietin present in TLC. Ecology and distribution: Saxicolous species reported from Manipur (Singh 1981).

* It is currently shown that this species is a member of the genus Pyrenodesmia. 
Caloplaca atrosanguinea (G. Merr.) I. M. Lamb, Ann. Rep. Nat. Mus. Canada 132: 305 (1954). - The species is characterised by \pm Mischoblastia-type ascospores and $\mathrm{K}+$ strong reddish purple turning blue epihymenium brownish black apothecial disc and pale grey thallus (Joshi 2008). Chemistry: Thallus, soredia and apothecial disc $\mathrm{K}-, \mathrm{C}-$, $\mathrm{Pd}-$; epihymenium and margin $\mathrm{K}+$ strong reddish purple then turning blue: no lichen substance present in TLC. Ecology and distribution: Corticolous species, distributed between elevations of 1,050-1,320 $\mathrm{m}$ in tropical regions of Madhya Pradesh.

Representative specimens examined: Madhya Pradesh, Dindori district, around Karangia forest rest house, alt. 1,320 m, on Pongammia sp. tree trunk, 05.07.2005, D. K. Upreti, S. Nayaka \& Satya, LWG-05-005534; Hoshangabad district, Pachmarhi, on the way to Piparia, alt. 1,050 m, on bark, 28.01.1973, S. R. Singh, LWG-LWU-73.189.

Caloplaca aureosora Poelt et Hinter., Bibl. Lichenol. 50: 81 (1993). - The species is characterised by thin, crustose and granular thallus, with yellow or reddish yellow blastidia, rare apothecia, ascospores 10-15 × 5-10 $\mu \mathrm{m}$, with distinct $4.5 \times 6.5 \mu \mathrm{m}$ wide ascospore septum (Awasthi 1991). Chemistry: Thallus $\mathrm{K}-, \mathrm{KC}-, \mathrm{C}-$, $\mathrm{Pd}-$; apothecial disc and epihymenium $\mathrm{K}+$ purple: parietin present in TLC. Ecology and distribution: Corticolous species, found at an altitude of 2,833 $\mathrm{m}$ in Uttarakhand.

Representative specimen examined: Uttarakhand, Dehra Dun district, Mussoorie/ Chakrata Hills, on the way to Deoban, alt. 2,833 m, on bark, 22.06.1976, D. D. Awasthi \& M. Joshi, LWG-LWU-76.54.

Caloplaca brebissonii (Fée) J. Sant. ex Hafellner et Poelt, J. Hattori Bot. Lab. 46: 18 (1979). - It is characterised by biatorine apothecia with rust brown, plane to convex, epruinose disc, with obtuse to excluded margin, and 25-30 $\times 12-16 \mu \mathrm{m}$ ascospores (Awasthi 1991). Chemistry: Thallus $\mathrm{K}-, \mathrm{KC}-, \mathrm{C}-, \mathrm{Pd}-$; apothecial disc and epihymenium K+ purple: parietin present in TLC. Ecology and distribution: Corticolous species, found only restrictedly in Jammu \& Kashmir (Awasthi 1991).

Representative specimen examined: Jammu \& Kashmir, Udhampur district, Patnitop, Sanasar area, $11 \mathrm{~km}$ away, alt. 2,500 m, on tree trunk, 10.12.2005, M. Sheikh, LWG-05-006681.

Caloplaca cerina (Hedw.) Th. Fr., Nova Acta Regiae Soc. Sci. Upsal., ser. 3, 3: 218 (1861). - The species is characterised by flexuose apothecia with yellow to brownish orange disc, concave when young, surrounded by a distinctive, persistent, grey, smooth to crenulate thalline exciple (Joshi 2008). Chemistry: Thallus $\mathrm{K}-, \mathrm{KC}-, \mathrm{C}-, \mathrm{Pd}-$; apothecial disc and epihymenium $\mathrm{K}+$ purple: parietin present in TLC. Ecology and distribution: Corticolous species growing on walnut and brimji bark with Caloplaca, Candelaria, Lecanora, Phaeophyscia, Physcia and Xanthoria spp., between elevations of 1,500-1,850 m in Jammu \& Kashmir, Manipur, Tamil Nadu and Uttarakhand.

Representative specimens examined: Jammu \& Kashmir, Srinagar district, Harwan, Dachigam National Park, alt. 1,740 m, on trunk of Juglans regia, 03.08.2005, M. Sheikh, 
LWG-05-006693. - Tamil Nadu, Chennai, Elli border, Siruvani Hills, alt. 950 m, on bark, 05.07.1998, G. N. Hariharan \& Balaji, MSSRF-CC16.

Caloplaca cerina var. muscorum (A. Massal.) Jatta, Syll. Lich. Ital., p. 254 (1900). - This variety grows along with moss, apothecia round, 0.4-1.2(-2.0) $\mathrm{mm}$ in diam., flat to convex, orange to orange-brown, proper margin absent, thalline margin thin to moderate, smooth to \pm crenate, disc flush, concolorous with thallus, \pm pruinose (Joshi 2008). Chemistry: Thallus $\mathrm{K}_{-}, \mathrm{KC}-, \mathrm{C}_{-}$, $\mathrm{Pd}-$; apothecial disc and epihymenium K+ purple: parietin present in TLC. Ecology and distribution: Muscicolous species, growing in association with Toninia at an altitude of $1,800 \mathrm{~m}$, restrictedly in Jammu \& Kashmir.

Representative specimen examined: Jammu \& Kashmir, Srinagar district, Shankaracharya Hill, near temple, alt. 1,800 m, on soil, 03.11.1953, D. D. Awasthi, LWG-AWAS-2640A.

Caloplaca cirrochroopsis Poelt et Hinter., Bibl. Lichenol. 50: 108 (1993). This species is characterised by placodioid, orange coloured, closely appressed thallus of radiating lobes $(0.3-1.0 \times 0.2-0.4 \mathrm{~mm})$ with flattened tips, crateriform soralia having yellow-orange granular soredia (Joshi 2008). Chemistry: Thallus and soredia $\mathrm{K}+$ purple, $\mathrm{C}-, \mathrm{KC}-, \mathrm{Pd}-$, I-: parietin and olive spot at Rf 3 present in TLC. Ecology and distribution: The species is mostly saxicolous, growing on non-calcareous rocks between altitudes of 750-2,300 $\mathrm{m}$ in Uttarakhand.

Representative specimens examined: Uttarakhand, Chamoli district, between Bagrigad to Debal, on rock, A. Singh, LWG-90337; Pauri district, Srinagar, Government Inter College, on rock, 18.06.2005, V. Shukla \& Y. Joshi, LWG-05-005251, LWG-05-005254; Pithoragarh district, Gori-Ganga Catchment, East Ghandhura, alt. 1,600-2,000 m, on rock, 03.10.2002, V. Pant, LWG-02-000872; Thali, alt. 2,300 m, on rock, 06.06.2000, V. Pant, LWG-02-67548.

Caloplaca conciliascens (Nyl.) Zahlbr., Cat. Lich. Univ. 7: 109 (1931). The species is characterised by smooth, areolate, ash-grey, $\mathrm{K}+$ yellow thallus, brownish red to brownish black apothecial disc, black thalline margin, parathecium of oval to elongated cells, amphithecium without algae, ascospores 8-12 × 3-6 $\mu \mathrm{m}$, numerous pycnidia and blackish brown to black ostiole (Joshi 2008). Chemistry: Thallus $\mathrm{K}+$ yellow, $\mathrm{C}-, \mathrm{Pd}-, \mathrm{cN}+$ violet; apothecial disc $\mathrm{K}-$ and epihymenium K+ violet: atranorin present in TLC. Ecology and distribution: Saxicolous species growing on non-calcareous rocks along with Peltula and Endocarpon spp. in tropical regions at an altitude of $500 \mathrm{~m}$ in Uttar Pradesh.

Representative specimen examined: Uttar Pradesh, Mirzapur district, Kotwa, Wyndhom falls, $14 \mathrm{~km}$ from Mirzapur city, alt. ca $500 \mathrm{~m}$, on rocks, 05.02.1980, D. K. Upreti \& U. C. Misra, LWG-80-647.

Caloplaca crocea (Kremp.) Hafellner et Poelt, J. Hattori Bot. Lab. 46: 19 (1979). - The species is characterised by a continuous to subareolate, smooth, thin, membranous, whitish grey, UV+ cream-yellow, K- thallus, yellow to yellowish orange apothecial disc, persistent thalline margin, parathecium of radiating elongated hyphal cells, amphithecium with algae, outer surface with hyaline crystals and trilocular ascospores with middle locule of similar size 
as polar locules (Joshi 2008). Chemistry: Thallus UV+ orange; apothecial disc and epihymenium $\mathrm{K}+$ purple, $\mathrm{KC}-, \mathrm{C}-, \mathrm{Pd}-$ : parietin present in TLC. Ecology and distribution: Corticolous species with narrow distribution in Tamil Nadu at an altitude of $1,100 \mathrm{~m}$.

Representative specimen examined: Tamil Nadu, Chennai district, Pulmedu, Siruvani Hills, alt. 1,100 m, on bark, 18.11.1996, G. N. Hariharan \& Balaji, MSSRF-CC9.

Caloplaca cupulifera (Vain.) Zahlbr., Cat. Lich. Univ. 7: 226 (1931). - It is readily distinguished by a yellowish orange areolate thallus, with slightly lobed marginal areoles, laminal, crateriform eroding soralia having yellowish soredia (Joshi 2008). Chemistry: Thallus K+ purple, KC-, C-, Pd-: parietin present in TLC. Ecology and distribution: A most widely distributed saxicolous species in India growing on both calcareous and non-calcareous rocks in moist and dry habitats of tropical to temperate regions in Andhra Pradesh, Bihar, Jharkhand, Himachal Pradesh, Madhya Pradesh, Orissa, Rajasthan, Tamil Nadu, Uttarakhand, Uttar Pradesh and West Bengal.

Representative specimens examined: Andhra Pradesh, Vishakhapatnam, near Tyada, 70 km from Vishakhapatnam, 08.03.1986, D. D. Awasthi, G. Awasthi, R. Mathur \& P. Srivastava, LWG-LWU-86.277. - Bihar, Singh Bhoom (East) district, around Jaduguda Uranium Mines, on rock, 16.08.1997, S. Chatterjee, LWG-L69782. - Himachal Pradesh, Kullu district, Parbati river valley, Bhandag, 3 miles up from Pulga, alt. 3,150 m, on rocks, 21.06.1975, D. D. Awasthi \& K. Dange, LWG-LWU-75.245. - Madhya Pradesh, Katni district, Bahoriband, on exposed siliceous rock, 22.02.2009, G. K. Mishra \& S. Mohabe, LWG-09-010601, LWG-09010604; Rewa district, Govindgarh, Chhuiyaghati, on exposed siliceous rock, 18.02.2009, G. K. Mishra \& S. Mohabe, LWG-09-010652/A; Satna district, Maihar, near Sardadevi temple, $46 \mathrm{~km}$ from Satna, on rock, 04.12.2009, S. Mohabe \& G. K. Mishra, LWG-09-012838/A; Panna district, Badorshiha near diamond mine, on exposed rock, 06.12.2009, S. Mohabe \& G. K. Mishra, LWG-09-012889/A; Sidhi district, Bargawan, on siliceous rock, 15.09.2010, S. Mohabe \& G. K. Mishra, LWG-10-013352. - Orissa, Puri district, Khandgiri, near Bhubaneshwar, on rock, 27.02.1986, D. D. Awasthi, G. Awasthi, R. Mathur \& P. Srivastava, LWGLWU-86.017. - Rajasthan, Sirohi district, Mt Abu, Honeymoon Point, 10.01.1978, S. R. Singh, LWG-LWU-78.105. - Tamil Nadu, Kalkotti, Siruvani Hills, alt. 450 m, on rocks, 26.06.1997, G. N. Hariharan, MSSRF-CS1. - Uttar Pradesh, Mahoba district, Mahoba, Bukhra Pahar, on exposed sandstone, 05.12.2000, D. K. Upreti, Z. H. Khan \& S. Dwivedi, LWG-20-104877, LWG-20-104878. - Uttarakhand, Bageshwar district, Pindari Glacier; Loharkhet, on rock, 09.05.2007, Y. Joshi \& S. Joshi, LWG-07-010100; Pithoragarh district, Munsiyari to Lilam, Milam glacier, alt. 1,800-2,250 m, on rock, 16.10.2007, S. Joshi, LWG-07-010547.

Caloplaca diphyodes (Nyl.) Jatta*, Syll. Lich. Ital., p. 259 (1900). - This species is distinguished by rimulose to effuse thallus, dark brown apothecia with entire margin, ovoid ascospores, 15-18 × 9-11 $\mu \mathrm{m}$ (Awasthi 1991). Chemistry: Thallus $\mathrm{K}+$ purple, $\mathrm{KC}-, \mathrm{C}-, \mathrm{Pd}-$ : parietin present in TLC. Ecology and distribution: It grows on rock at an altitude of 2,700 $\mathrm{m}$ and has a restricted distribution in Jammu \& Kashmir (Awasthi 1991). Taxonomic note:

* It is currently shown that this species is a member of the genus Pyrenodesmia. 
This is a member of the Pyrenodesmia branch of the phylogenetic tree of the Teloschistaceae.

Caloplaca encephalarti (Kremp.) Zahlbr., Cat. Lich. Univ. 7: 115 (1930) [1931]. - This species is distinct by the biatorine apothecia, yellow-brown to pale reddish apothecial disc, excluded margin and 8-12 $\times 4.5-6.5 \mu \mathrm{m}$ ascospores (Awasthi 1991). Chemistry: Thallus K+ purple, KC-, C-, Pd-: parietin present in TLC. Ecology and distribution: Corticolous species from West Bengal (Awasthi 1991).

Caloplaca festivella (Nyl.) Kieff., Bull. Soc. Hist. Nat. Metz 19: 66 (1895). - This species is characterised by the dark grey to bluish grey thallus, black prothallus, partly ferrugineus to blackish apothecia, with irregularly black margin, 10-14 × 5-7 $\mu \mathrm{m}$ ascospores. The description and distribution of this species is based on published literature (Awasthi 1991). Chemistry: Thallus K+ purple, $\mathrm{KC}-, \mathrm{C}-$, $\mathrm{Pd}-$ : parietin present in TLC. Ecology and distribution: The species grows on rocks between altitudes of 500-840 m in Madhya Pradesh. Taxonomic notes: This is a member of the Blastenia branch of the phylogenetic tree of the Teloschistaceae. Current name of this species is Blastenia festivella (Nyl.) Vondrák, which was proposed by Vondrák et al. (2019).

Caloplaca fraudans (Th. Fr.) H. Olivier, Mém. Soc. natn. Sci. nat. Cherbourg 37: 138 (1909). - The species is characterised by pale yellowish thallus (when developed), numerous orange-brown apothecia with inflexed pale margin, oil globules in hypothecium and the narrow ascospores with thin septum (Joshi 2008). Chemistry: Thallus, apothecial disc and epihymenium $\mathrm{K}+$ purple, $\mathrm{C}-$, $\mathrm{Pd}-$ : parietin present in TLC. Ecology and distribution: Saxicolous species growing on siliceous rocks along with Acarospora, Aspicilia, Buellia and Lecanora spp. between elevations of 2,500-3,100 m in Himachal Pradesh and Uttarakhand.

Representative specimens examined: Himachal Pradesh, Kangra district, Mauali, E side of river, on rock, 08.07.1952, O. A. Höeg, LWG-LWU-1521. - Uttarakhand, Uttarkashi district, Gangotri, towards Kedartal, alt. 3,100 m, on rock, 08.09.2002, S. Chatterjee \& P. K. Divakar, LWG-02-000407.

Caloplaca fulvolutea (Arnold) Jatta, Syll. Lich. Ital., p. 245 (1900). - This species is characterised by the white, granular to subgranular thallus and biatorine apothecia, ochraceous orange apothecial disc, $14-21 \times 7-11 \mu \mathrm{m}$ ascospores (Awasthi 1991). Chemistry: Thallus K+ purple, KC-, C-, Pd-: parietin present in TLC. Ecology and distribution: Reported from soil between altitudes of 950-2,150 m in Himachal Pradesh (Awasthi 1991).

Caloplaca gyrophorica Jagad. Ram, Y. Joshi et G. P. Sinha, Mycotaxon 122: 304 (2012). - It is characterised by an areolate to subsquamulose greyish brown thallus, brownish orange, lecanorine apothecia with concolorous mar- 
gins, and gyrophoric acid and parietin as major chemical constituents (Joshi et al. 2012). Chemistry: Thallus $\mathrm{K}-, \mathrm{C}+\mathrm{red}, \mathrm{KC}+\mathrm{red}, \mathrm{Pd}-$; epihymenium $\mathrm{K}+\mathrm{red}$, $\mathrm{KC}-, \mathrm{C}-, \mathrm{Pd}-$ : gyrophoric acid and parietin present in TLC. Ecology and distribution: Saxicolous species growing on exposed siliceous rocks at altitudes of $c a 2,400 \mathrm{~m}$ in few localities of West Bengal. Taxonomic notes: This species probably belongs to the genus Upretia. However, this hypothesis should be checked with molecular data.

Representative specimen examined: West Bengal, Darjeeling district, Kalimpong subdivison, Neora Valley National Park, Aloobari, $27^{\circ} 07^{\prime} 33.1^{\prime \prime}$ N, $88^{\circ} 42^{\prime} 55.2^{\prime \prime}$ E, alt. 2,479 m, on exposed siliceous rocks, 17.05.2008, T. A. M. Jagadeesh Ram, BSA-4356 (holotype).

Caloplaca haematites (Chaub.) Zwackh, Flora 45: 487 (1862)*. - This species is characterised by verruculose, orbicular thallus, grey to bluish prothallus, plane to convex, bright red apothecial disc, whitish grey, tumid, persistent margin, ovoid-elliptical, slightly curved, ascospores of 6-9 $\times 5 \mu \mathrm{m}$ (Awasthi 1991). Chemistry: Thallus K+ purple, KC-, C-, Pd-: parietin present in TLC. Ecology and distribution: Corticolous species growing between altitudes of 1,000-2,150 m in Jammu \& Kashmir (Awasthi 1991).

Caloplaca handelii (Zahlbr.) D. D. Awasthi, Bibl. Lichenol. 40: 2 (1991). The species is characterised by biatorine apothecia, carneous brown disc, $\mathrm{K}+$ violet epithecium, 9-15 × 6-8 $\mu \mathrm{m}$ ascospores (Singh 1981, Awasthi 1991). Chemistry: Thallus K+ purple, KC-, C-, Pd-: parietin present in TLC. Ecology and distribution: Saxicolous species reported from Manipur (Singh 1981, Awasthi 1991).

Caloplaca heterospora Poelt et Hinter., Bibl. Lichenol. 50: 138 (1993). The species is characterised by yellow-orange squamulose thallus dissolved in concolorous soredia/blastidia, orange-brown apothecial disc less than or equal to 8 ascospores, which are very much variable in shape (Joshi 2008). Chemistry: Thallus, apothecial disc and epihymenium $\mathrm{K}+$ purple, $\mathrm{KC}-, \mathrm{C}_{-}$, $\mathrm{Pd}-$ : parietin present in TLC. Ecology and distribution: It grows on calcareous soil in Himachal Pradesh.

Representative specimen examined: Himachal Pradesh, Kangra district, Chandra valley, at Chatory, on soil, 18.07.1952, O. A. Höeg, LWG-AWAS-1543.

Caloplaca himalayana Y. Joshi et Upreti, Lichenologist 41(3): 250 (2009). - The species is characterised by yellowish thallus having ferrugineus apothecial disc (Joshi 2008). Chemistry: Thallus, apothecial disc and epihymenium $\mathrm{K}+$ purple, $\mathrm{KC}-, \mathrm{C}-\mathrm{-}, \mathrm{Pd}-$. Dull yellow-beige colour at Rf 7 and yellow spot between Rf 5 and 6 present in TLC. Ecology and distribution: It grows over dead wood between the altitude of 2,150-2,800 $\mathrm{m}$ in temperate regions of Himachal Pradesh and Jammu \& Kashmir.

* It is currently shown that this species is a member of the genus Pyrenodesmia. 
Representative specimens examined: Himachal Pradesh, Shimla district, Narkanda, 3-4 km towards Hatu Peak, alt. 2,800 m, on dead wood, 14.05.2002, S. Nayaka \& R. Srivastava, LWG-02-81522. - Jammu \& Kashmir, Udhampur district, Patnitop, Tourist area, alt. 2,150 m, on dead wood, 09.12.2005, M. Sheikh, LWG-05-034675. - Uttarakhand, Champawat district, Vanlekh on the way to Champawat, alt. 1,600 m, on bark, 29.11.2010, G. K. Mishra, LWG-010-015645; Near Guest House Champawat, alt. 1,600 m, on bark, 26.11.2010, G. K. Mishra, LWG-10-015226; Nainital district, Bhotia field (near Budda Temple), alt. 2,100 m on bark, 11.12.2009, H. Kholia, LWG-09-014894.

Caloplaca homologa (Nyl.) Hellb., Bih. Kongl. Svenska Vetensk. Akad. Handl. Afd. 3 21(13): 68 (1896). - The species is characterised by white, rugulose thallus, lecanorine apothecia, entire margin, articulate paraphyses, and 22-25 × 11-12 $\mu \mathrm{m}$ ascospores (Awasthi 1991). Chemistry: Thallus K+ purple, $\mathrm{KC}-, \mathrm{C}-, \mathrm{Pd}-$ : parietin present in TLC. Ecology and distribution: Corticolous species with restricted distribution in Uttarakhand (Awasthi 1991).

Caloplaca indica Y. Joshi, Jagad. Ram et G. P. Sinha, Nat. Acad. Sci. Letters 37(6): 517 (2014). - The species is characterised by greyish, UV+ orange thallus, biatorine to lecanorine apothecia, bi- to trilocular ascospores, and an amphithecium with pale brown crystals confined in the upper region (Joshi et al. 2014). Chemistry: Thallus $\mathrm{K}-, \mathrm{C}-, \mathrm{Pd}-$, UV+ yellow-orange; apothecial disc $\mathrm{K}-, \mathrm{C}-$, $\mathrm{Pd}-$ : parietin traces present in TLC. Ecology and distribution: Corticolous species reported from montane rainforests between altitudes of 2,306-2,344 $\mathrm{m}$ in Arunachal Pradesh and West Bengal. According to Joshi et al. (2014) the species is associated with Arthopyrenia majuscula, Bacidia rubella, Cryptothecia stirtonii, Lecanora albella, Heterodermia diademata and Parmotrema thomsonii.

Representative specimen examined: Arunachal Pradesh, West Kameng district, 15 $\mathrm{km}$ to Sange, Doran Sange road, alt. 2,306-2,344 m, on bark, 05.03.2009, K. P. Singh \& G. Swarnalatha, BSA-4979.

Caloplaca insularis Poelt, Planta 51: 300 (1958). - The species is characterised by indistinct thallus, sessile to \pm stipitate apothecia, thick, orangeochraceous margin, plane apothecial disc, darker than the thallus, 11-14 $\times$ 5.5-8 $\mu \mathrm{m}$ ascospores (Awasthi 1991). Chemistry: Thallus K+ purple, KC-, C-, $\mathrm{Pd}-$ : parietin present in TLC. Ecology and distribution: Saxicolous species growing between altitudes of 755-1,650 $\mathrm{m}$ of temperate regions in Jammu \& Kashmir and Uttarakhand, parasitic on Aspicilia spp. (Awasthi 1991).

Caloplaca irrubescens (Arnold) Zahlbr., Verh. zool.-bot. Ges. Wien 48: 365 (1898). - Thallus distinctly squamulose, adnate to mostly somewhat desisting, squamules yellow to reddish orange, up to $1 \mathrm{~mm}$ in diam., parathecium paraplectenchymatous, i.e. composed of roundish or angular cells, ascospores 10.5-15(-16) × 6-8 $\mu \mathrm{m}$, septum 2.5-4 $\mu \mathrm{m}$ wide (Joshi 2008). Chemistry: Thallus $\mathrm{K}+$ purple, $\mathrm{KC}-, \mathrm{C}-\mathrm{Pd}-\mathrm{P}$ : parietin present in TLC. Ecology and distribution: It grows on extremely acidic siliceous rocks, temperate to warm temperate zones 
of Himachal Pradesh and Uttarakhand. Taxonomic notes: Poelt and Hinteregger (1993) reporting this species from India mentioned that the conspecificity of the Himalayan and the European materials was not certain. This is a member of the Squamulea branch of the phylogenetic tree of the Teloschistaceae.

Representative specimens examined: Himachal Pradesh, Bilaspur district, Paniyala, alt. 500 m, on rock, 05.04.2003, D. K. Upreti, LWG-03-001920. - Madhya Pradesh, Anoopur district, Amarkantak, $3 \mathrm{~km}$ from Jwaleshwar, alt. $603 \mathrm{~m}$, on rock, 23.03.2004, D. K. Upreti, S. Nayaka \& Satya, LWG-04-002840, LWG-04-002851, LWG-04-002869. - Tamil Nadu, Palni Hills, Oothu area, alt. 1,050-1,200 m, 04.01.1970, D. D. Awasthi \& K. P. Singh, LWGLWU-70.361. - Uttarakhand, Almora district, Almora, Thapalia village, G. B. Tewari house, alt. 1,500 m, on rock, 03.05.1988, D. K. Upreti, LWG-L18397.

Caloplaca jatolensis Y. Joshi et Upreti, Lichenologist 40(6): 535 (2008). This species is mainly characterised by a grey, membranous thallus, lecanorine apothecia, trilocular ascospores with a constriction in their centre, and an amphithecium with anthraquinone and hyaline crystals in the outer surface (Joshi 2008). Chemistry: Thallus $\mathrm{K}+$ pale yellow, $\mathrm{KC}-, \mathrm{C}-$, $\mathrm{Pd}-$, UV+ creamyellow; apothecial disc $\mathrm{K}-, \mathrm{C}-, \mathrm{Pd}-$. Atranorin, grey spot at Rf 3 and $\mathrm{UV}+$ ice blue spot at Rf 7 present in TLC. Ecology and distribution: Corticolous species growing on Quercus semecarpifolia bark between altitudes of 2,700-3,300 m along with Lecanora sp. in subalpine regions of Uttarakhand.

Representative specimen examined: Uttarakhand, Bageshwar district, en route to Sunderdunga Glacier, between Jatoli \& Dhuniyadon, alt. 2,700-3,000 m, on bark of Quercus, 14.05.1995, D. K. Upreti \& J. Tandon, LWG-213500 (holotype).

Caloplaca kashmirensis Y. Joshi et Upreti, Nova Hedwigia 86(1-2): 267 (2008). - This species is characterised by orange coralloid isidia, lecanorine apothecia and an inspersed hypothecium (Joshi 2008). Chemistry: Thallus, isidia, apothecial disc and epihymenium $\mathrm{K}+$ purple, $\mathrm{KC}-, \mathrm{C}-, \mathrm{Pd}-$ : parietin present in TLC. Ecology and distribution: Corticolous species growing on mango bark at an elevation of $605 \mathrm{~m}$ in moist places of Jammu \& Kashmir. Taxonomic notes: This species probably belongs to the genus Laundonia. However, this hypothesis should be checked with molecular data.

Representative specimens examined: Assam, Dima Hasao district, Dihangi, Thesiling Hower, near bus stops, 52 km from New Haflong, alt. 273 m, on bark, 01.04.2017, G. K. Mishra, LWG-17-029684; In and around circuit house, New Haflong, alt. 703 m, on bark, 02.04.2017, G. K. Mishra, LWG-17-029666. - Jammu \& Kashmir, Jammu district, Surinsar, bank of Surinsar Lake, alt. $605 \mathrm{~m}$, on bark of Mangifera indica, 04.06.2005, M. A. Sheikh \& A. K. Raina, LWG-05-006607 (holotype).

Caloplaca leptopisma (Nyl.) Zahlbr., Cat. Lich. Univ. 7: 242 (1930). - This species is distinguished by the depressed, diffract-rimose, sublobulate thallus, and oblong ascospores, 11-13 4 4m (Awasthi 1991). Chemistry: Thallus $\mathrm{K}+$ purple, $\mathrm{KC}-, \mathrm{C}-$, $\mathrm{Pd}-$ : parietin present in TLC. Ecology and distribution: Saxicolous species from the NW Himalaya region (Awasthi 1991). 
Caloplaca leptozona (Nyl.) Zahlbr., Cat. Lich. Univ. 7: 154 (1930). - This species is distinguished by the rimose-areolate, squamulose thallus, plane, flat, brownish to reddish brown, epruinose apothecial disc, and 4-11 $\times 5.5 \mu \mathrm{m}$ ascospores (Balaji and Hariharan 2005). Chemistry: Thallus K+ purple, KC-, C-, Pd-: parietin present in TLC. Ecology and distribution: The species occurs on rocks in inland areas between altitudes of 1,000-1,800 $\mathrm{m}$ in subtropical to temperate regions of Tamil Nadu (Balaji and Hariharan 2005).

Caloplaca lithophila H. Magn., Ark. Bot. 33A(1): 132 (1946). - The species is characterised by small, yellow to orange, convex apothecia with thin margins, inconspicuous yellow thallus, broad ascospores with wide septa and oil globules in top cells of the paraphyses (Joshi 2008). Chemistry: Thallus K-, $\mathrm{KC}-, \mathrm{C}-$, I-; apothecial disc and epihymenium $\mathrm{K}+$ purple, margin $\mathrm{K}-$ (remaining aeruginose): parietin present in TLC. Ecology and distribution: Saxicolous species growing along with species of Aspicilia, Caloplaca, Porpidia, Rusavskia, Staurothele and Verrucaria in temperate to subalpine regions of Uttarakhand.

Representative specimen examined: Uttarakhand, Uttarkashi district, Govind Wildlife Sanctuary, en route to Devkyara, near bridge of Supin and Obra Ghat, alt. 2,065 m, on rock, 18.10.2016, S. Nayaka, LWG-16-030801.

Caloplaca litoricola Brodo, Bryologist 87(2): 98 (1984). - The species is characterised by whitish grey, continuous or areolate thallus, black proper margin and orange-yellow to dark orange apothecial discs, parathecium of radiating elongated hyphal cells, ascospores oval to ellipsoid, 11-16 × 6-9 $\mu \mathrm{m}$ and isthmus 5-6 $\mu \mathrm{m}$, ostiole black and is strictly a littoral species (Joshi 2008). Chemistry: Thallus $\mathrm{K}-, \mathrm{KC}-, \mathrm{C}-$, I-; apothecial disc and epihymenium $\mathrm{K}+$ purple, margin $\mathrm{K}-$ (remaining aeruginose): parietin present in TLC. Ecology and distribution: It grows on siliceous rocks in tropical regions of Andhra Pradesh.

Representative specimen examined: Andhra Pradesh, Vishakhapatnam, along sea coast, on rock, 07.03.1986, D. D. Awasthi, G. Awasthi, R. Mathur \& P. Srivastava, LWGLWU-86.272.

Caloplaca lypera Poelt et Hinter., Bibl. Lichenol. 50: 159 (1993). - It is mainly characterised by irregularly cracked areolate, greyish or ochraceous coloured thallus, yellow medulla and reddish brown to olivaceous black apothecial disc surrounded by a yellowish thalline margin (Joshi 2008). Chemistry: Thallus $\mathrm{K}-$ to $\mathrm{K}+$ faint purple in some regions, $\mathrm{KC}-, \mathrm{C}-$, $\mathrm{Pd}-$; apothecial disc and epihymenium $\mathrm{K}+$ purple, $\mathrm{C}-$, $\mathrm{Pd}-$-: parietin present in TLC. Ecology and distribution: Saxicolous species growing between altitudes of 2,200-2,700 $\mathrm{m}$ in temperate regions of Uttarakhand.

Representative specimens examined: Uttarakhand, Pithoragarh district, Munsiyari, alt. 2,200 m, on rock, 17.11.2006, Y. Joshi \& R. Bajpai, LWG-06-007008, LWG-06-006276, LWG-06-006273. 
Caloplaca malaeensis (Räsänen) D. D. Awasthi, Beih. Nova Hedwigia 17: 34 (1965). - This species is characterised by its smooth thallus when it is young, membranaceous, bright yellow, soon developing isidia-like, more or less branched blastidia, orange-brownish apothecia, their excipular margins finally also blastidiate. Chemistry: Thallus $\mathrm{K}_{-}, \mathrm{KC}-, \mathrm{C}_{-}$, I-; apothecial disc and epihymenium $\mathrm{K}+$ purple, margin $\mathrm{K}-$ (remaining aeruginose): parietin present in TLC. Ecology and distribution: Corticolous species growing in tropical to subtropical zone of Uttarakhand and Karnataka. Taxonomic notes: It is possibly a member of the genus Oxneriopsis, but molecular data for this species are still not available.

Representative specimen examined: Uttar Pradesh, Pilibhit district, Mala forest, alt. $800 \mathrm{ft}$, on bark, 14.12.1949, D. D. Awasthi, LWG-AWAS-540.

Caloplaca maura Poelt et Hinter., Bibl. Lichenol. 50: 161 (1993). - The species is characterised by indistinct to squamulose grey thallus, brownish to brownish black to black apothecial disc, which is \pm covered by yellowish granules (Joshi 2008). Chemistry: Thallus $\mathrm{K}-, \mathrm{KC}-, \mathrm{C}_{-}, \mathrm{Pd}-$; apothecial disc and epihymenium $\mathrm{K}+$ purple, $\mathrm{C}-, \mathrm{Pd}-$ : parietin present in TLC. Ecology and distribution: It grows in alpine region of Sikkim at higher altitude of 4,600 m.

Representative specimen examined: Sikkim, North Sikkim, Giagaon, above Thanngu, alt. 4,600 m, on detritus, 13.08.2004, D. K. Upreti, S. Chatterjee \& P. K. Divakar, LWG04-004004.

Caloplaca ochroplaca Poelt et Hinter., Bibl. Lichenol. 50: 165 (1993). - The species is characterised by an ochraceous grey areolate thallus with sunken orange apothecia (Joshi 2008). Chemistry: Thallus $\mathrm{K}-, \mathrm{KC}-, \mathrm{C}-$, Pd-; apothecial disc and epihymenium K+ purple: parietin present in TLC. Ecology and distribution: Saxicolous species growing on siliceous rocks in association with Acarospora and other Caloplaca species between altitudes of 1,980-2,800 m in temperate regions of Himachal Pradesh, Jammu \& Kashmir and Uttarakhand.

Representative specimens examined: Himachal Pradesh, Kullu district, Great Himalayan National Park, around Shilt, alt. 3,000 m, on exposed rocks in grasslands, 06.09.1999, D. K. Upreti, LWG-99-53621. - Jammu \& Kashmir, Anantnag district, Pahalgam, E side, alt. 2,450 m, on rock, 31.07.2005, M. Sheikh, LWG-05-034678. - Uttarakhand, Bageshwar district, on the way to Khati from Dhakuri, alt. 2,210 m, on rock, 12.05.2007, Y. Joshi \& S. Joshi, LWG-07-010091, LWG-07-010096.

Caloplaca orissensis (Räsänen) D. D. Awasthi, Bibl. Lichenol. 40: 2 (1991). - This species is characterised by the presence of rimose-areolate thallus that becomes yellow on application of $\mathrm{K}$ and having black apothecia (Joshi 2008). Chemistry: Thallus $\mathrm{K}+$ yellow, $\mathrm{KC}-, \mathrm{C}-$, Pd-; apothecial disc $\mathrm{K}-$, but epihymenium K+ purple: parietin and atranorin present in TLC. Ecology and distribution: Saxicolous species growing on both calcareous and non-calcareous rocks in Orissa.

Representative specimen examined: Orissa, Cheriakuda Islands, near Borkuda, in Chilka Lake, at sea level, on stone, 03.1948, D. D. Awasthi, LWG-AWAS-352. 
Caloplaca pachycheila Poelt et Hinter., Bibl. Lichenol. 50: 168 (1993). The species is characterised by indistinct yellow thallus, numerous orangebrown small apothecia, hypothecium with or without oil globules and anastomosed paraphyses (Joshi 2008). Chemistry: Thallus, apothecial disc and epihymenium $\mathrm{K}+$ purple, $\mathrm{KC}-, \mathrm{C}-, \mathrm{Pd}-$ : parietin present in TLC. Ecology and distribution: Saxicolous species growing on calcareous and non-calcareous rocks between altitudes of 1,500-3,600 $\mathrm{m}$ in temperate and alpine regions of Jammu \& Kashmir and Uttarakhand in association with Acarospora fusca and Lecanora campestris.

Representative specimens examined: Jammu \& Kashmir, Pulwama district, Pinalgam, in residential area, alt. 1,584 m, on bricks of roof, 04.07.2004, M. Sheikh, LWG-04004837, LWG-04-004839. - Uttarakhand, Bageshwar district, Phurkia-Pindari, alt. 3,450 m, on stones, 23.05.1950, D. D. Awasthi \& A. M. Awasthi, LWG-AWAS-783.

Caloplaca pellodella (Nyl.) Hasse, Contr. US Natl. Herb. 17: 115 (1913). - This species is distinguished by the olivaceous green, squamulose thallus, apothecial disc concolorous with thallus, $\mathrm{K}+$ purple epithecium, and $10-11 \times$ 5-6 $\mu \mathrm{m}$ ascospores (Awasthi 1991). Chemistry: Thallus $\mathrm{K}+$ purple, $\mathrm{KC}-, \mathrm{C}-$, $\mathrm{Pd}-$ : parietin present in TLC. Ecology and distribution: Saxicolous species growing at an altitude of $700 \mathrm{~m}$ having restricted distribution in Tamil Nadu (Awasthi 1991).

Caloplaca phloginopsis Poelt et Hinter., Bibl. Lichenol. 50: 174 (1993). The species is mainly characterised by a thin, membranous, indistinct, pale yellow thallus with pale yellowish white soredia of medullary origin (Joshi 2008). Chemistry: Thallus and soredia $\mathrm{K}+$ purple, $\mathrm{KC}-, \mathrm{C}-, \mathrm{Pd}-$ : parietin present in TLC. Ecology and distribution: Corticolous species growing on Cedrus, Euphorbia and Quercus bark between altitudes of 1,300-3,400 m in Himachal Pradesh.

Representative specimen examined: Himachal Pradesh, Kullu district, Great Himalayan National Park, ecodevelopmental zone, Sainj Valley, Lopah, alt. 2,240 m, on Cedrus deodara bark, 11.06.2004, S. Nayaka \& R. Srivastava, LWG-04-003417.

Caloplaca poliotera (Nyl.) Steiner, Sitzungsber. Akad. Wiss. Wien, Math.-naturw. Kl., 106: 219 (1897). - This species is characterised by rimoseareolate thallus, which gives $\mathrm{K}+$ yellow reaction and dark brown apothecial disc with black margin (Joshi 2008). Chemistry: Thallus K+ yellow, KC-, C-, $\mathrm{Pd}-$; apothecial disc and epihymenium $\mathrm{K}+$ purple: parietin and atranorin present in TLC. Ecology and distribution: Saxicolous species growing on both calcareous and non-calcareous rocks in Tamil Nadu.

Representative specimens examined: Madhya Pradesh, Katni district, Bahoriband, on exposed siliceous rock, 22.02.2009, G. K. Mishra \& S. Mohabe, LWG-09-010627/C; Rewa district, Bahuti, Mauganj, on exposed siliceous rock, 17.02.2009, G. K. Mishra \& S. Mohabe, LWG-09-009163/A; Satana district, Satianusuiya pahadi, Chitrakoot, on exposed rock, 05.12.2009, S. Mohabe \& G. K. Mishra, LWG-09-012840/C. - Tamil Nadu, Chennai, Velliangiri, Siruvani Hills, alt. 600 m, on rock, 23.10.1999, G. N. Hariharan \& Balaji, MSSRF-CS9. 
Caloplaca pseudisteroides Y. Joshi et Upreti, Lichenologist 40(6): 537 (2008). - It is characterised by a vivid grey to greyish brown to vivid yellow, areolate to subsquamulose thallus, pale brown to brownish black apothecial disc and firmly conglutinated paraphyses (Joshi 2008). Chemistry: Thallus K- to K+ faint purple at yellowish regions, $\mathrm{KC}-, \mathrm{C}-, \mathrm{Pd}-, \mathrm{UV}-$; apothecial disc $\mathrm{K}+$ purple, $\mathrm{C}-$, $\mathrm{Pd}-$ : parietin in yellowish regions of thallus and apothecial disc, atranorin in thallus present in TLC. Ecology and distribution: Saxicolous species growing along with Squamulea subsoluta and Upretia amarkantakana and association with other lichen species (Endocarpon, Staurothele and Verrucaria) in Madhya Pradesh.

Representative specimens examined: Bihar, Singh Bhoom (East) district, around Jaduguda Uranium Mines, 16.08.1997, S. Chatterjee, LWG-L69774. - Madhya Pradesh, Katani district, Bahoriband, on exposed siliceous rock, 22.02.2009, G. K. Mishra \& S. Mohabe, LWG-09-010618/A. Panna district, Badorshiha near diamond mine, on exposed rock, 06.12.2009, S. Mohabe \& G. K. Mishra, LWG-09-012880, LWG-09-012856, LWG-09012856/A; Rewa district, Bahuti, Mauganj, $35 \mathrm{~km}$ away from Rewa, on siliceous exposed rock, 17.02.2009, G. K. Mishra \& S. Mohabe, LWG-09-009165. - Orissa, Ganjam district, on the way to Seranga, 03.03.1986, D. D. Awasthi, G. Awasthi, R. Mathur \& P. Srivastava, LWG-LWU-86.148. - Tamil Nadu, Chennai, Vellianangiri base, Siruvani Hills, alt. 610 m, on rocks, 01.10.1999, G. N. Hariharan \& P. Balaji, MSSRF-CS11a. - Uttar Pradesh, Mahoba district, Bukhra Pahar, on sandstone rocks in moist places, 05.12.2000, D. K. Upreti, Z. H. Khan \& S. Dwivedi, LWG-20-104886.

\section{Caloplaca rajasthanica S. Y. Kondr., Upreti et G. P. Sinha, spec. nova} (Figs 1, 5)

MycoBank No.: MB 832434

Similar to Caloplaca zeravshanica, but differs in having mainly regularly rounded or rosette-like thalli entirely developed in the centre, in having mainly areolate thallus with distinct peripheral zone, in having thalline areoles distinctly thinning towards the tips, and much thicker in the centre of thallus, as well as in having mainly an evenly coloured dull brownish yellow thallus.

Type: India, Rajasthan, Mt Abu, W. L. Forest, Honeymoon Point, lat.: 243 36' 00.1" N, long.: $72^{\circ} 41^{\prime}$ 51.6" E, alt.: 1,142 $\pm 10 \mathrm{~m}$, on rock, 06.09.2012, G. P. Sinha \& R. Kar, BSA-7806 (holotype).

Thallus to (1.5-)2-3(-4) cm across, rosette-like or regularly rounded, mostly compact, film-like, where areoles, lobes more or less closely attached to each other (not distant), with well-developed areolate to lobate peripheral zone to 1.5-2.5(-3.5) mm wide; areoles of peripheral zone 1-1.5(-2) mm across, with very narrow whitish tips, and upper surface dull brownish yellow, matt, without pruina, lobes of peripheral portion [if developed] to (1-)2-2.5(-3.5) $\mathrm{mm}$ long, more or less widened towards the tips to $1-1.5 \mathrm{~mm}$ wide, and with 
characteristic lateral incisions, dissections (similarly to Caloplaca anularis or C. zeravshanica, see below), distinctly becoming thinner towards the tips (and seem to be closely attached to the substrate in peripheral zone while more lax or convex in the centre), rarely peripheral portion not developed. The centre of the thallus is compact to entire film-like or areolate, very thick, thalline areoles to (0.3-)0.8-1.5(-2) mm across and to $0.5-1(-2) \mathrm{mm}$ thick, becoming somewhat wider and distinctly thickened in comparison with peripheral portions, very irregular, often densely packed and overlapping, forming much larger, somewhat irregular, convex 'pseudoareoles' to 1.5-2.5(-3) mm across (i.e. central portion verruculose or papillose to somewhat 'Toninia-like'), or upper surface more or less entire; often with damaged portion where some areoles disappeared and naked white medulla well seen and well contrasting to upper surface of thallus; ${ }^{*, * *}$ upper surface smooth and matt or somewhat slightly shiny, dull yellow brownish. Vegetative propagules (isidia or sore-
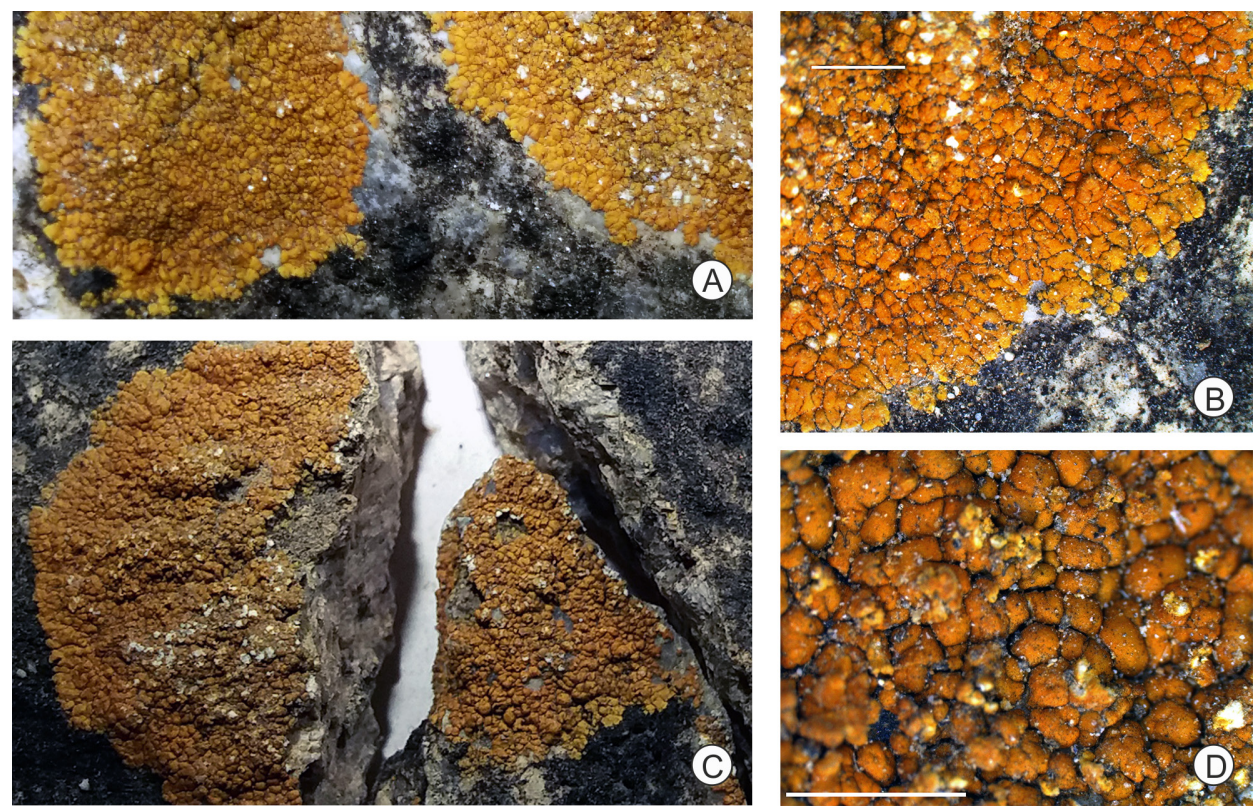

Fig. 1. Caloplaca rajasthanica (holotype, BSA), habitat (A-C), enlarged thalline portion (D). Scale: $2 \mathrm{~mm}(\mathrm{~B}, \mathrm{D})$

\footnotetext{
* Owing to the presence of lateral incisions, which are also typical for Caloplaca anularis or C. zeravshanica, thalline lobes often seem to be shorter.

${ }^{* *}$ However, it should be emphasised that naked white medulla in some spots of central portions of thallus can occur as bright whitish irregular soralia. Specimen 07007414 (LWG) was probably mechanically damaged years before collecting and overgrowing fragments at the edges of damaged portions partly developed to blastidia or schizidia.
} 
dia) usually absent. However, in the central areolate portion sometimes areole edges with rough or eroded surface to isidia- or soredia-like structures, while true soralia (i.e. small Caloplaca cupulifera-type soralia like in Fulgogasparrea awasthii), and soredia (i.e. uplifted soredious mass, like in Fulgogasparrea awasthii) absent. Apothecia and conidiomata not known, but apothecial primordia or conidiomata $0.2-0.25 \mathrm{~mm}$ diam. sometimes (BSA 7806) observed. Chemistry: Thallus K+ purple, KC-, C-, Pd-: parietin present in TLC (Fig. 5). Etymology: It is named after Rajasthan state of India, where type collection was made. Ecology and distribution: Saxicolous species growing along with Caloplaca cupulifera, Fulgogasparrea awasthii, Peltula sp. and Staurothele sp. between elevations of 560-1,357 m in Madhya Pradesh, Maharashtra, Jamma \& Kashmir and Rajasthan.

Taxonomic notes: In having sometimes lobate areoles in the peripheral zone with typical lateral incisions Caloplaca rajasthanica is similar to C. anularis Clauzade et Poelt, the species mainly known from mountainous regions of Europe, but differs in having mainly regularly rounded or rosette-like thalli entirely developed in the centre (vs. thallus mainly of curved 'arcs' of peripheral zone usually without central portion of thallus), in having mainly areolate thallus with distinct peripheral zone, i.e. radially orientated areoles or lobes in the peripheral zone and much thicker areoles in the centre (vs. lobate thallus where only radially orientated lobes are present), in having thalline areoles distinctly thinning towards the tips, and much thicker in the centre of thallus (vs. the thickness of thalline lobes is the same everywhere while they are rather thick towards the tips), as well as in having mainly an evenly coloured dull brownish yellow thallus (vs. orange or orange-yellow thalline lobes in the peripheral portions and whitish portions towards the centre). In having sometimes lobate areoles in the peripheral zone Caloplaca rajasthanica is similar to C. zeravshanica Kudratov et S. Y. Kondr., a Central Asian species known only from Tajikistan and China from limestone at high altitudes, but differs in having mainly regularly rounded or rosette-like thalli entirely developed in the centre (vs. thallus mainly of curved 'arcs' of peripheral zone usually without central portion of thallus), in having mainly areolate thallus with distinct peripheral zone, i.e. radially orientated areoles or lobes in the peripheral zone and much thicker areoles in the centre (vs. lobate thallus where aggregations of radially orientated lobes are present), in having thalline areoles distinctly thinning towards the tips, and much thicker in the centre of thallus (vs. the thickness of thalline lobes is the same everywhere while they are rather thick towards the tips), as well as in having mainly evenly coloured dull brownish yellow thallus (vs. ochre yellow or ochre orange, rarely reddish orange thalline lobes in the peripheral portions and whitish portions towards the centre). Caloplaca rajasthanica is similar to the endemic species Fulgogasparrea awasthii to which material of this species was previously included, but 
differs in having much larger and rosette-like or regularly rounded thalli with well-developed peripheral zone (to $1.5-3(-4) \mathrm{cm}$ vs. to $1 \mathrm{~mm}$ across, the same areolate throughout), in compact, film-like thallus (vs. consisting of distant areoles), in having areolate to lobate peripheral zone where areoles/lobes distinctly becoming thinner towards the tips, in having longer and wider thalline areoles/lobes in peripheral zone (to $3 \mathrm{~mm}$ long vs. to $2 \mathrm{~mm}$ long), in having much wider and distinctly thickened areoles in the central portion of thallus (to $1(-1.3) \mathrm{mm}$ across and to $1(-2) \mathrm{mm}$ thick vs. $0.3-0.5 \mathrm{~mm}$ wide and ca $0.2-0.3 \mathrm{~mm}$ thick), and in the lack of very small Caloplaca cupulifera-type soralia, and in the lack of uplifted soredious mass, while in having isidia-like or eroded surface along the areole edges sometimes, as well as in positioning in the Xanthorioideae after nrITS phylogeny while Fulgogasparrea is a member of the Teloschistoideae. In having somewhat dissected thalline lobes in peripheral portions as well as some dissected fragments $c a 0.1 \mathrm{~mm}$ across along the thalline lobes Caloplaca rajasthanica is similar to the Australian endemic species Squamulea kiamae (S. Y. Kondr. et Kärnefelt) Arup, Søchting et Frödén, but differs in having larger thalline lobes in peripheral zone, in having somewhat verruculose areolate central portion of the thallus, as well as in the lack of soredia/blastidia. After having convex, densely aggregated, thick thalline areoles in the centre of the thallus, Caloplaca rajasthanica can be similar to C. scrobiculata H. Magn., but differs in having smooth (not eroded) and somewhat slightly shiny or matt upper surface of thalline areoles (vs. upper surface totally eroded). Status of material with thin thallus throughout (not being thickened in the centre), but having distinct peripheral zone and differing in the lack of $C$. cupulifera-type soralia and uplifted soredious mass is still unclear. It is included here in C. rajasthanica with some hesitation. It is highly likely that it is an additional, still undescribed species of $C$. rajasthanica complex. Hopefully future molecular study of the Fulgogasparrea awasthii and C.
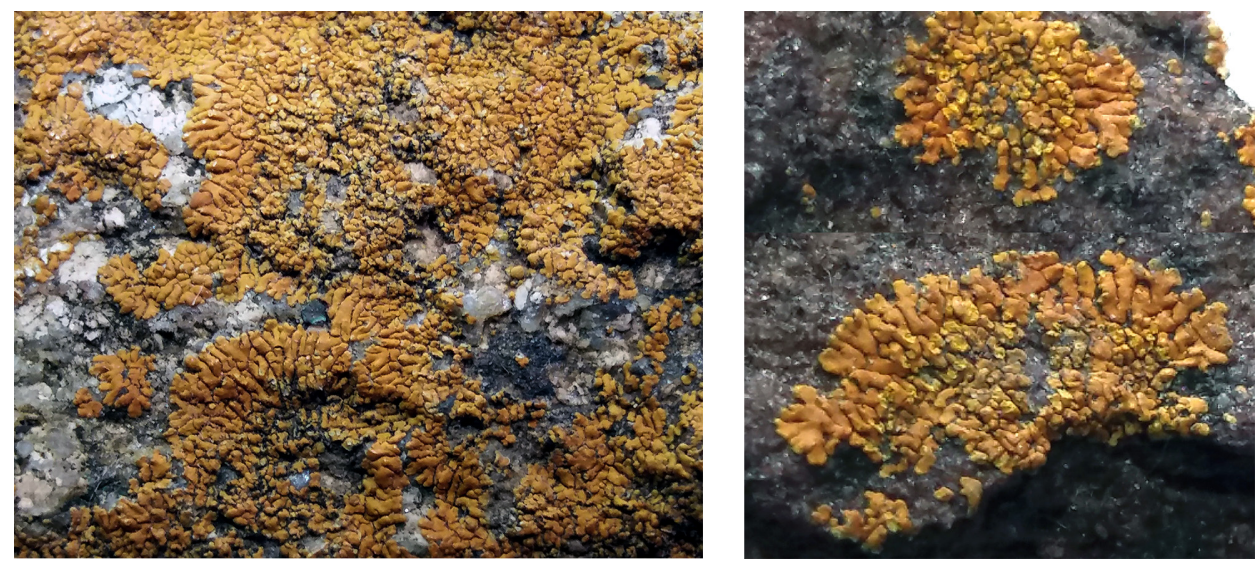

Fig. 2. Fulgogasparrea awasthii (holotype, BSA) habitat 
rajasthanica complexes will clarify the status of this material too. Based on our preliminary molecular data (based unfortunately only on a single voucher specimen), Caloplaca rajasthanica belongs to the complex of Asian taxa close to C. anularis/C. zeravshanica, which is positioned in a separate monophyletic branch of the Xanthorioideae on the basis of nrITS phylogeny. Unfortunately, nrITS data of the recently described species Caloplaca zeorina B. G. Lee et Hur from China (as well as on Calogaya qinghaiensis B. G. Lee et Hur) (Lee et al. 2018) are very partial, and for the final conclusion additional voucher specimens of Caloplaca anularis, C. zeravshanica and C. zeorina should be included in the molecular analysis. Furthermore, the final conclusion about the status of this species group will be drawn when data on nrLSU and $\mathrm{mtSSU}$ (as well as other genes, i.e. RPB2, RPB1, etc.) will be available for the taxa mentioned. It is positioned in the Xanthorioideae based on nrITS phylogeny.

Representative specimens examined: Madhya Pradesh, Dhar district, Mandav, on plaster, 20.01.2007, Joshi \& R. Bajpai, LWG-07-007409, LWG-07-007411, LWG-07-007414; Bhopal district, Mahaveer Giri, 18.02.2011, S. Mohabe \& K. K. Ingle, LWG-011-015323. - Maharashtra, Pune district, Pune City, on hill opposite NCLY, alt. 560 m, on rock, 27.03.2005, S. Nayaka, LWG-05-001871; Chatushragi Hill, alt. 560 m, on rock, 30.03.2005, Nayaka, LWG05-001886. - Jamma \& Kashmir, Srinagar district, Shankaracharya Hill, 05.1961, G. C. Rath, LWG-68.4. - Rajasthan, Kota district, Gapernath, $24^{\circ} 35^{\prime} 7.3^{\prime \prime}$ N, $72^{\circ} 47^{\prime} 52^{\prime \prime}$ E, on rock, 05.2013, S. Yadav, LWG-13-027219; Sirohi district, Mt Abu, Trevor's Tank, 14 38' 11.19" N, $72^{\circ} 45^{\prime}$ 29.85" E, alt. 1,357 m, on rock, 22.05.2013, S. Yadav, LWG-13-026404, Delwara Pond area, on exposed rocks, 23.05.2013, S. Yadav, LWG-13-022490, Sunrise Valley, 1,050 m, on

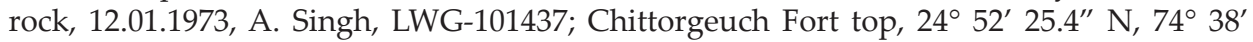
58.1" E, alt. 554 m, on rock, G. P. Sinha \& R. Kar, BSA-7959; Sikar, Harsh Mts, 27 29' 58.4" N, 75 10' 10.29" E, alt. 1,100 m, 02.01.2016, R. Kar, BSA-10173, BSA-10162.

Caloplaca rinodinopsis Poelt et Hinter., Bibl. Lichenol. 50: 189 (1993). The species is characterised by indistinct, greyish violet thallus; very small, 0.2-0.3 mm diam., lecanorine, Lecanora subfusca-type, dark brown to black apothecia; grey or greyish violet thalline margin with black disc; $12-19 \times 7-10 \mu \mathrm{m}$ ascospores, and 4-6.5 $\mu \mathrm{m}$ wide septum (Joshi 2008). Chemistry: Thallus and apothecial disc $\mathrm{K}-, \mathrm{KC}-, \mathrm{C}-$, $\mathrm{Pd}-$-: epihymenium $\mathrm{K}+$ purple: lichen substances not studied by TLC. Ecology and distribution: Corticolous species growing in association with Opeltia flavorubescens at an altitude of $1,800 \mathrm{~m}$ in temperate regions of Uttarakhand.

Representative specimen examined: Uttarakhand, Dehra Dun district, Mussoorie/Chakrata Hills, on the way to Bunkteshwar temple, alt. ca 1,800 m, on bark of tree, 24.10.1975, M. Joshi, LWG-LWU-75-219.

Caloplaca ruderum (Malbr.) J. R. Laundon, Lichenologist 8(2): 139 (1976). - Thallus pale yellow, areolate, areoles angular to roundish, somewhat constricted at the base, apothecia dispersed, about $1 \mathrm{~mm}$ diam., ascospores 14-20 $\times 6-8 \mu \mathrm{m}$ and septum very narrow, $1-2 \mu \mathrm{m}$ wide, often not completely closed. Chemistry: Thallus and apothecial disc $\mathrm{K}_{-}, \mathrm{KC}-, \mathrm{C}_{-}, \mathrm{Pd}-$; epihymenium $\mathrm{K}+$ 
purple: parietin present in TLC. Ecology and distribution: Saxicolous species growing on calcium containing siliceous rock along with Squamulea subsoluta, between altitudes of 1,900-2,100 $\mathrm{m}$ in temperate regions of Uttarakhand and Jammu \& Kashmir. Taxonomic notes: This species may belong to the genus Xanthocarpia, but molecular data are still missing.

Representative specimen examined: Uttarakhand, Pauri district, Srinagar, Government Inter College, on rocks, 18.06.2005, V. Shukla \& Y. Joshi, LWG-05-005248.

Caloplaca stillicidiorum (Vahl) Lynge, Skr. Vidensk Selsk. Christiania, Kl. I, Math.-Natur. 15: 4 (1921). = Caloplaca cerina var. chloroleuca (Sm.) Th. Fr., Lich. Scand. 1: 174 (1871). - The species is characterised by round to wavy (angular, owing to mutual pressure) apothecia and 0.3-1.0(-2.2) $\mathrm{mm}$ in diam., \pm pruinose, yellow to olivaceous green, concave to flat disc, proper margin absent, thalline margin thick, smooth to wavy, raised above the level of disc, concolorous with thallus, densely pruinose (Joshi 2008). Chemistry: Thallus $\mathrm{K}-, \mathrm{KC}-, \mathrm{C}-, \mathrm{Pd}-$; apothecial disc and epihymenium $\mathrm{K}+$ purple: parietin present in TLC. Ecology and distribution: It grows over mosses at an altitude of 4,500 m in Himachal Pradesh.

Representative specimen examined: Himachal Pradesh, Lahul Spiti district, Spiti valley, Kunzum Pass, alt. 4,500 m, on soil, 03.08.2002, D. K. Upreti \& P. K. Divakar, LWG02-000081/C.

Caloplaca subbassiae Y. Joshi et Upreti, Nova Hedwigia 86(1-2): 270 (2008). - This species is characterised by a continuous to \pm areolate yellow thallus with branched to coralloid isidia, inspersed hypothecium, and an amphithecium with algal cells (Joshi 2008). Chemistry: Thallus, isidia, apothecial disc, thalline margin and epihymenium $\mathrm{K}+$ purple, $\mathrm{KC}-$, $\mathrm{C}-$, $\mathrm{Pd}-$ : parietin, and an additional pale yellow spot at Rf 5 and olive-green spot between $\mathrm{Rf}$ 2-3 present in TLC. Ecology and distribution: The species grows on noncalcareous rocks between altitudes of $600-900 \mathrm{~m}$ in tropical to subtemperate regions of Madhya Pradesh and Uttarakhand. Taxonomic notes: This species may belong to the genus Oxneriopsis, but molecular data should be obtained for confirmation of its position.

Representative specimens examined: Madhya Pradesh, Dindori district, Near Kabir, alt. 1,400 m, on rock, 08.07.2005, D. K. Upreti, S. Nayaka \& Satya, LWG-05-005810. - Uttarakhand, Champawat district, Chalthi on the way to Tankpur, alt. $750 \mathrm{~m}$, on rock, 29.11.2010, G. K. Mishra, LWG-10-015242; Pati on the way to Dunaghat, alt. 1,700 m, on rock, 28.11.2010, G. K. Mishra, LWG-10-015393, LWG-10-015382.

Caloplaca subdolosa (Nyl.) Zahlbr., Cat. Lich. Univ. 7: 184 (1931). - This species is distinguished by the lecanorine apothecia (with thalline margin), pale brown apothecial disc, $\mathrm{K}$-epithecium, and 10-14 $\times 7-8 \mu \mathrm{m}$ ascospores (Awasthi 1991). Chemistry: Thallus and soredia K+ purple, KC-, C-, Pd-: parietin present in TLC. Ecology and distribution: Saxicolous species having a restricted distribution in Karnataka and Uttarakhand. 
Representative specimens examined: Uttarakhand, Almora district, Takula, alt. 1,950 m, on rock, 13.05.1950, D. D. Awasthi \& A. M. Awasthi, LWG-AWAS-555; Pithoragarh district, Gori-Ganga Catchment, East Ghandhura, alt. 1,300-1,700 m, on rock, 02.10.2002, V. Pant, LWG-02000827, LWG-02000831.

Caloplaca subleptozona Y. Joshi et Upreti, Lichenologist 40(6): 538 (2008). - This species is generally characterised by UV+, cracked-areolate to rimose-areolate cream to yellowish white to beige-greyish thallus, surrounded by a black prothallus and \pm pruinose constricted apothecia (Joshi 2008). Chemistry: Thallus $\mathrm{K}+$ yellow, $\mathrm{KC}-, \mathrm{C}-, \mathrm{Pd}-, \mathrm{UV}+$ yellow; apothecial disc and epihymenium $\mathrm{K}+$ purple, $\mathrm{C}-$, $\mathrm{Pd}-$ : atranorin, triterpenes at Rf class 3 and 7 along with UV+ yellow spots developed after charring between Rf 3 to 7 in solvent system A, while, parietin and triterpenes at Rf 2, 3 and 6 occurs in solvent system B. Likewise solvent system A, UV+ yellow spots are noticed between Rf 3 to 7 after charring in solvent system B (Joshi 2008). Ecology and distribution: Saxicolous species, it occurs in inland areas between altitudes of $1,000-1,800 \mathrm{~m}$ in tropical to temperate regions of Himachal Pradesh, Rajasthan and Uttarakhand.

Representative specimens examined: Himachal Pradesh, Kangra district, Macleodganj, alt. 1,600-1,800 m, on rock, 13.05.2001, D. K. Upreti \& S. Nayaka, LWG-0175249. Rajasthan, Sirohi district, Mt Abu, alt. 1,200-1,350 m, on rock, 16.09.1985, D. D. Awasthi \& G. Awasthi, LWG-LWU-85.58. - Uttarakhand, Nainital district, Jim Corbett Tiger Reserve, near Mohan, on vertical side of rock at road, 18.03.1999, D. K. Upreti, LWG-L65006 (holotype: LWG; isotype: CAL); Pithoragarh district, Gori-Ganga Catchment, Bangapani, alt. 1,000-1,300 m, on rock, 01.10.2002, V. Pant, LWG-02-000750.

Caloplaca transcaspica (Nyl.) Zahlbr.*, Cat. Lich. Univ. 7: 189 (1931). The species is mainly characterised by dirty whitish, areolate to squamulose thallus with distinct black, immersed to sessile apothecia and $\mathrm{K}+$ violet epihymenium (Joshi 2008). Chemistry: Thallus and apothecial disc K-, KC-, C-, $\mathrm{Pd}-$; epihymenium $\mathrm{K}+$ brinjal (eggplant) coloured (bluish black/dark purple) or slightly $\mathrm{K}+$ purple, $\mathrm{C}-$, Pd-, I+ blue: no chemicals present in TLC. Ecology and distribution: Saxicolous species growing on more or less calcareous rock in semiarid mountains, widely distributed in Himachal Pradesh. Taxonomic note: This is a member of the Pyrenodesmia branch of the phylogenetic tree of the Teloschistaceae.

Representative specimen examined: Himachal Pradesh, Kangra district, Karchu (= Chota Shigri), 13.08.1952, O. A. Höeg, LWG-AWAS-1704.

Caloplaca triloculans Zahlbr., in Hand.-Mazz., Symb. Sin. 3: 219 (1930). This species is characterised by continuous, thin, smooth, glossy, whitish grey thallus, black prothallus, reddish brown to brown apothecial disc, smooth to wavy thalline margin, parathecium of radiating elongated hyphal cells, amphithecium with algae, outer surface with hyaline crystals, ascospores trilocu-

* It is currently shown that this species is a member of the genus Pyrenodesmia. 
lar, middle locule elongated and bigger than polar locules (Joshi 2008). Chemistry: Thallus and apothecial disc and epihymenium $\mathrm{K}-, \mathrm{KC}-, \mathrm{C}-, \mathrm{Pd}-, \mathrm{UV}+$ orange: lichen substances not studied by TLC. Ecology and distribution: It grows on Quercus incana bark at an elevation of 1,950 $\mathrm{m}$ in Uttarakhand.

Representative specimen examined: Uttarakhand, Dehra Dun district, Mussoorie Hills, on the way to Bunkteshwar temple, alt. ca 1,950 m, on Quercus bark, 24.10.1975, M. Joshi, LWG-LWU-75-249.

Caloplaca tropica Y. Joshi et Upreti, Lichenologist 39(6): 505 (2007). - This species is characterised by an indistinct grey thallus, orange to orange brown apothecial discs with prominent black proper margin and narrowly ellipsoid ascospores with very narrow septa (Joshi 2008). Chemistry: Thallus K-, KC-, $\mathrm{Pd}-$; apothecial disc and epihymenium $\mathrm{K}+$ purple, $\mathrm{C}-$, $\mathrm{Pd}-$ : parietin and olive spot at Rf 4 present in TLC. Ecology and distribution: It grows on sun exposed quartzite rocks in association with Buellia sp., Caloplaca poliotera, C. orissensis and Neobrownliella cinnabarina, between altitudes of 500-600 $\mathrm{m}$ in more or less dry tropical regions of Madhya Pradesh, Maharashtra and Uttar Pradesh.

Representative specimens examined: Madhya Pradesh, Katni district, Khitauli, on exposed siliceous rock, 20.02.2009, G. K. Mishra \& S. Mohabe, LWG-09-009983/D; Panna district, Badorshiha, near diamond mine, on exposed rock, 06.12.2009, S. Mohabe \& G. K. Mishra, LWG-09-012856/B; Rewa district, Bahuti, Mauganj, on exposed siliceous rock, 17.02.2009, G. K. Mishra \& S. Mohabe, LWG-09-009163/B, LWG-09-009161. - Maharashtra, Pune city, Taljai, Parvati Paschgaon, alt. 580 m, on rock, 31.01.2006, S. Nayaka, LWG-06005066. - Uttar Pradesh, Mirzapur district, Shivpur Hills, 6 km from Mirzapur city, alt. ca 500-600 m, on rocks of open area, 03.02.1980, D. K. Upreti \& U. C. Misra, LWG-LWU-80.604, LWG-LWU-80.605.

\section{Flavoplaca Arup, Søchting et Frödén}

Type: Flavoplaca citrina (Hoffm.) Arup, Frödén et Søchting

The genus Flavoplaca comprises 28 species from the world (Arup et al. 2013), while three species occur in India.

1 Thallus distinctly lobate in peripheral portion

F. granulosa

- Thallus areolate or squamulose

2 Thallus areolate, somewhat squamulose or with some flat lobes, surface usually flat, soralia covering $10-50 \%$ of thallus, marginal, often on slightly lifted margin

F. flavocitrina

- Thallus areoles flat to convex, sometimes squamulose or lobe-like, soredia irregular, sometimes initiating at margin but spreading irregularly, partly to completely covering the thallus

F. citrina 
Flavoplaca citrina (Hoffm.) Arup, Frödén et Søchting, Nordic J. Bot. 31(1): 44 (2013). - This species is characterised by its orange colour, completely sorediate or unlobed flat areoles with soredia arising marginally, which sooner cover most or all of the thallus (Joshi 2008). Chemistry: Thallus and soredia $\mathrm{K}+$ purple, $\mathrm{KC}-, \mathrm{C}_{-}, \mathrm{Pd}-, \mathrm{I}-$ : parietin present in TLC. Ecology and distribution: Saxicolous species growing in temperate to subalpine regions of Jammu \& Kashmir, Madhya Pradesh, Maharashtra, Tamil Nadu and Uttarakhand between altitudes of 1,350-2,900 m.

Representative specimens examined: Uttarakhand, Bageshwar district, Pindari Glacier; on the way to Phurkia from Dwali, on rock, Y. Joshi \& S. Joshi, LWG-07-10098; Nainital district, Bhimtal, alt. 1,350 m, on rock, 06.11.1967, A. Singh, LWG-91147; Pithoragarh district, Sandev Botanical Hot Spot, alt. 1,700-2,050 m, on rock, 28.09.2002, V. Pant, LWG-02000955; Gori-Ganga Catchment, East Ghandhura, alt. 1,600-2,000 m, on rock, 03.10.2002, V. Pant, LWG-02-000847.

Flavoplaca flavocitrina (Nyl.) Arup, Frödén et Søchting, Nordic J. Bot. 31(1): 45 (2013). - The species is characterised by a yellowish orange areolate thallus, pale soredia arising marginally, zeorine apothecia, with a yellowish orange to orange disc, inspersed hypothecium and presence of oil in paraphyses (Joshi 2008). Chemistry: Thallus and apothecial disc K+ purple, KC-, C-, Pd-: parietin and olive-green spot at Rf 4 present in TLC. Ecology and distribution: Saxicolous species growing on exposed rocks at elevations of 2,000-3,200 $\mathrm{m}$ in temperate regions of Himachal Pradesh, Jammu \& Kashmir and Uttarakhand.

Representative specimen examined: Jammu \& Kashmir, Anantnag district, Pahalgam, W side near Hotel Heevan, alt. 2,000 m, on rocks, 30.07.2005, M. Sheikh, LWG-05-034679.

Flavoplaca granulosa (Nyl.) Arup, Frödén et Søchting, Nordic J. Bot. 31(1): 45 (2013). - This species is characterised by a very thin, continuous, grey thallus, black prothallus, discrete, orange mounding up soralia of $0.1-0.2 \mathrm{~mm}$ diam., yellowish to orange-yellow soredia (Joshi 2008). Chemistry: Thallus $\mathrm{K} \pm$ purple (in yellowish regions), $\mathrm{KC}-, \mathrm{C}-$, $\mathrm{Pd}-$; soredia $\mathrm{K}+$ purple: lichen substances not studied by TLC. Ecology and distribution: Corticolous species occurring in temperate region of Uttarakhand between altitudes of 2,400-2,550 m.

Representative specimen examined: Uttarakhand, Dehra Dun district, Mussoorie/ Chakrata Hills, on the way to Deoban, alt. 2,400-2,550 m, on bark, D. D. Awasthi \& M. Joshi, LWG-LWU-76-54.

\section{Fulgogasparrea S. Y. Kondr., M.-H. Jeong, Kärnefelt, Elix, A. Thell et J.-S. Hur}

Type: Fulgogasparrea decipioides (Arup) S. Y. Kondr., M.-H. Jeong, Kärnefelt, Elix, A. Thell et J.-S. Hur

The genus Fulgogasparrea comprises three species in the world (Kondratyuk et al. 2013a) and one species occurs in India. 
Fulgogasparrea awasthii (Y. Joshi et Upreti) S. Y. Kondr., Upreti et A. Thell, comb. nova (Figs 2, 7) - MycoBank No.: MB 832435 - Basionym: Caloplaca awasthii Y. Joshi et Upreti, Bot. J. Linn. Soc. 155: 149 (2007). Type: India, Madhya Pradesh, Raisen district, Bhimbetika, Rang Mahal, alt. 500 m, on rock, 02.11.2004, Joshi 04-004539 (holotype: LWG; isotype: CAL). - The species is characterised by effigurate to \pm subsquamulose, central portion lobed to \pm areolate thallus, yellow-orange to orange-red, plane to subconvex lobes, fine to coarse blastidia concolorous with thallus, apothecia and pycnidia are lacking. Chemistry: Thallus $\mathrm{K}+$ purple, $\mathrm{KC}-, \mathrm{C}-, \mathrm{Pd}-$ : parietin and pale greenish blue spot at Rf 4 present in TLC. Ecology and distribution: Saxicolous species growing on vertical surfaces of sandstones (non-calcareous rocks) in tropical to subtropical regions of Madhya Pradesh and Rajasthan between altitudes of 500-1,050 m in association with Caloplaca cupulifera, C. rajasthanica and Squamulea in Rajasthan, whereas in Madhya Pradesh the species is associated with Dimelaena thysanota, Megaspora subpoliotera, Peltula euploca, Squamulea subsoluta and Staurothele spp. Taxonomic notes: Isotype and paratypes of Fulgogasparrea decipioides (Arup) S. Y. Kondr., M. H. Jeong, Kärnefelt, Elix, A. Thell et Hur have been found to be more or less homogeneous, while within the specimens collected after 2004 a new species Caloplaca rajasthanica S. Y. Kondr., Upreti et G. P. Sinha was segregated.

Representative specimens examined: Madhya Pradesh, Raisen district, Bhimbetka, Mane Cave area, on rock, 10.10.2004, D. K. Upreti \& Y. Joshi, LWG-04-004456, Rang Mahal area, on rock, 11.2004, Y. Joshi, LWG-04-004539, Rang Mahal area, on rock, 11.07.2004, D. K. Upreti, LWG-04-003517; Jabalpur district, Bedinagar Hills, $11 \mathrm{~km}$ away from Jabalpur city, alt. ca $500 \mathrm{~m}$, on rock in open area, 25.01.1980, D. K. Upreti \& S. Mishra, LWU-LWG-80-318.

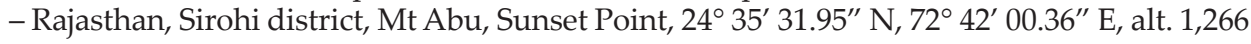
m, on rock, 22.05.2013, S. Yadav, LWG-13-026408; Near Delwara Pond, 24 36' 40.17" N, $72^{\circ}$ $44^{\prime}$ 04.26" E, alt. 1,165 m, on rock, 23.05.2013, S. Yadav LWG-13-026404/B; Trevor's Tank, $24^{\circ}$ $38^{\prime} 11.19^{\prime \prime} \mathrm{N}, 72^{\circ} 45^{\prime} 29.85^{\prime \prime}$ E, alt. 1,357 m, on rock, 22.05.2013, S. Yadav, LWG-13-026404.

\section{Gallowayella S. Y. Kondr., Fedorenko, S. Stenroos, Kärnefelt, Elix et A. Thell}

Type: Gallowayella gallowayi (S. Y. Kondr. et Kärnefelt) S. Y. Kondr., Fedorenko, S. Stenroos, Kärnefelt, Elix, J.-S. Hur et A. Thell

About 16 species of the genus are known in the world (Fedorenko et al. 2012), two species are known from India.

1 Rhizines usually distinct, clearly seen, lobes strip-like, horizontal oriented, narrower than $0.3 \mathrm{~mm}$ wide, soralia micro-huculica type

G. awasthiana

- $\quad$ Rhizines usually absent, lobes vertically oriented or ascending erect, $0.5-$ $1 \mathrm{~mm}$ wide, soralia marginal \pm crescent shape

G. fulva 
Gallowayella awasthiana S. Y. Kondr. et Upreti, Acta Bot. Hung. 60(1-2): 141 (2018). - This species is characterised by the small thallus, rather long and narrow, and mostly horizontally orientated thalline lobes, very long and easily distinct rhizines, micro-huculica type soralia, small soredia, large apothecia, and narrow ascospores septum (Kondratyuk et al. 2018b). Chemistry: Thallus $\mathrm{K}+$ purple, $\mathrm{KC}-, \mathrm{C}-$, $\mathrm{Pd}-$, I-: parietin, fallacinal, emodin, teloschistin and parietinic acid present in TLC. Ecology and distribution: Corticolous species growing in association with Caloplaca aff. cerina aggr., Candelaria cf. concolor, Lecidella, Phaeophyscia, and Physcia spp. between elevations of 2,000-3,301 m in Jammu \& Kashmir and Uttarakhand. Taxonomic notes: Previous records of Oxneria ulophyllodes may belong to this species. This is why all specimens of $O$. ulophyllodes should be verified especially from this point of view.

Representative specimens examined: Uttarakhand, Chamoli district, Badrinath, Mana village, on twigs, 21.06.2005, V. Shukla \& Y. Joshi, LWG-05-005210/B, LWG-05-005210; on Juglans regia bark, 21.06.2005, V. Shukla \& Y. Joshi, LWG-05-005309, LWG-05-005428; on rocks, 21.06.2005, V. Shukla \& Y. Joshi, LWG-05-004970, LWG-05-004974, LWG-05-005371, LWG-05-005381, LWG-05-005959.

Gallowayella fulva (Hoffm.) S. Y. Kondr., Fedorenko, S. Stenroos, Kärnefelt, Elix, J.-S. Hur et A. Thell, Bibl. Lichenol. 108: 57 (2012). - The species is characterised by marginal \pm crescent-shaped soralia occurring at the tips of slightly raised lobes and paraphyses with oil globules (Joshi 2008). Chemistry: Upper surface K+ purple, C-, Pd-, I-: parietin, fallacinal, emodin, teloschistin and parietinic acid present in TLC. Ecology and distribution: It grows in open to semi-open habitats, but also in \pm shady areas on bark, rarely on rocks in Jammu \& Kashmir.

Representative specimens examined: Jammu \& Kashmir, Anantnag district, Baltal, alt. 2,700 m, on bark, 13.09.1982, A. Singh \& D. K. Upreti, LWG-11674; Baramulla district, Gulmarg, alt. 2,700 m, on bark, 12.09.1982, A. Singh \& D. K. Upreti, LWG-11668; W side, alt. 2,570 m, on trunk of Cedrus deodara, 24.07.2005, M. Sheikh, LWG-05-006695.

\section{Golubkovaea S. Y. Kondr., Kärnefelt, Elix, A. Thell et J.-S. Hur}

Type: Golubkovaea trachyphylla (Tuck.) S. Y. Kondr., Kärnefelt, Elix, A. Thell, J. Kim, M.-H. Jeong, N.-N. Yu, A. S. Kondratiuk et J.-S. Hur

A single species of the genus Golubkovaea is reported in the world (Kondratyuk et al. 2014a), present also in India. Originally it was described as Golubkovia (Kondratyuk et al. 2014a), but later was corrected to Golubkovaea (Ahti et al. 2015), because it was named after a female researcher, Nina Golubkova (LE, Russia).

Golubkovaea trachyphylla (Tuck.) S. Y. Kondr., Kärnefelt, Elix, A. Thell, J. Kim, M.-H. Jeong, N.-N. Yu, A. S. Kondr. et J.-S. Hur, Acta Bot. Hung. 56(12): 164 (2014). - The species is mainly characterised by closely adnate dark orange thallus composed of verruculose rather rough convex lobes, anticlinally 
arranged hyphae in the cortex and lacking lower cortical layer (Joshi 2008). Chemistry: Thallus, apothecial disc and epihymenium $\mathrm{K}+$ purple, $\mathrm{KC}-, \mathrm{C}-$, $\mathrm{Pd}-$ : parietin present in TLC. Ecology and distribution: Saxicolous species growing on calcareous rocks at an altitude of 3,600 m in Himachal Pradesh.

Representative specimen examined: Himachal Pradesh, Kangra district, Kaze, alt. 3,600 m, on calcareous rocks and boulders, 09.08.1952, O. A. Höeg, LWG-AWAS-1650.

Huneckia S. Y. Kondr., Elix, Kärnefelt, A. Thell et J.-S. Hur

Type: Huneckia pollinii (A. Massal.) S. Y. Kondr., Elix, Kärnefelt, A. Thell, J. Kim, A. S. Kondratiuk et J.-S. Hur

The genus Huneckia is represented by two species in the world (Kondratyuk et al. 2014a) and one of them is present in India.

Huneckia pollinii (A. Massal.) S. Y. Kondr., Elix, Kärnefelt, A. Thell, J. Kim, A. S. Kondratiuk et J.-S. Hur, Acta Bot. Hung. 56(1-2): 111 (2014). - This species is characterised by a thin continuous to areolate, grey to grey-green thallus, brown to rust-brown to black apothecial disc, parathecium of radiating thick-walled hyphae, amphithecium without algae and ascospores with thickened end walls (Joshi 2008). Chemistry: Thallus K-, KC-, C-, Pd-; apothecial disc and epihymenium K+ purple: parietin present in TLC. Ecology and distribution: Corticolous species growing along with Lecanora spp., Lecidea spp. and Graphis spp. at an altitude of $800 \mathrm{~m}$ in Karnataka and Orissa.

Representative specimens examined: Karnataka, Banglore district, Lalbagh garden, on Plumeria alba bark, 28.04.1979, D. D. Awasthi, D. K. Upreti \& U. C. Misra, LWG-LWU-79.102. - Orissa, Ganjam district, Berhampur University Campus, near guest house, on spiny shrub, 01.03.1986, D. D. Awasthi, G. Awasthi, R. Mathur \& P. Srivastava, LWG-LWU-86.030.

\section{Huriella S. Y. Kondr. et Upreti}

Type: Huriella loekoesiana S. Y. Kondr. et Upreti

Three species of the genus Huriella are hitherto reported in the world (Ekanayaka et al. 2019, Kondratyuk et al. 2017a, 2018b). An additional species new to science is described from India.

Huriella upretiana S. Y. Kondr., G. K. Mishra, Nayaka et A. Thell, spec. nova (Figs 3-5)

MycoBank No.: MB 832436

Similar to Huriella loekoesiana, but differs in having thicker apothecia (in section), higher hymenium, thicker subhymenium, longer and especially wider ascospores. 
Type: India, Jammu \& Kashmir, Jammu district, Natta Top, lat.: $33^{\circ} 05^{\prime} 33.6^{\prime \prime} \mathrm{N}$, long.: $75^{\circ} 16^{\prime} 29.5^{\prime \prime}$ E, alt. 2,440 m, on bark, 20.11.2017, S. Nayaka, S. Joseph, J. Raval \& P. Randive, LWG-17-030874 (holotype).

Thallus rather small, crustose, distinct of numerous more or less aggregated apothecia or seen as irregularly developed areoles or thalline portions to $0.15-0.25(-0.4) \mathrm{mm}$ long/across around apothecia, sometimes somewhat elongated to $0.35 \times 0.15 \mathrm{~mm}$, rarely somewhat radiating (seen at the highest magnification ( $\mathrm{ca}$ 120×) of stereo microscope), dull brownish yellow. In section thallus to (64-)80-112(-128) $\mu \mathrm{m}$ thick (while in rock cracks or rock undulations or if overlapping thalline portions, up to $240(-400) \mu \mathrm{m}$ thick); cortical layer (10-)24-32 $\mu \mathrm{m}$ thick, paraplectenchymatous, algal layer to 32-40 $\mu \mathrm{m}$ thick, algal cells 8-19.2 $\mu \mathrm{m}$ diam.; medullary layer more or less compact, with hyphae to $11-13 \mu \mathrm{m}$ thick in places observed. Apothecia $0.2-0.3(-0.45)[-0.54]$ $\mathrm{mm}$ diam., and to $0.2-0.27 \mathrm{~mm}$ thick in section; immersed into the thalline areoles at first, biatorine, to sessile, very often disc is plane, dull brownish, own margin 0.05-0.07(-0.1) mm wide, dull yellow, usually brighter than the thallus (dull brownish yellow) and the disc of apothecia. In section lecanorine
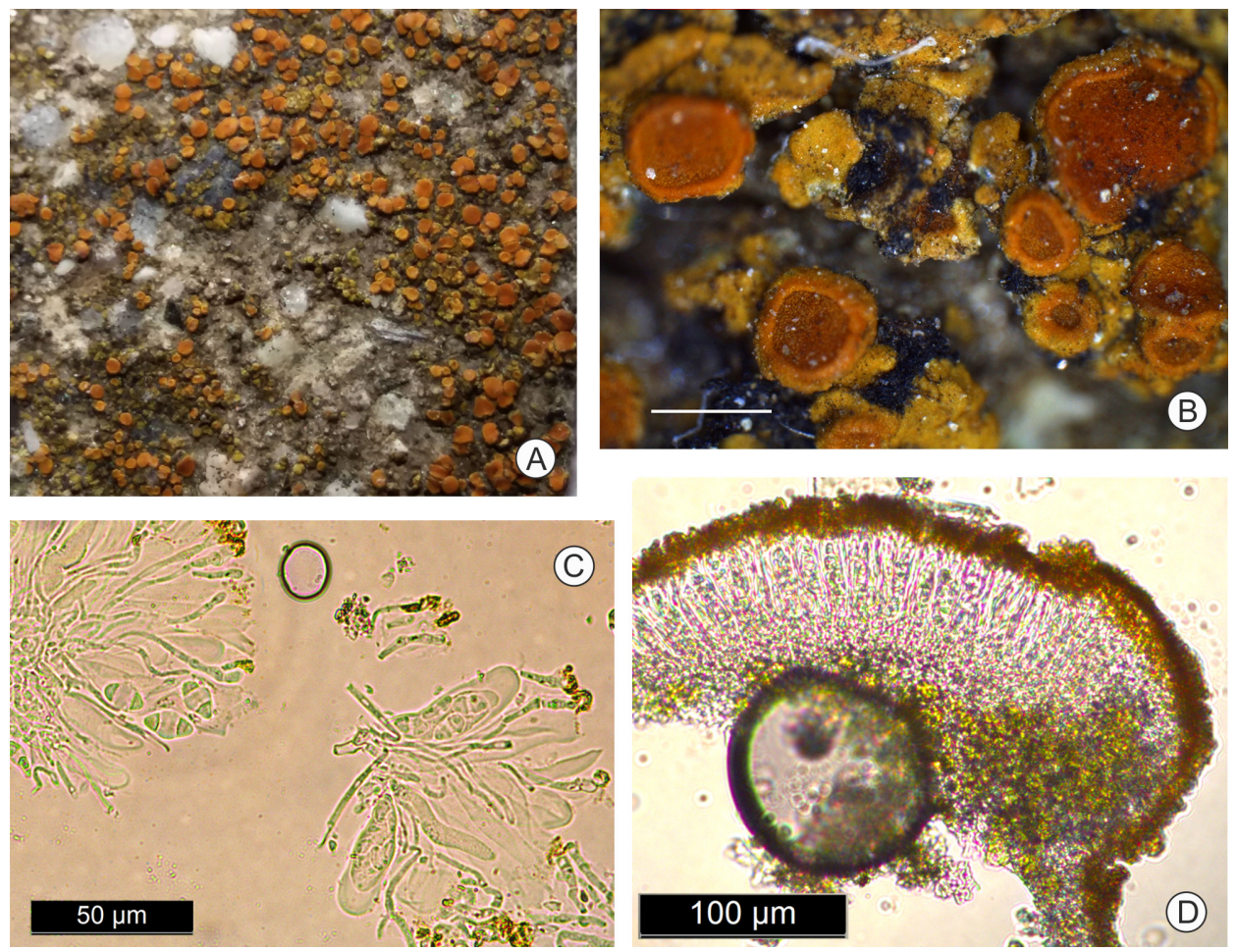

Fig. 3. Huriella upretiana (holotype, LWG): habitat (upper left), enlarged portion with apothecia (scale $1 \mathrm{~mm}$ ), section of apothecium (scale $100 \mu \mathrm{m}$ ), asci and ascospores (scale $50 \mu \mathrm{m}$ ) 
or zeorine, thalline exciple to 65-90(-128) $\mu \mathrm{m}$ thick, with very thin (9.6-)11-12 $\mu \mathrm{m}$ thick cortical layer and densely packed by algal cells, algal cell to 20-24 $\mu \mathrm{m}$ diam.; true exciple well developed only in uppermost lateral portion, 40 $80(-96) \mu \mathrm{m}$ thick, cells rounded to $5-7 \mu \mathrm{m}$ across, more or less rounded or vertically elongated, while in lower lateral and basal portion very indistinct, if present 12-16(-32) $\mu \mathrm{m}$ thick, Blastenia-type (Kondratyuk et al. 2014a); hymenium to 80-96 $\mu \mathrm{m}$ high, paraphysis tips to $4.0-4.8 \mu \mathrm{m}$ diam.; subhymenium 80112(-144) $\mu \mathrm{m}$ thick, paraplectenchymatous sensu Wetmore, sometimes with oil droplets to $1.6 \mu \mathrm{m}$ diam. in the upper portions; asci often with ascospores

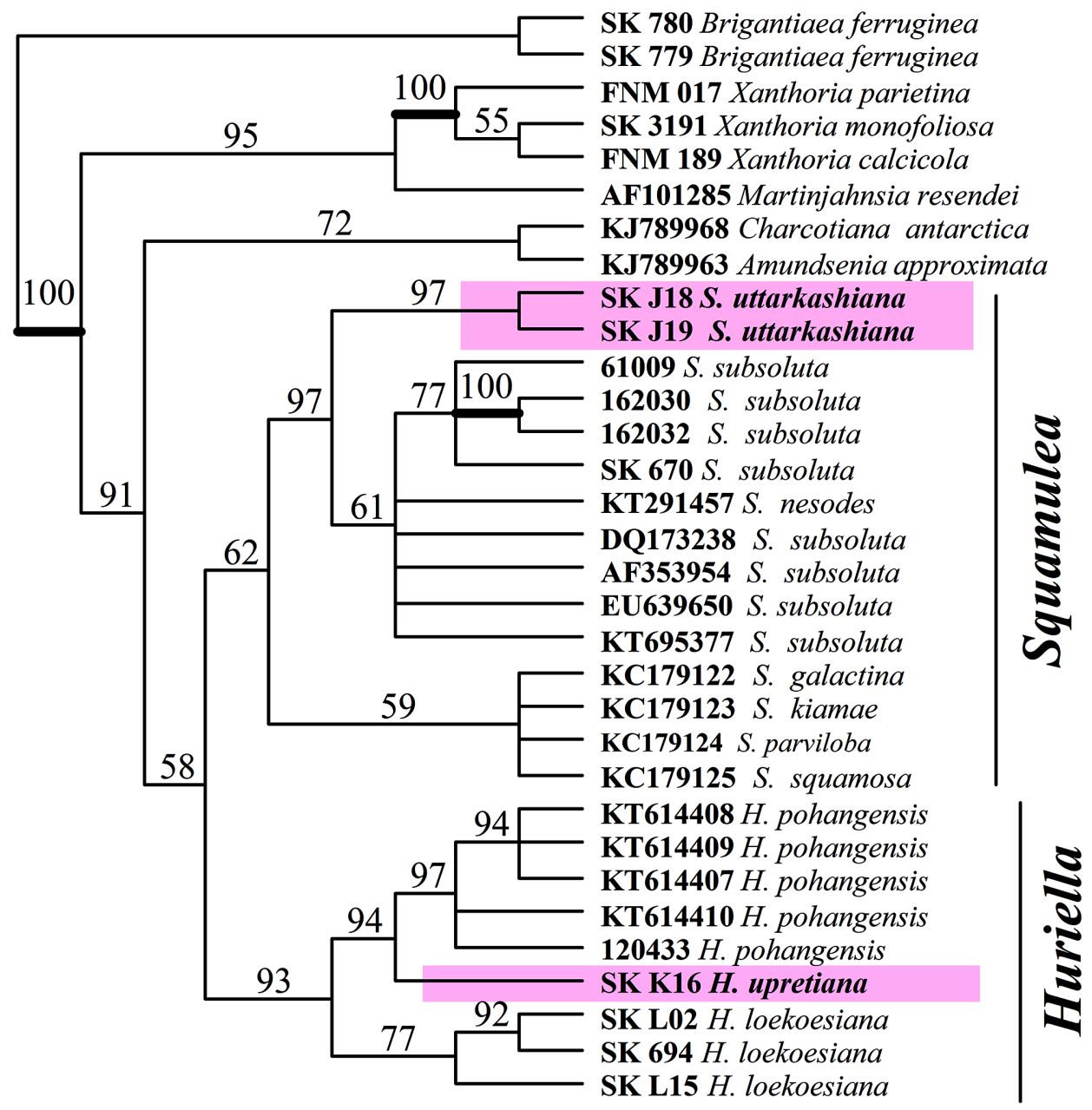

Fig. 4. Position of Huriella upretiana and Squamulea uttarkashiana in phylogenetic tree of the subfamily Xanthorioideae of the Teloschistaceae based on nrITS sequences 
of various size, ascospores widely ellipsoid (10.4-)12.8-14.4 × (6.4-)7.2-8(-9.6) $\mu \mathrm{m}$ in water and (9.6-)11.2-12.8(-14.4) × (6.4-)8.0-8.8(-9.6) $\mu \mathrm{m}$ in $\mathrm{K}$; ascospore septum well developed, (2.4-)3.2-4.0(-4.8) $\mu \mathrm{m}$ wide in water and (3.2-)4.04.8(-5.6) $\mu \mathrm{m}$ in K. Chemistry: Thallus, outermost portions of apothecium section $\mathrm{K}+$ purple; true exciple in outermost portions and epihymenium more or less blackish purple in places. Chemistry not studied further by TLC (Fig. 5). Etymology: It is named after the well-known Indian lichenologist Dr Dalip Kumar Upreti (LWG, Lucknow, India) for his numerous contributions to Indian lichenology. Ecology and distribution: It is rather common in various parts of the Indian subcontinent growing on siliceous rock between altitudes of 1,500-2,145 m in regions of Manipur, Jammu \& Kashmir, Madhya Pradesh and Uttarakhand.

Taxonomic notes: Huriella upretiana, recognised as dull brownish yellow spots owing to numerous more or less aggregated apothecia, is similar to $H$. loekoesiana S. Y. Kondr. et Upreti, but differs in having much thicker cortical layer of the thallus (24-32 $\mu \mathrm{m}$ vs. 10-15 $\mu \mathrm{m}$ thick), while thickness of the thallus is almost the same [(64-)80-112(-128) $\mu \mathrm{m}$ vs. $(60-) 70-100(-120) \mu \mathrm{m}$ thick],

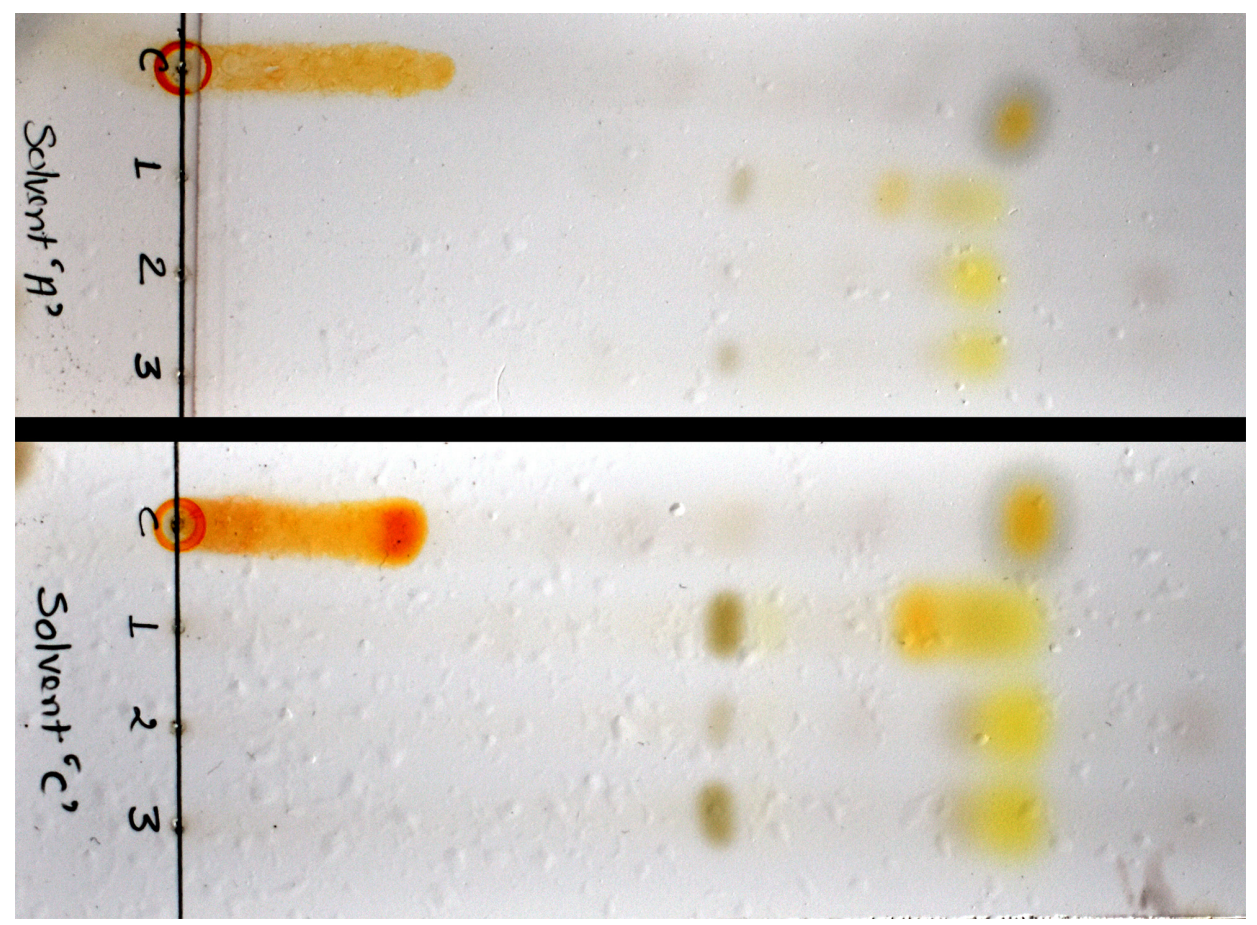

Fig. 5. TLC plate run in solvent systems ' $\mathrm{A}$ ' and ' $\mathrm{C}$ ': $1=$ Caloplaca rajasthanica, 2 = Squamulea uttarkashiana, 3 = Huriella upretiana 
in having thicker apothecia (0.32 $\mathrm{mm}$ vs. $0.2 \mathrm{~mm}$ thick in section), in having higher hymenium $(80 \mu \mathrm{m}$ vs. 50-60 $\mu \mathrm{m}$ high), in having thicker subhymenium (80-112 $\mu \mathrm{m}$ vs. $20-30 \mu \mathrm{m})$, and in having longer and especially wider ascospores [(10.4-)12.8-14.4 × (6.4-)7.2-8(-9.6) $\mu \mathrm{m}$ vs. $(8-) 10-12(-13) \times(4.5-) 5-6$ $\mu \mathrm{m}]$. From two other recently described East Asian species of the genus Huriella, i.e. H. pohangensis S. Y. Kondr., L. Lőkös et J.-S. Hur and H. salyangiana S. Y. Kondr. et J.-S. Hur (Kondratyuk et al. 2018b), which are characterised by much smaller ascospores, $H$. upretiana differs in having much longer ascospores, as well as in having larger apothecia. Huriella upretiana is similar to Squamulea subsoluta (Nyl.) Arup, Søchting et Frödén, but differs in having smaller thalline areoles $(0.15-0.25(-0.4) \mathrm{mm}$ vs. $0.4-2.5 \mathrm{~mm}$ wide), in having lecanorine or zeorine apothecia (vs. biatorine), and in having longer and wider ascospores $(10.4-) 12.8-14.4 \times(6.4-) 7.2-8(-9.6) \mu \mathrm{m}$ vs. 9.5-12.5(-14) × 5.5-7 $\mu \mathrm{m})$ (Kondratyuk et al. 2017a, 2018b). Huriella upretiana is similar to Squamulea squamosa (B. de Lesd.) Arup, Søchting et Frödén, but differs in having smaller thalline areoles $(0.15-0.25(-0.4) \mathrm{mm}$ vs. $0.4-2.5 \mathrm{~mm}$ wide), and in having longer and wider ascospores (10.4-)12.8-14.4 × (6.4-)7.2-8(-9.6) $\mu \mathrm{m}$ vs. (9.5-)11-12.5(-14) $\times 5.5-7 \mu \mathrm{m})$. Sometimes old overgrowing apothecia to $0.55 \mathrm{~mm}$ diam. of Huriella upretiana are observed with somewhat uplifted edges. They may resemble squamulose thallus, while thalline areoles are very small and closely attached to the substrate (not uplifted at the edges and not squamulose). It is interesting that Huriella upretiana is characterised by rather long ascospores in water, which become somewhat shorter in $\mathrm{K}$. This is observed for a member of the Teloschistaceae for the first time. Usually ascospores are more or less longer and wider in $\mathrm{K}$ in comparison with measurements in water.

Representative specimens examined: Jammu \& Kashmir, Jammu district, Kud Dogra, 15 km before Patani Top, alt. 1,939 m, on rock, 21.11.2017, S. Nayaka, S. Joseph, J. Raval \& P. Randive LWG-17-030653, LWG-17-030626. - Madhya Pradesh, Dindori district, Khurkhuridadee, alt. 1,500 m, on rock, 07.07.2005, D. K. Upreti, S. Nayaka \& Satya, LWG05-005766. - Manipur, Ukhrul district, Lunghar village, alt. 1,853 m, on rock, 14.06.2017, K. K. Ingle LWG-17-031114. - Uttarakhand, Uttarakashi district, Govind Wildlife Sanctuary, on the way from Sankari to Taluka, alt. 2,145 m, on rocks, 13.05.2011, D. K. Upreti, S. Nayaka \& R. Bajpai LWG-11-016094.

\section{Ioplaca Poelt}

Type: Ioplaca sphalera Poelt

Two species of genus Ioplaca were hitherto known in the world, i.e. Ioplaca sphalera Poelt, (Poelt 1977) and I. pindarensis (Räsänen) Poelt et Hinter. (Poelt and Hinteregger 1993), which however were accepted as conspecific (Poelt and Hinteregger 1993). These two species have been known from India 
and are presented below. One more species of this genus was recently described from India (Kondratyuk et al. 2020a).

1 Thallus and apothecia grey, $\mathrm{K}$-, growing on both thalli of crustose lichens and on rock surface; ascospores narrowly ellipsoid, 13-19 × 8-9.5 $\mu \mathrm{m}$

\section{I. rinodinoides}

- Thallus yellowish orange, $\mathrm{K}+$ purple, growing on rock surface; ascospores various, usually very wide

2 Ascospores 8-18 $\times 11-22 \mu \mathrm{m}$

I. sphalera

- Ascospores 4-14 × 4-8 $\mu \mathrm{m}$

I. pindarensis

Ioplaca pindarensis (Räsänen) Poelt et Hinter., Bibl. Lichenol. 50: 235 (1993). - Thallus dark yellowish orange, rimose-areolate, overlying on dark undersurface, apothecia cryptolecanorine. Chemistry: Thallus, apothecial disc and epihymenium $\mathrm{K}+$ purple, $\mathrm{C}-, \mathrm{Pd}-, \mathrm{I}-$ : parietin in TLC. Ecology and distribution: The species grows on both calcareous and non-calcareous rocks in association with Aspicilia and Staurothele spp. in different localities of Arunachal Pradesh, Himachal Pradesh, Jammu \& Kashmir, Sikkim, Uttarakhand and West Bengal. Taxonomic notes: From our molecular data the genus Ioplaca includes at least three species, and probably both taxa (i.e. I. pindarensis and I. sphalera) are present in India. Furthermore, after our molecular data the genus Ioplaca includes at least one more species in the genus.

Representative specimens examined: Himachal Pradesh, Kangra district, Bir tea garden area, Billing Hills, alt. 2,000-2,500 m, 02.06.1994, D. K. Upreti, LWG-213612; Palampur, Bagh Nalla, alt. 1,400-2,000 m, 03.06.1994, D. K. Upreti, LWG-213645; Shimla district, Narkanda, 3-4 km towards Hatu Peak, alt. 2,800 m, on rock, 14.05.2002, S. Nayaka \& R. Srivastava, LWG-02-67155; Shimla district, Rohodu, Larote, Chanshal Pass, HSP-2, on rock, alt. 4,150 m, 25.08.2016, R. Bajpai, LWG-16-030316. - Jammu \& Kashmir, Anantnag district, Pahalgam, E side, alt. 2,450 m, on rock, 31.07.2005, M. Sheikh, LWG-05-034680. - Sikkim, East Sikkim, Tsango Lake, alt. 3,780 m, 06.09.2000, S. Chatterjee \& P. K. Divakar, LWG-2077122. - Uttarakhand, Almora district, Johar Ratpani, alt. 2,100 m, on rock, 01.10.1950, D. D. Awasthi, LWG-AWAS-813. Bageshwar district, Pindari Glacier; Loharkhet to Dhakuri, alt. 2,400 m, 18.05.1950, D. D. Awasthi \& A. M. Awasthi, LWG-AWAS-609, LWG-AWAS-619, LWG-AWAS-620; On the way to Khati from Dhakuri, on rock, 11.05.2007, Y. Joshi \& S. Joshi, LWG-07-010096, LWG-07-010095; Pithoragarh district, Munsiyari Khuliya Top, alt. 2,700-3,000 m, on rock, 16.11.2006, Y. Joshi \& R. Bajpai, LWG-06-006293, LWG-06-006232, LWG-06-006230, LWG-06-006228, LWG-06-006229.

Ioplaca rinodinoides S. Y. Kondr., K. K. Ingle, D. K. Upreti et S. Nayaka, Acta Bot. Hung. 62(1-2): 77 (2020). - This species is similar to Caloplaca diphyes (Nyl.) H. Olivier, but differs in having smaller apothecia and in having greyish thalline margin, in having larger and especially wider ascospores and in having much wider septum, as well as in having different host (Kondratyuk 
et al. 2020a). Chemistry: Thallus, apothecial disc and epihymenium $\mathrm{K}-$ or + dull yellow-brown, almost the same as in water, $\mathrm{C}-$, Pd-, I-: chemistry not studied further by TLC. Ecology and distribution: It grows on rock surface and/or crustose lichens as Upretia sp., Diploschistes sp., Ioplaca pindarensis, etc. in single locality of Nagaland.

Representative specimens examined: Nagaland, Kopima district, Vaisema to Dzukou valley, on rocks, growing together with Diploschistes sp. and Upretia sp. Lat.: $25^{\circ} 32^{\prime}$ 20.3" N, Long.: 94 05' 53.8" E; Alt.: 2,397 m a.s.l. Coll.: Ingle, K. K., 22.06.2017 (LWG-L 17031119 - holotype); the same locality (LWG-L 17-031118 - isotype).

Ioplaca sphalera Poelt, Khumbu Himal 6(3): 443 (1977). - The species is characterised by the subumbilicate areolate thallus, pale orange, $1 \mathrm{~mm}$ areoles; immersed cryptolecanorine apothecia, and 8-18 $\times 11-22 \mu \mathrm{m}$ ascospores (Poelt 1977). Chemistry: Thallus, apothecial disc and epihymenium K+ purple, KC-, C-, Pd-, I-: parietin present in TLC. Ecology and distribution: It occurs at high elevations in the Eastern Himalayas (Poelt 1977). Taxonomic notes: After the molecular studies Ioplaca sphalera is separated from I. pindarensis, earlier I. sphalera was considered under Ioplaca pindarensis.

Klauderuiella S. Y. Kondr. et J.-S. Hur

Type: Klauderuiella thallincola (Wedd.) S. Y. Kondr. et J.-S. Hur

About three species of the genus Klauderuiella are known in the world (Kondratyuk et al. 2017b), whereas two saxicolous species are reported from India.

1 Thallus white to pale yellow-orange, ascospores citriform, crystals absent

K. aurantia

- Thallus orange yellow to pale yellow, ascospores lemon-shaped slightly narrower and longer with more pointed apices, hyaline crystals are present

K. flavescens

Klauderuiella aurantia (Pers.) S. Y. Kondr. et J.-S. Hur, Acta Bot. Hung. 59(1-2): 121 (2017). - This species is characterised by a whitish variegated, centrally rugose-squamulose thallus, orange to yellowish apothecia, convex disc, ovoid ascospores, 12-16 × 6-8 $\mu \mathrm{m}$ (Awasthi 1991). Chemistry: Thallus, apothecial disc and epihymenium $\mathrm{K}+$ purple, $\mathrm{C}-$, $\mathrm{Pd}-$ : parietin present in TLC. Ecology and distribution: Saxicolous species from the Western Himalayas (Awasthi 1991).

Klauderuiella flavescens (Huds.) S. Y. Kondr. et J.-S. Hur, Acta Bot. Hung. 59(1-2): 121 (2017). - Thallus smooth, upper surface single coloured, 
orange to orange-yellow to pale yellow never zonate; central parts of thallus white due to absence of anthraquinone pigments, or the centre dies off with age; ascospores lemon-shaped, slightly narrower and longer with more pointed apices, 9-15 × 6-11 $\mu \mathrm{m}$. Chemistry: Thallus, apothecial disc and epihymenium $\mathrm{K}+$ purple, $\mathrm{C}-$, Pd-: parietin present in TLC. Ecology and distribution: Saxicolous species distributed between elevations of $c a$ 2,600-4,400 m at several localities of Jammu \& Kashmir and Himachal Pradesh.

Representative specimens examined: Jammu \& Kashmir, Srinagar district, Sankaracharya Hill, on rock, 03.11.1954, D. D. Awasthi, LWG-AWAS-2648. - Himachal Pradesh, Kinnaur district, Gara Glacier area, alt. 4,333 m, on limestone rock, D. N. Bhattacharya, LWG-AWAS.

Laundonia S. Y. Kondr., L. Lőkös et J.-S. Hur

Type: Laundonia flavovirescens (Wulfen) S. Y. Kondr., L. Lőkös et J.-S. Hur

Two species of Laundonia are known in the world (Kondratyuk et al. 2017b), one of which is found in India.

Laundonia flavovirescens (Wulfen) S. Y. Kondr., L. Lőkös et J.-S. Hur, Acta Bot. Hung. 59(1-2): 121 (2017). - This species is mainly characterised by greenish yellow, rimose to areolate thallus, with orange-brown convex apothecial disc surrounded by yellowish orange margin (Joshi 2008). Chemistry: Thallus, apothecial disc and epihymenium $\mathrm{K}+$ purple, $\mathrm{KC}-, \mathrm{C}-, \mathrm{Pd}-$ : parietin present in TLC. Ecology and distribution: The species is common on \pm calcareous rocks, rarely occurs on pure limestones, chiefly in upland areas in each phytogeographical region of Himachal Pradesh, Jammu \& Kashmir, Nagaland, Tamil Nadu and Uttarakhand.

Representative specimens examined: Himachal Pradesh, Chamba district, Brahmaur, Hadsar, Mani Mahesh, Doonch, alt. 1,600-2,100 m, on rock, 16.05.2001, D. K. Upreti \& S. Nayaka, LWG-01-75488. - Jammu \& Kashmir, Doda district, Kistwar, Sarthal, Forest area, on exposed rock, 03.11.2005, R. Rana, LWG-05-006068. - Tamil Nadu, Nilgiri hills, Love date, on stones, 01.12.1973, K. P. Singh, LWG-73-510, LWG-73-524. - Uttarakhand, Champawat district, Marodkhan on the way to Ghat, alt. 1,600 m, on rock, 27.11.2010, G. K. Mishra, LWG-10-015378.

Lazarenkoiopsis S. Y. Kondr., Lőkös et J.-S. Hur

Type: Lazarenkoiopsis ussuriensis (Oxner, S. Y. Kondr. et Elix) S. Y. Kondr., L. Lőkös et J.-S. Hur

The genus Lazarenkoiopsis is known in the world with a single species, occurring also in India (Kondratyuk et al. 2017b).

Lazarenkoiopsis ussuriensis (Oxner, S. Y. Kondr. et Elix) S. Y. Kondr., L. Lőkös et J.-S. Hur, Acta Bot. Hung. 59(1-2): 121 (2017). - This species is char- 
acterised by greenish-yellowish continuous or film-like crustose thallus and brighter yellow soralia with semiconvex to convex soredious mass; apothecia dull orange to dull brownish orange (Kondratyuk et al. 2011). Chemistry: Thallus, apothecial disc and epihymenium $\mathrm{K}+$ purple, $\mathrm{C}-, \mathrm{Pd}-$ : parietin present in TLC. Ecology and distribution: The species grows on Acacia nilotica bark between elevations of 640-2,200 $\mathrm{m}$ in the regions of Himachal Pradesh and Madhya Pradesh.

Representative specimens examined: Himachal Pradesh, Kullu district, Great Himalayan National Park, alt. ca 2,200 m, on bark, 06.04.2004, R. Srivastava, LWG-04-003319. - Madhya Pradesh, Dindori district, 13 km, before Kabir from Chauradader, alt. 640 m, on Acacia nilotica tree bark, 05.07.2005, D. K. Upreti, S. Nayaka \& Satya, LWG-05-005519/B.

\section{Leproplaca (Nyl.) Hue}

Type: Leproplaca xantholyta (Nyl.) Hue

In total six species of the genus Leproplaca are known from the world (Arup et al. 2013, Laundon 1974), three of them are known from India.

1 Thallus corticolous, brownish to orange, prothallus and apothecia absent

L. chrysodeta

- Thallus saxicolous, ochraceous yellow to orange, prothallus present or absent, apothecia present

2 Thallus with irregularly crowded, rounded to elongate lobules, rounded to diffused soralia with citrine-yellow soredia, apothecial disc, yelloworange, flat to subconvex, ascospores long to ellipsoid to almost globular, $10-12 \times 5-7 \mu \mathrm{m}$

L. obliterans

- Thallus verruculose and efflorescent, well-developed marginal lobes that are \pm paler at the tips, soredia yellow, apothecial disc orange, plane to convex, ascospores oblong, 13-18 $\times 5-6 \mu \mathrm{m}$

L. cirrochroa

Leproplaca chrysodeta (Vain.) J. R. Laundon ex Ahti, Graphis Scripta 27(1-2): 39 (2015). - This species is characterised by a brownish orange, entirely leprose thallus with a white cotton-like hypothallus and soredia forming consoredia, apothecia are not seen (Joshi 2008). Chemistry: Thallus K+ purple, $\mathrm{C}_{-}, \mathrm{KC}-, \mathrm{Pd}-, \mathrm{I}-$ : parietin present in TLC. Ecology and distribution: It grows on bark between altitudes of 600-2,100 m in Himachal Pradesh and West Bengal.

Representative specimens examined: Himachal Pradesh, Kullu district, Great Himalayan National Park, alt. 2,000-2,100 m, on bark, 03.11.2002, S. Nayaka \& R. Srivastava, LWG-02-001054. - West Bengal, Darjeeling district, Darjeeling-Pashok road, 3-6 miles 
from Darjeeling, alt. 1,950 m, on bark, 06.03.1967, D. D. Awasthi \& M. R. Agarwal, LWGLWU-67-128.

Leproplaca cirrochroa (Ach.) Arup, Frödén et Søchting, Nordic J. Bot. 31(1): 72 (2013). - It is characterised by centrally verruculose and efflorescent, yellow sorediate thallus, minutely laciniate, radiating, orange, margin rarely white pruinose, apothecial disc orange, ascospores oblong, 13-18 $\times 5-6 \mu \mathrm{m}$ (Upreti et al. 2005). Chemistry: Thallus $\mathrm{K}+$ purple, $\mathrm{C}-, \mathrm{KC}-, \mathrm{Pd}-$, I-: parietin present in TLC. Ecology and distribution: Saxicolous species growing at different altitudes of Jammu \& Kashmir and Madhya Pradesh (Upreti et al. 2005).

Leproplaca obliterans (Nyl.) Arup, Frödén et Søchting, Nordic J. Bot. 31(1): 72 (2013). - The species is characterised by non-radiate, ochraceous yellow to orange thallus with irregularly crowded, rounded to elongate lobules, rounded to diffuse soralia with citrine-yellow soredia (Joshi 2008). Chemistry: Thallus, soredia, apothecial disc and epihymenium $\mathrm{K}+$ purple, $\mathrm{KC}-, \mathrm{C}-$, $\mathrm{Pd}-$ : parietin present in TLC. Ecology and distribution: Saxicolous species growing on siliceous rocks in temperate regions of the Himalayas between elevations of 1,800-3,300 m in Jammu \& Kashmir, Rajasthan and Uttarakhand.

Representative specimens examined: Jammu \& Kashmir, Srinagar district, Harwan, Dachigam National Park, alt. 2,230 m, on unexposed rocks, 02.08.2005, M. Sheikh, LWG05-034681. - Uttarakhand, Bageshwar district, near Phurkia Dakbunglow, alt. 3,300 m, on rock, 10.06.1970, D. D. Awasthi, LWG-AWAS-7569, LWG-AWAS-7660; On the way to Dwali from Khati, on rock, 21.07.2007, Y. Joshi \& S. Joshi, LWG-07-010097.

\section{Massjukiella S. Y. Kondr., Fedorenko, S. Stenroos, Kärnefelt, Elix, J.-S. Hur et A. Thell}

Type: Massjukiella polycarpa (Hoffm.) S. Y. Kondr., Fedorenko, S. Stenroos, Kärnefelt, Elix, J.-S. Hur et A. Thell

The genus is represented by five species in the world (Fedorenko et al. 2012), of which two species are known from India.

1 Thallus fruticose to foliose, sorediate

M. candelaria

- Thallus foliose and without soredia

M. polycarpa

Massjukiella candelaria (L.) S. Y. Kondr., Fedorenko, S. Stenroos, Kärnefelt, Elix, J.-S. Hur et A. Thell, Bibl. Lichenol. 108: 60 (2012). - This species is clearly delimited from other sorediate species of the genus by having ellipsoid conidia and dimorphic thallus (Joshi 2008). Chemistry: Thallus K+ purple, KC-, C-, Pd-, I-: parietin (major), fallacinal, emodin, teloschistin and parietinic acid present in TLC. Ecology and distribution: It is restricted to areas from temperate to alpine in Himachal Pradesh, Jammu \& Kashmir and Uttarakhand. 
Representative specimens examined: Himachal Pradesh, Lahul Spiti district, Keylong, Gemaru, alt. 3,000-3,500 m, on cultivated Salix trees along the roadside, 14.09.2001, D. K. Upreti, LWG-01-26542. - Jammu \& Kashmir, Anantnag district, Baltal, alt. 2,700 m, on bark, 13.09.1982, A. Singh \& D. K. Upreti, LWG-11674; Budgam district, Yusmarg, near Nilnag road, alt. 2,200 m, on Cedrus deodara bark, 12.07.2004, M. Sheikh, LWG-04-004804.

Massjukiella polycarpa (Hoffm.) S. Y. Kondr., Fedorenko, S. Stenroos, Kärnefelt, Elix, J.-S. Hur et A. Thell, Bibl. Lichenol. 108: 60 (2012). - The species is mainly characterised by very small, richly apotheciate, \pm cushion like, yellowish thalli with short and narrow convex lobes. Chemistry: Upper surface $\mathrm{K}+$ purple, $\mathrm{C}-$, $\mathrm{Pd}-$, I-: parietin (major), fallacinal, emodin, teloschistin and parietinic acid present in TLC. Ecology and distribution: Corticolous species growing along with Athallia pyracea in temperate regions of Jammu \& Kashmir at an elevation of $1,650 \mathrm{~m}$.

Representative specimen examined: Jammu \& Kashmir, Srinagar district, Prang Garden, alt. 1,650 m, on bark, 10.06.1970, P. N. Mujoo, LWG-LWU-70.101.

\section{Mikhtomia S. Y. Kondr., Kärnefelt, Elix, A. Thell et J.-S. Hur}

Type: Mikhtomia gordejevii (Tomin) S. Y. Kondr., Kärnefelt, Elix, A. Thell, J. Kim, A. S. Kondratiuk et J.-S. Hur

Originally the genus Gyalolechia A. Massal. was represented by 56 species from the world (Arup et al. 2013). However, later it was shown that the genus Gyalolechia is polyphyletic (Kondratyuk et al. 2014a, 2017a). It was therefore split into several genera, i.e. Elenkiniana, Laundonia, Mikhtomia, Opeltia, Oxneriopsis, etc. Three species are known from the former Gyalolechia s. 1. in India, now belonging to the genera Mikhtomia, Opeltia and Oxneriopsis (Kondratyuk et al. 2014a, 2017a).

Mikhtomia gordejevii (Tomin) S. Y. Kondr., Kärnefelt, Elix, A. Thell, J. Kim, A. S. Kondratiuk et J.-S. Hur, Acta Bot. Hung. 56(1-2): 112 (2014). Thallus crustose, continuous to areolate, upper surface greenish grey to dark greenish or grey, or bright yellow or orange, cortical layer palisade paraplectenchymatous; apothecia biatorine, subhymenium and lower portion of hymenium richly inspersed with oil droplets; true exciple of Blastenia-type; ascospores polarilocular, asci 8-spored; conidia bacilliform to narrowly bacilliform. Chemistry: Thallus $\mathrm{K}-$ or $\mathrm{K}+$ purple, epihymenium $\mathrm{K}+$ purple, $\mathrm{C}-$, $\mathrm{Pd}-$ : parietin, anthraquinones of fragilin and parietin chemosyndromes, as well as gyrophoric acid in some species present in TLC. Ecology and distribution: It grows on bark between elevations of 1,500-3,065 $\mathrm{m}$ in Assam and Uttarakhand. Taxonomic notes: This species has been considered as a synonym of Mikhtomia flavorubescens for a long period. However, the latest revision of Eastern Asian material shows that $M$. gordejevii is a very distinct species both 
from morphological, and from chemical and molecular points of view (Kondratyuk et al. 2014a). It is recorded from India for the first time.

Representative specimens examined: Assam, Dima Hasao district, Dihangi, Thesiling House, near bus stand, alt. 273 m, on bark, 02.04.2017, G. K. Mishra, LWG-17-029675, LWG-17-029679. - Uttarakhand, Champawat district, near Guest House Champawat, on bark, 26.11.2010, G. K. Mishra, LWG-10-015377; Rudraprayag district, en route to Tungnath, alt. 3,065 m, on twig of Quercus, 16.05.2011, H. Rai, R. Khare \& P. Shukla, LWG-11-234356.

\section{Neobrownliella S. Y. Kondr., Elix, Kärnefelt et A. Thell}

Type: Neobrownliella brownlieae (S. Y. Kondr., Elix et Kärnefelt) S. Y. Kondr., Elix, Kärnefelt et A. Thell

The genus Neobrownliella included two species in the world (Kondratyuk et al. 2015d), two additional species are added to this genus in this paper (cf. new combinations below). Two species have been reported from India under various names (Awasthi 1965, Singh and Sinha 2010, and see synonyms below).

1 Thallus areolate to subeffigurate, cinnabarine coloured, ascospores 8-10 $\mu \mathrm{m}$ long

N. cinnabarina

- Thallus closely attached to substrate, but distinctly effigurate; brownish orange, ascospores to $14 \mu \mathrm{m}$ long

N. holochracea

Neobrownliella cinnabarina (Ach.) S. Y. Kondr., Upreti et A. Thell, comb. nova - MycoBank No.: MB 832437 - Basionym: Lecanora cinnabarina Ach., Lich. Univ., p. 402 (1810). इ Caloplaca cinnabarina (Ach.) Zahlbr., Nat. Pflanzenfam. 1(1), p. 228 (1908); Zahlbr., Cat. Lich. Univ. 7: 101 (1930). $\equiv$ Brownliella cinnabarina (Ach.) S. Y. Kondr., Kärnefelt, A. Thell, Elix, J. Kim, A. S. Kondr. et J.-S. Hur, Acta Bot. Hung. 55(3-4): 271 (2013). - The species is characterised by areolate to subeffigurate, cinnabarine coloured thallus with small, sunken to \pm sessile apothecia mostly obscuring the thallus (Joshi 2008). Chemistry: Thallus, apothecial disc and epihymenium $\mathrm{K}+$ purple, $\mathrm{C}-$, $\mathrm{Pd}-$, I-: parietin (major), emodin, teloschistin, fallacinal, xanthorin, parietinic acid present in TLC. Ecology and distribution: The species is common on granitic, calcareous rocks and sandstones in tropical and temperate regions in Himachal Pradesh, Karnataka, Madhya Pradesh, Meghalaya Orissa, Rajasthan, Tamil Nadu and Uttarakhand. Taxonomic notes: The Indian material of the Neobrownliella cinnabarina complex is not conspecific with $N$. cinnabarina s. str. as it is seen from the molecular data. All Indian specimens previously recorded as 'Caloplaca' cinnabarina therefore must be revised possibly as belonging to $N$. holochracea. The same status of 'Neobrownliella' cinnabarina itself is waiting for confirmation by molecular data, too. 
Representative specimens examined: Himachal Pradesh, Shimla-Tibet road (Kundara), alt. 2,700 m, 05.1949, H. C. Raghubir, LWG-AWAS-430; Kullu district, Great Himalayan National Park, Sairopa, alt. 1,440 m, on rock, 10.11.2002, S. Nayaka \& R. Srivastava, LWG02-001208. - Karnataka, Bangalore district, Bannergatta-Hazam-Kalu, alt. 980 m, 30.04.1979, D. D. Awasthi, D. K. Upreti \& U. C. Misra, LWG-LWU-79-212, LWG-LWU-79-213, LWGLWU-79-231. - Madhya Pradesh, Hoshangabad district, Pachmarhi Rang Mahal area, on rock, 26.11.2004, Y. Joshi, LWG-04-004542. - Orissa, Koraput district, Raisili village, 17.09.1993, V. Pande, LWG. - Rajasthan, Sirohi district, Mt Abu, Guru Shikher, alt. 1,680 m, 15.01.1973, A. Singh, LWG-101472. - Tamil Nadu, Chennai district, Pulmedu, Siruvani Hills, alt. 950 m, on rock, 14.11.1996, G. N. Hariharan, MSSRF-CS4. - Uttarakhand, Almora district, Kasardevi, alt. 1,800 m, 12.06.1956, D. D. Awasthi, LWG-AWAS-3464; Pithoragarh district, Gori Ganga Catchment, Jhali, alt. 2,300 m, 06.06.2000, V. Pant, LWG-20-67548.

Neobrownliella holochracea (Nyl.) S. Y. Kondr., Upreti et A. Thell, comb. nova (Figs 6, 7) - MycoBank No.: MB 832438 - Basionym: Lecanora holochracea Nyl. in Cromb., J. Linn. Soc., Bot. 15: 171 (1876). इCaloplaca holochracea (Nyl.) Zahlbr., Cat. Lich. Univ. 7: 144 (1930); D. D. Awasthi, Beih. Nova Hedwigia 17: 34 (1965). Type: India, Uttarakhand, Almora, Awasthi (holotype: H; isotype: LWG-Awasthi). - Syn.: Callopisma almorense Räsänen, Arch. Soc. Zool. Bot. Fenn. Vanamo 6(2): 83 (1952). झ Caloplaca almorensis (Räsänen) D. D. Awasthi, Beih. Nova Hedwigia 17: 33 (1965). - Thallus is very thin, as if "glued" to the substrate, areolate in the centre and distinctly effigurate at the margin, but flat in all parts, brownish orange, apothecia remaining immersed, disc often irregular in outline, 8.5-14 × 4.0-5.5 $\mu \mathrm{m}$ ascospores, septa $2-4 \mu \mathrm{m}$ wide. Chemistry: Thallus, apothecial disc and epihymenium $\mathrm{K}+$ purple, $\mathrm{C}-, \mathrm{Pd}-$,

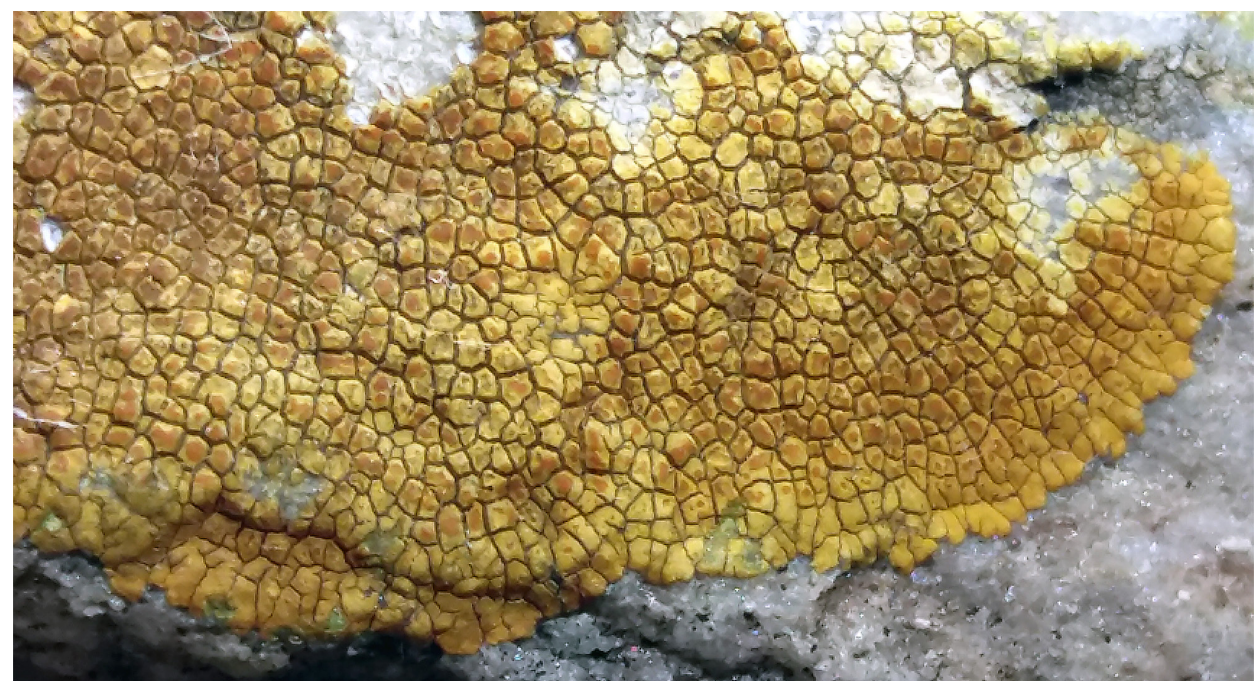

Fig. 6. Neobrownliella holochracea (holotype, LWG), habitat 
I-: parietin (major), emodin, teloschistin, fallacinal, xanthorin, parietinic acid present in TLC. Ecology and distribution: It occurs on plane to slightly sloping surface of quartz, tropical to warm temperate regions of Uttarakhand and West Bengal. Taxonomic note: The species is not conspecific with Neobrownliella cinnabarina according to molecular data.

Representative specimens examined: Uttarakhand, Almora district, Kasardevi, alt. 1,800 m, 12.06.1956, D. D. Awasthi, LWG-AWAS-3464; Bageshwar district, LoharkhetDhakuri (en route to Pindari glacier), alt. 2,400 m, 18.05.1950, D. D. Awasthi \& A. M. Awasthi, LWG-AWAS-620; Tehri Garhwal district, River Aglior valley, 13.10.1951, D. D. Awasthi, LWG-AWAS-855; Pithoragarh district, Berinag, near Pinus forest, alt. 5,000 ft, on stones, 26.09.1950, D. D. Awasthi, LWG-AWAS-804.

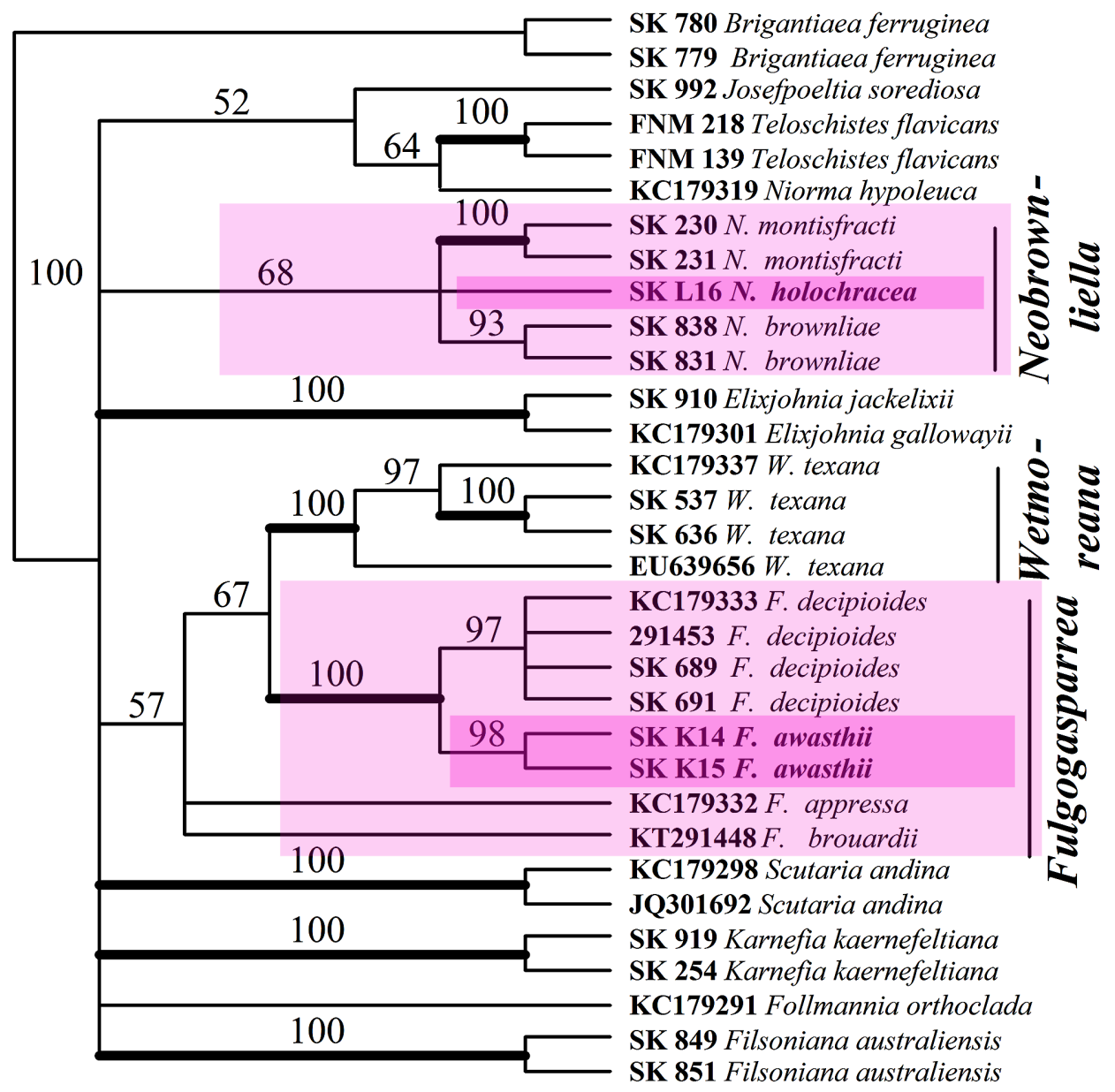

Fig. 7. Position of Neobrownliella holochracea and Fulgogasparrea awasthii in phylogenetic tree of the subfamily Teloschistoideae of the Teloschistaceae based on nrITS sequences 


\section{Olegblumia S. Y. Kondr., S.-O. Oh et J.-S. Hur}

Type: Olegblumia demissa (Flot.) S. Y. Kondr., L. Lőkös, J. Kim, A. S. Kondratiuk, S.-O. Oh et J.-S. Hur

Monotypic genus of the Caloplacoideae of the Teloschistaceae (Kondratyuk et al. 2015c). Its distribution encloses India.

Olegblumia demissa (Flot.) S. Y. Kondr., L. Lőkös, J. Kim, A. S. Kondratiuk, S.-O. Oh et J.-S. Hur, comb. nova - MycoBank No.: MB 832441 - Basionym: Placodium demissum Flot. ex Körb., Parerga lichenol. (Breslau) 1: 55 (1859). Lectotype UPS, Exs. Zw. L. 187 (designated by Arup and Grube, Lichenologist 31(5): 428 (1999). IImbricaria demissa Flot., Jber. Schles. Ges. Vaterl. Kultur 28: 133 (1850) (nom. inval., Art. 36.1b (Melbourne)). = Lecanora demissa Flot. ex Körb.) Zahlbr., Cat. Lich. Univ. 7: 509 (1931). = Caloplaca demissa (Flot.) Arup et Grube, Lichenologist 31: 428 (1999). = Olegblumia demissa (Flot.) S. Y. Kondr., L. Lőkös, J. Kim, A. S. Kondratiuk, S.-O. Oh et J.-S. Hur, Mycobiology 43(3): 200 (2015). (nom. inval., Art. 40.1 (Melbourne)). - Thallus rounded, rosette-like at first, then forming irregular aggregations, dull brownish yellow with \pm numerous darker orange apothecia in centre and widely gaping helmet-shaped soralia throughout with somewhat greenish yellow soredious mass. Chemistry: Thallus, apothecial disc and epihymenium $\mathrm{K}+$ purple, C-, Pd-: parietin (major), fallacinal (major), emodin, teloschistin (major) and parietinic acid present in TLC. Ecology and distribution: Saxicolous species found in Himachal Pradesh at an altitude of 3,632 m.

Representative specimen examined: Himachal Pradesh, Shimla district, Roholu, Larate, Chanshal pass, HSP-I, 31 $11^{\prime} 11.7^{\prime \prime} \mathrm{N}, 77^{\circ} 58^{\prime} 51.0^{\prime \prime}$ E, alt. 3,632 m, on rock, 24.08.2016, R. Bajpai, LWG-16-030321.

\section{Opeltia S. Y. Kondr. et L. Lőkös}

Type: Opeltia neobaltistanica S. Y. Kondr., L. Lőkös et J.-S. Hur

Originally the genus Opeltia S. Y. Kondr. et L. Lőkös represented three species from the world (Kondratyuk et al. 2017a). One more species of the genus Opeltia, i.e. O. flavorubescens, which has also been reported from India is recombined here and an additional new combination as a member of the genus Opeltia will be proposed in a forthcoming paper.

Opeltia flavorubescens (Huds.) S. Y. Kondr. et J.-S. Hur, comb. nova MycoBank No.: MB 832442 - Basionym: Lichen flavorubescens Huds., Fl. Angl., p. 443 (1762). 三 Caloplaca flavorubescens (Huds.) J. R. Laundon, Lichenologist 8: 147 (1976); D. D. Awasthi, Bibl. Lichenol. 40: 88 (1991). = Gyalolechia flavorubescens (Huds.) Søchting, Frödén et Arup, Nordic J. Bot. 31(1): 70 (2013). - Syn.: Lecanora aurantiacus Leight., Flora Scotica 2: 810 (1777). झ Caloplaca aurantiaca 
(Leight.) Th. Fr., Nova Acta Regiae Soc. Sci. Upsal., ser. 3, 3: 219 (1861); Zahlbr., Cat. Lich. Univ. 7: 69 (1930); D. D. Awasthi, Beih. Nova Hedwigia 17: 33 (1965). - This species is mainly characterised by the orange apothecia on a greenish yellow tinged continuous thallus (Joshi 2008). Chemistry: Thallus, apothecial disc and epihymenium $\mathrm{K}+$ purple, $\mathrm{KC}-, \mathrm{C}-, \mathrm{Pd}-$ : parietin present in TLC. Ecology and distribution: Widely distributed corticolous species growing along with parmelioid lichens and Lecanora, Lecidea, Xanthoria and members of lichen family Physciaceae and other Caloplaca species in tropical to temperate regions at different altitudes of Assam, Himachal Pradesh, Karnataka, Maharashtra, Manipur, Nagaland and Uttarakhand. Taxonomic notes: This species is positioned between the Mikhtomia and Laundonia branches based on molecular genetic analysis. However, its position is still not clarified.

Representative specimens examined: Assam, Dima Hasao district, Dihangi, Thesiling Hower, near bus stop, 52 km from New Haflong, alt. 273 m, on bark, 01.04.2017, G. K. Mishra, LWG-17-029690. - Himachal Pradesh, Bilaspur district, Namhol, Tepra, Bahadurpur, alt. 1,500-2,000 m, on tree trunk, 04.04.2003, D. K. Upreti, LWG-03-001339; Arki, Sakni forest, alt. 1,250 m, on bark, 04.12.2000, S. Nayaka, LWG-20-86731/B. - Maharashtra, Pune city, Thamini, alt. $600 \mathrm{~m}$, on Allophylus bark in scrub forest, 25.09.1999, S. Nayaka, LWG-99-86210.

\section{Oxneria S. Y. Kondr. et Kärnefelt}

Type: Oxneria alfredii (S. Y. Kondr. et Poelt) S. Y. Kondr. et Kärnefelt

Oxneria is represented with six species in the world (Fedorenko et al. 2009, 2012, Kondratyuk and Kärnefelt 2003), two of which are known from India.

1 Soralia of marginal crescent-shaped slit to widely gaping helmet-like O. huculica

- $\quad$ Soralia with soredious/blastidious mass on underside of the thallus O. ulophyllodes

Oxneria huculica S. Y. Kondr., Flora Lish. Ukr. (Kiev) 2(3): 435 (2010). - Thallus rounded, rosette-like at first, then forming irregular aggregations, dull brownish yellow with \pm numerous darker orange apothecia in centre and widely gaping helmet-shaped soralia throughout with somewhat greenish yellow soredious mass (Kondratyuk et al. 2010). Chemistry: Thallus, apothecial disc and epihymenium $\mathrm{K}+$ purple, $\mathrm{C}-$, $\mathrm{Pd}-$ : parietin (major), fallacinal (major), emodin, teloschistin (major) and parietinic acid present in TLC. Ecology and distribution: It grows on bark between altitudes of 1,662-3,500 $\mathrm{m}$ in Jammu \& Kashmir and Himachal Pradesh.

Representative specimens examined: Jammu \& Kashmir, Anantnag district, Achabal Mt, alt. 2,267 m, on bark of pine tree, 20.03.1970, P. N. Mujoo, LWG-LWU-70.24, LWGLWU-70.29; Srinagar district, Sankaracharya Hill, alt. 1,734 m, on bark of tree, 20.04.1970, P. 
N. Mujoo, LWG-LWU-70.63; Garden of the drug lab, alt. 1,667 m, on bark of tree, 30.10.1953, D. D. Awasthi, LWG-AWAS-2619. - Himachal Pradesh, Kinnaur district, Rikong Pev., alt. 2,700 m, on bark, 24.10.1978, A. Singh \& D. K. Upreti, LWG-L18278, Racksham-Chitkul, alt. 3,500 m, on Acer tree, 05.11.2003, D. K. Upreti, R. Srivastava \& Prakash, LWG-03-002758; Shimla district, Theog, $3 \mathrm{~km}$ towards Chaulla, on peach bark, 09.05.2002, S. Nayaka \& R. Srivastava, LWG-02-79034.

Oxneria ulophyllodes (Räsänen) S. Y. Kondr. et Kärnefelt, Ukr. bot. Zh. 60(4): 432 (2003). - The species is characterised by loosely adnate thallus producing marginal blastidia and numerous Oxneria-type rhizines projecting beyond the thallus (Joshi 2008). Chemistry: Upper surface $\mathrm{K}+$ purple, $\mathrm{C}-$, Pd-, I-: parietin, fallacinal, emodin, teloschistin and parietinic acid present in TLC. Ecology and distribution: A common and widespread species growing on bark or rocks in open to semi-open habitats, but also in \pm shady areas in temperate regions of Himachal Pradesh, Jammu \& Kashmir and Uttarakhand. Taxonomic note: Part of previous records of Oxneria ulophyllodes may belong to the newly described species Gallowayella awasthiana (Kondratyuk et al. 2018b).

Representative specimens examined: Himachal Pradesh, Shimla district, Rohodu, Larote, Chanshal Pass, HSP-2, on rock, alt. 4,150 m, 25.08.2016, R. Bajpai, LWG-16-030286. Parbati river valley, Bhaudag Thaj, alt. 3,300 m, on tree trunk, 25.06.1975, D. D. Awasthi \& K. Dange, LWG-LWU-75.357. - Jammu \& Kashmir, Anantnag district, Achbal Mountain, alt. 2,040-2,100 m, on Pinus bark, 20.03.1970, P. N. Mujoo, LWG-LWU-70.24, LWGLWU-70.29. - Uttarakhand, Chamoli district, Badrinath, alt. 3,150 m, on rocks, 28.09.1976, K. Dange, LWG-LWU-76.791; Uttarkashi district, Govind Wildlife Sanctuary, en route to Devkyara, Bencha, near Obra Devi temple, alt. 2,334 m, on rock, 16.10.2016, S. Nayaka, LWG-16-030808; Near bridge of Supin and Obra Ghat, alt. 2,065 m, on rock, 15.10.2016, S. Nayaka, LWG-16-030813.

\section{Oxneriopsis S. Y. Kondr., Upreti et J.-S. Hur}

Type: Oxneriopsis oxneri (S. Y. Kondr. et Søchting) S. Y. Kondr., Upreti et J.-S. Hur

The genus Oxneriopsis is represented by two species in the world (Kondratyuk et al. 2017a), only one of them is found in India.

Oxneriopsis bassiae (Ach.) S. Y. Kondr., Upreti et J.-S. Hur, comb. nova MycoBank No.: MB 832443 - Basionym: Lepraria bassiae Willd. ex Ach., Meth. Lich., p. 5 (1803). 三 Caloplaca bassiae (Willd. ex Ach.) Zahlbr., Cat. Lich. Univ. 7: 78 (1930); Wetmore, Bryologist 107(3): 289 (2004). E Gyalolechia bassiae (Ach.) Søchting, Frödén et Arup ex Ahti, Nordic J. Bot. 31(1): 70 (2013). - This species is characterised by a light yellow-orange to yellowish grey thallus surrounded by a black prothallus, orange coralloid isidia, biatorine apothecia and an inspersed hypothecium (Joshi 2008). Chemistry: Thallus, apothecial disc and epihymenium $\mathrm{K}+$ purple, $\mathrm{C}-$, $\mathrm{Pd}-$, I-: parietin, fragilin present in TLC. Ecology and distribution: It is a common species in India and widely distributed 
in tropical, subtropical and temperate regions of Andaman \& Nicobar Islands, Arunachal Pradesh, Assam, Bihar, Himachal Pradesh, Jammu \& Kashmir, Jharkhand, Madhya Pradesh, Orissa, Rajasthan, Sikkim, Tamil Nadu, Uttarakhand and Uttar Pradesh.

Representative specimens examined: Andaman Islands, Middle Andaman, Long Island, 27.03.1961, A. Singh, 89404 (LWG). - Assam, Dima Hasao district, Umrangso, from 8 miles towards Kopili, near Power Hose, alt. 652 m, on bark, 07.05.2017, D. K. Upreti, LWG-17-029688. North Cachar Hills district, Haflong, 01.08.2005, D. K. Upreti \& J. Rout, LWG-05-034682. - Bihar, Paschim Champaran district, Don Hills, SW Gadhi Campart, 20.02.1995, D. K. Upreti \& J. Tandon, LWG-213256. - Himachal Pradesh, Solan district, Nalagarh Baddi Dasora fort, alt. 500 m, 08.12.2000, S. Nayaka, LWG-2085649. - Jammu \& Kashmir, Jammu district, Jammu University Botanical Garden, alt. 305 m, 06.10.2004, M. A. Sheikh \& A. K. Raina, LWG-04-004571. - Jharkhand, Ranchi district, I. L. R. L. Namkum, 13.08.1997, S. Chatterjee, LWG-L 69766. - Madhya Pradesh, Anoopur district, Amarkantak, Mai ki Bagia, alt. 603 m, on Shorea robusta trunk, 23.03.2004, D. K. Upreti, S. Nayaka \& Satya, LWG-04-002434, LWG-04-002435, LWG-04-002439/C. - Orissa, Berhampur district, Taptapani, alt. 900 m, 03.1948, D. D. Awasthi, LWG-AWAS-392. - Rajasthan, Sirohi district, Mt Abu, alt. 1,200-1,350 m, 16.09.1985, D. D. Awasthi \& G. Awasthi, LWG-LWU-85.65, LWG-LWU-85.68. - Sikkim, South Sikkim, Namchi, $15 \mathrm{~km}$ towards Jorthang, alt. 1,000 m, 01.04.2001, D. K. Upreti \& S. Chatterjee, LWG-219562, LWG-219572. - Tamil Nadu, Kambam district, Meghamalai Wildlife Sanctuary, Mattuthulu, alt. 1,000 m, 21.03.1999, S. Nayaka, LWG-99-75930. - Uttarakhand, Dehra Dun district, Dholi Ghat, on the way to Lansdown, alt. 1,650 m, 12.10.1964, A. Singh, LWG-68007; Mussoorie/Chakrata Hills, on the way to Municipal garden, Joshi, LWG-LWU-75134. - Uttar Pradesh, Balrampur district, Rampur Dam, near water body, $27^{\circ} 51.514^{\prime} \mathrm{N}, 8^{\circ}$ 04.255' E, alt. $406 \mathrm{ft}$, on bark, 18.05.2018, K. K. Ingle, LWG-18-034605; Gandhela Nala, $27^{\circ} 49.533^{\prime} \mathrm{N}, 82^{\circ} 08.996^{\prime} \mathrm{E}$, alt. $531 \mathrm{ft}$, on bark, 20.05.2018, K. K. Ingle, LWG-18-034606; Sonpathri, $27^{\circ} 51.661^{\prime} \mathrm{N}, 8^{\circ} 09.284^{\prime} \mathrm{E}$, alt. $382 \mathrm{ft}$, on bark, 19.05.2018, K. K. Ingle, LWG-18-034607.

\section{Pachypeltis Søchting, Arup et Frödén}

Type: Pachypeltis invadens Søchting, Frödén et Arup in Arup et al.

Four species of the genus Pachypeltis were proposed (Arup et al. 2013), while combinations for three of them were proposed only on the basis of nrITS phylogeny results. A single species is found in India.

Pachypeltis intrudens (H. Magn.) Søchting, Frödén et Arup, Nordic J. Bot. 31(1): 48 (2013). - It is characterised by convex deeply reddish orange thalline areoles and concolorous immersed apothecia (Kondratyuk et al. 2004). Chemistry: Thallus, apothecial disc and epihymenium $\mathrm{K}+$ purple, $\mathrm{C}-, \mathrm{Pd}-$ : parietin present in TLC. Ecology and distribution: The species is known from mountainous areas of Middle Asian countries. It is new to India, growing on rocks at an altitude of 4,000 $\mathrm{m}$ in Himachal Pradesh.

Representative specimen examined: NW Himalayas, Kangra district, Mulh, alt. 14,000ft, 03.08.1952, O. A. Höeg, LWG-LWU-1600. 


\section{Polycauliona Hue}

Type: Polycauliona coralloides (Tuck.) Hue

According to the modern concept of Arup and colleagues (Arup et al. 2013), 43 species have been proposed to belong to the genus Polycauliona. However, later it was shown that the Polycauliona clade is rather polyphyletic (Kondratyuk et al. 2014b, 2017a). A single species of this genus is present in the Indian Himalayan region.

Polycauliona inconspecta (Arup) Arup, Frödén et Søchting, Nordic J. Bot. 31(1): 52 (2013). - It is characterised by the often abundant orange-yellow apothecia dominating over the thallus, which usually consists of yellow, convex, scattered to contiguous areoles. In addition, the apothecia are, in specimens with thallus, characteristically initiated in convex to subglobular areoles (Arup 1995a, b). Chemistry: Thallus and apothecia K+ purple, KC-, C-, Pd-, I-: parietin (major) and small amounts of emodin, teloschistin, parietinic acid, and maybe traces of fallacinal present in TLC. Ecology and distribution: The species is reported from temperate region of Maharashtra.

Representative specimens examined: Maharashtra, Amravati district, Gavilgad, 14.10.2007, U. V. Makhija \& B. C. Behra, AMH-07.126; Kolhapur district, Panhala, 09.09.1988, P. G. Patwardhan \& M. B. Nagarkar, AMH-88.101; Nashik district, Trimbakeshar Brahmagiri, 03.08.1974, M. B. Nagarkar \& A. V. Prabhu, AMH-74.247; Pune district, Durgwadi, 17.09.2004, U. V. Makhija, AMH-04.153.

\section{Pyrenodesmia A. Massal.}

Type: Pyrenodesmia chalybaea (Fr.) A. Massal.

The genus Pyrenodesmia s. str. is represented by six species in the world (Arup et al. 2013). Two species are known from India.*

1 Thallus blue-grey or greyish, areolate, fimbriate hypothallus, apothecia small, numerous, immersed in the thallus and without white pruinose thalline margin

P. chalybaea

- Thallus grey areolate, hypothallus is lacking, apothecia are large with often white pruinose thalline margin

P. variabilis

Pyrenodesmia chalybaea (Fr.) A. Massal., Atti Inst. Veneto Sci., Lett. ed Arti, Sér. 2, 3(3): 123 (1852). - This species is characterised by crustose, areolate to coarsely rimose-areolate greyish thallus with fimbriate black prothallus, numerous small apothecia, brownish red to blackish apothecial disc with concolorous proper margin, thalline margin \pm present, parathecium of oval to indistinct cells, algal cells absent in amphithecium, 6-14 × 3-6 $\mu \mathrm{m}$ ascospores, * See also four more species, under Caloplaca (i.e. C. aractina, C. diphyodes, C. haematites, and C. trascaspica). 
pycnidia numerous, ostiole brownish black to black (Joshi 2008). Chemistry: Thallus $\mathrm{K}+$ yellow, $\mathrm{KC}-$, $\mathrm{C}-$, $\mathrm{Pd}-$, I-; apothecial disc $\mathrm{K}+$ purple or $\mathrm{K}-$. Epihymenium $\mathrm{K}+$ faint purple: atranorin present in TLC. Ecology and distribution: It grows along with Squamulea subsoluta over boulders in the tropical regions of Madhya Pradesh and Tamil Nadu.

Representative specimens examined: Madhya Pradesh, Anuppur district, Amarkantak, $10 \mathrm{~km}$ before Kabir Chabutra (Attaria), alt. $510 \mathrm{~m}$, on quartz rocks, 22.03.2004, D. K. Upreti, S. Nayaka \& Satya, LWG-04-002372, LWG-04-002359/B; Hoshangabad district, Pachmarhi, on the way to a little fall, alt. 1,050 m, on rock, 24.01.1973, S. R. Singh, LWG-73-135. - Tamil Nadu, Chennai, Pulboli, LHS, alt. 1,030 m, on rock, 25.07.2000, G. Hariharan \& Balaji, MSSRF-CS12a.

Pyrenodesmia variabilis (Pers.) A. Massal., Atti Inst. Veneto Sci., Lett. ed Arti, Sér. 2, 3(3): 125 (1852). - This species is characterised by grey-areolate thallus, black apothecia with often white pruinose thalline margin, stout paraphyses and large ascospores (Joshi 2008). Chemistry: Thallus and apothecial disc $\mathrm{K}$ - to $\mathrm{K}+$ weak purple, $\mathrm{KC}-$, $\mathrm{C}-$, $\mathrm{Pd}-$; epihymenium $\mathrm{K}+$ weakly purple, I+ blue: no lichen substance is present in TLC. Ecology and distribution: The species grows over calcareous rocks in alpine regions of Himachal Pradesh, Jammu \& Kashmir and Uttarakhand.

Representative specimens examined: Himachal Pradesh, Kangra district, Khybar, on rock, 10.08.1952, O. A. Höeg, LWG-AWAS-1661, LWG-AWAS-1669; Lahul Spiti district, Spiti valley, Lithang, alt. 3,400 m, on exposed rocks, 05.08.2002, D. K. Upreti \& P. K. Divakar, LWG-02-000116/B. - Jammu \& Kashmir, Leh district, Ganglas area, alt. 4,000 m, on exposed rocks, 08.08.2003, D. K. Upreti \& S. Chatterjee, LWG-03-001814/B. - Uttarakhand, Chamoli district, Malari, on rocks, 24.09.2006, S. Rawat, LWG-06-006776.

\section{Rufoplaca Arup, Søchting et Frödén}

Type: Rufoplaca subpallida (H. Magn.) Arup, Søchting et Frödén

A total of seven species of the genus Rufoplaca has been reported in the world at first (Arup et al. 2013) and three more species were described from Eastern Asia (Kondratyuk et al. 2017b, 2018b, 2019a), two of them are known from India.

1 Thallus greyish to black, minutely areolate, apothecial disc dark ferrugineus

R. scotoplaca

- Thallus indistinct whitish grey, apothecial disc rust red

R. arenaria

Rufoplaca arenaria (Pers.) Arup, Søchting et Frödén, Nordic J. Bot. 31(1): 74 (2013). - This species is mainly characterised by indistinct whitish grey thallus, numerous apothecia with ellipsoid to sickle shaped ascospores having narrow isthmus (Joshi 2008). Chemistry: Thallus $\mathrm{K}-, \mathrm{KC}-, \mathrm{C}-$, $\mathrm{Pd}-$; apothecial disc and epihymenium K+ purple: parietin present in TLC. Ecology and distribution: Saxicolous species growing on exposed rocks in association 
with Acarospora, Aspicilia, Buellia, Porpidia and Rhizocarpon between elevations of 2,750-4,700 m in Himachal Pradesh, Jammu \& Kashmir and Uttarakhand.

Representative specimens examined: Himachal Pradesh, Lahul Spiti district, Baralacha La Pass, top area, alt. 4,700 m, on exposed rocks, 04.08.2003, D. K. Upreti \& S. Chatterjee, LWG-03-001772. - Jammu \& Kashmir, Baramullah district, Gulmarg, on the way to Khalinmarg, alt. 2,750 m, on rocks, 23.08.2005, M. Sheikh, LWG-05-034682; Leh district, Ladak, Khardungla Pass area, alt. 4,700 m, on exposed rocks, 08.08.2003, D. K. Upreti \& S. Chatterjee, LWG-03-001810. - Uttarakhand, Chamoli district, before Malari, on the way to Niti, alt. 3,086 m, on exposed rocks, 19.08.2007, D. K. Upreti \& S. Nayaka, LWG-07-011223.

Rufoplaca scotoplaca (Nyl.) Arup, Søchting et Frödén, Nordic J. Bot. 31(1): 74 (2013). - The species is characterised by the minutely areolate greyish black thallus and ferrugineus to ferrugineus brown apothecial disc, $0.2-0.4$ $\mathrm{mm}$ diam. apothecia, thin, persistent, thalline margin, concolorous with disc, 10-12 $\times 7-9 \mu \mathrm{m}$ ascospores, and $4.5 \mu \mathrm{m}$ thick septum (Singh 1981). Chemistry: Thallus $\mathrm{K}-, \mathrm{KC}-, \mathrm{C}-, \mathrm{Pd}-$; apothecial disc and epihymenium $\mathrm{K}+$ purple: parietin present in TLC. Ecology and distribution: The species is reported from Manipur and Sikkim (Singh 1981).

\section{Rusavskia S. Y. Kondr. et Kärnefelt}

Type: Rusavskia elegans (Link) S. Y. Kondr. et Kärnefelt

A total of 19 species of the genus Rusavskia are known in the world (Kondratyuk and Kärnefelt 2003, Kondratyuk et al. 2017a, 2020a) and six species are known from India.

1 Thallus with soredia or isidia

- Thallus without soredia or isidia

2 Thallus sorediate, soredia granular, apothecia rare

$R$. sorediata

- Thallus isidiate, isidia cylindrical to globose, apothecia are present or absent

3 Thallus reddish orange, isidia granular to prolonged

R. granulifera

- Thallus greenish to yellowish or different colour, isidia finger-like or lobule-like

4 Thallus saxicolous, lobes shorter and narrower, isidia funnel-like, rhizines simple if present, apothecia present

R. indica

- Thallus corticolous, distinctly widened towards the peripheral portion, finger- or lobule-like isidia and uplifted gall-like aggregations, holdfastlike rhizines, and apothecia absent

R. upretii 
5 Thallus reddish orange, pseudocyphellae absent, apothecia usually present

R. elegans

- $\quad$ Thallus dull yellowish orange, pseudocyphellae present, apothecia rarely observed

R. indochinensis

Rusavskia elegans (Link) S. Y. Kondr. et Kärnefelt, Ukr. Bot. Zh. 60(4): 434 (2003). - It is mainly characterised by reddish orange, effigurate thallus attached to the substratum by means of small hapters and presence of lower cortex (Joshi 2008). Chemistry: Thallus $\mathrm{K}+$ purple, $\mathrm{KC}-, \mathrm{C}-, \mathrm{Pd}-, \mathrm{I}-$ : parietin (major), fallacinal, emodin, teloschistin and parietinic acid present in TLC. Ecology and distribution: It occurs in temperate and alpine regions of Himachal Pradesh, Jammu \& Kashmir, Sikkim and Uttarakhand.

Representative specimens examined: Himachal Pradesh, Kangra district, one mile S of Sangam, on boulders, 06.08.1952, O. A. Höeg, LWG-AWAS-1625; Shimla district, Rohodu, Larote, Chanshal Pass, HSP-2, alt. 3,632 m, on rock, 24.08.2016, R. Bajpai, LWG-16-030318. Jammu \& Kashmir, Anantnag district, Pahalgam, on the way to Chandanwari, alt. ca 2,700 m, on boulders, 29.06.1977, K. Dange, LWG-LWU-77.275, LWG-LWU-77.296, LWG-LWU-77.309, LWG-LWU-77.313, LWG-LWU-77.324, LWG-LWU-77.333; Khardungla Pass area, alt. 4,7005,000 m, on rocks, 08.08.2003, D. K. Upreti \& S. Chatterjee, LWG-03-001800, LWG-03-001808. - Uttarakhand, Bageshwar district, Pindari Glacier; Phuria to Mirtoli, alt. 3,450 m, on stones and rocks, 11.06.1970, D. D. Awasthi, LWG-AWAS-7734; Phurkia to Zero Point, alt. 3,2103,660 m, on rock, 14.05.2007, S. Joshi \& Y. Joshi, LWG-07-008901, LWG-07-008926; Pithoragarh district, Beiju Milam Glacier, alt. 3,420 m, on rock, 20.10.2007, S. Joshi, LWG-07-010541.

Rusavskia granulifera (Giralt, Nimis et Poelt) S. Y. Kondr., Ukr. Bot. Zh. 60(4): 434 (2003). - The species is mainly characterised by granular to somewhat prolonged isidiate reddish orange foliose thallus having numerous apothecia (Joshi 2008). Chemistry: Upper surface K+ purple, KC-, C-, Pd-, I-: parietin (major), fallacinal, emodin, teloschistin and parietinic acid present in TLC. Ecology and distribution: Saxicolous species growing between altitudes of 3,700-4,000 $\mathrm{m}$ in Uttarakhand.

Representative specimens examined: Uttarakhand, Uttarkashi district, Govind Wildlife Sanctuary, en route to Devkyara, $3 \mathrm{~km}$ from Jaire, alt. 3,733 m, on rock, 17.10.2016, S. Nayaka, LWG-16-030807; Devkyara, grassland, alt. 4,040 m, on rock, 18.10.2016, S. Nayaka, LWG-16-030812.

Rusavskia indica S. Y. Kondr. et Upreti, Acta Bot. Hung. 59(1-2): 197 (2017). - It is characterised by narrower thalline lobes, narrower marginal zone without isidia or soredia, isidiate/schizidiate, which are very unstable in early stages and can be easily damaged/broken, and leaving characteristic spots (funnel-like deepening in cortical layer), wider ascospores, septum, and in growing on different substrate (Kondratyuk et al. 2017a). Chemistry: Thallus and epihymenium $\mathrm{K}+$ crimson purple, sometime blackish purple in places, K-, C-, Pd-: chemistry was not studied further by TLC. Ecology and 
distribution: The species grows on bark of coniferous trees, as well as on rock in Andaman Islands, Jammu \& Kashmir, Himachal Pradesh and Uttarakhand. Representative specimens examined: Andaman Islands, Middle Andaman, Long Island, sea level, on rock, 27.03.1961, A. Singh, LWG-89405. - Himachal Pradesh, Lahul Spiti district, Spiti Valley, 7 km before Pagma, from Kaza side, on rock, alt. 3,700 m, 05.08.2002, D. K. Upreti \& P. K. Divakar, LWG-02-00104. - Jammu \& Kashmir: Anantnag district, Baltal, on rock, alt. 2,700 m, 29.08.1982, A. Singh, LWG-13917; Pahalgam, on the way to Chandanwari, on rock, alt. 2,700 m, 29.06.1977, K. Dange, LWG-LWU-77.324, LWG-LWU-77.333, LWG-LWU-77.313, LWG-LWU-77.396, LWG-LWU-77.275. - Uttarakhand, Bageshwar district, near Pindari Glacier, Mirtoli to ridge of moraine, on rock, alt. 4,000 m, 11.06.1970, D. D. Awasthi, LWG-AWAS-7704; Chamoli district, Badrinath, Mana village, on rocks, 21.06.2005, V. Shukla \& Y. Joshi, LWG-05-005371.

Rusavskia indochinensis S. Y. Kondr., G. K. Mishra, S. Nayaka et D. K. Upreti, Acta Bot. Hung. 62(1-2): 94 (2020). - This species is similar to Zeroviella species (i.e. Z. digitata, Z. domogledensis and Z. papillifera), especially after having dull yellow-orange thallus with pseudocyphellae, but differs in the lack of isidia-like formations (Kondratyuk et al. 2020a). In having somewhat palmate terminal portions of the thalline lobes (sometimes they are divided in terminal portions into 5-7 sublobules in R. indochinensis) it is similar to Zeroviella digitata (S. Y. Kondr.) S. Y. Kondr. et Hur, endemic species of southeastern Europe (Ukrainian Crimea), but differs in having much larger measurements of lobes and secondary sublobules, as well as in the lack of isidia-like formations (Kondratyuk et al. 2004, 2020a). Chemistry: Thallus and epihymenium K+ crimson purple, C-, Pd-: chemistry was not studied further by TLC. Ecology and distribution: It grows on siliceous rock outcrops. It is known from scattered and distant localities in southern part of Asia (India and China) so far.

Representative specimens examined: Himachal Pradesh, Kullu district, Kasol village, on the way to Manikaran, on a rock with mosses. Lat.: $32^{\circ} 0.795^{\prime} \mathrm{N}$; Long.: $77^{\circ} 19.319^{\prime}$ E; Alt.: 1,777 m a.s.1. Coll.: Bajpai, R., 01.06.2013 (LWG-13-019788, paratype). - Uttarakhand, Chamoli district, $17 \mathrm{~km}$ before Malari, on the way to Niti, alt. 2,462 m, on exposed rock. Coll.: Upreti, D. K. \& Nayaka, S., 19.08.2007 (LWG-07-011210, holotype).

Rusavskia sorediata (Vain.) S. Y. Kondr. et Kärnefelt, Ukr. Bot. Zh. 60(4): 434 (2003). - The species is mainly characterised by horizontal, foliose thallus having laminal isidia breaking into soredia (Joshi 2008). Chemistry: Upper surface $\mathrm{K}+$ purple, $\mathrm{KC}-, \mathrm{C}-$, $\mathrm{Pd}-$, I-: parietin (major), fallacinal, emodin, teloschistin and parietinic acid present in TLC. Ecology and distribution: Saxicolous species growing in temperate and alpine regions of Andaman Islands, Himachal Pradesh, Jammu \& Kashmir and Uttarakhand.

Representative specimens examined: Himachal Pradesh, Kinnaur district, Recong Peo, in and around Kalpa, alt. 2,950 m, on rock, 03.11.2003, D. K. Upreti, R. Srivastava \& Prakash, LWG-03-002642. - Jammu \& Kashmir, Anantnag district, Pahalgam, Baltal, alt. 2,700 m, on rock, 29.08.1982, A. Singh \& D. K. Upreti, LWG-13917. - Uttarakhand, Bageshwar district, Martoli plain, near Pindari, alt. 3,750 m, on rock, 27.05.1972, A. Singh, LWG- 
91982; Chamoli district, Bhimpul, on rock, 21.06.2005, V. Shukla \& Y. Joshi, LWG-05-004996, LWG-05-005244, LWG-05-005246, LWG-05-005346.

Rusavskia upretii S. Y. Kondr., G. K. Mishra et S. Nayaka, Acta Bot. Hung. 59(1-2): 202 (2017). - The species is characterised by dispersed, scattered, and lax thalline lobes attached to the substrate, distinctly widened towards the peripheral portion, not forming regular rosette-like thalli, fingerlike or lobule-like isidia forming spherical, uplifted gall-like aggregations, as well as rhizine-like holdfast (Kondratyuk et al. 2017a). Chemistry: Not studied. Ecology and distribution: The species grows on siliceous rocks in Uttarakhand at an altitude of 3,300 m.

Representative specimens examined: Uttarakhand, Chamoli district, $10 \mathrm{~km}$ before Gamsali, on the way to Niti, alt. 3,300 m, on rocks under Cedrus deodara forest, 20.08.2007, D. K. Upreti \& S. Nayaka, LWG-07-011218, LWG-07-011218/B.

Scythioria S. Y. Kondr., Kärnefelt, Elix, A. Thell et J.-S. Hur Type: Scythioria phlogina (Ach.) S. Y. Kondr., Kärnefelt, Elix, Thell et J.-S. Hur

Three species of the genus are known in the world (Kondratyuk et al. $2014 b$ ), one of them is reported from India.

Scythioria phlogina (Ach.) S. Y. Kondr., Kärnefelt, Elix, A. Thell et J.-S. Hur, Acta Bot. Hung. 56(1-2): 164 (2014). - The species is characterised by a yellow to yellowish orange areolate thallus, convex areoles, round to irregular soredia arising marginally spreading over the surface (Joshi 2008). Chemistry: Thallus and soredia $\mathrm{K}+$ purple, $\mathrm{KC}-, \mathrm{C}-$, $\mathrm{Pd}-$ : parietin present in TLC. Ecology and distribution: Corticolous species growing on bark of Cedrus deodara and Acacia nilotica between elevations of 1,300-1,750 m in Madhya Pradesh and Uttarakhand.

Representative specimens examined: Madhya Pradesh, Dindori district, $7 \mathrm{~km}$ before Karangia from Gorakhpur, alt. 1,300 m, on Acacia nilotica tree trunk, 05.07.2005, D. K. Upreti, S. Nayaka \& Satya, LWG-05-005519/B. - Uttarakhand, Chamoli district, Juma area, alt. 3,200 m, on wood, 24.09.2006, S. Rawat, LWG-06-006241; Pauri district, Pauri, Kandoliya, on bark of Cedrus deodara, 19.06.2005, V. Shukla \& Y. Joshi, LWG-05-005137.

\section{Squamulea Arup, Søchting et Frödén}

Type: Squamulea subsoluta (Nyl.) Arup, Søchting et Frödén

Seven species of the cosmopolitan genus Squamulea are known in the world (Arup et al. 2013), three of them have been reported from India, as well as one species described here as new. 
1 Prothallus present, black, ascospores narrowly ellipsoid, 7-15 $\times 4-7 \mu \mathrm{m}$

S. subsoluta

- Prothallus absent, ascospores ellipsoid, 8-14 × 4.8-7 $\mu \mathrm{m}$

2 Thallus areolate to subsquamulose, with short marginal lobes, cortex without necral layer

S. parviloba

- Thallus squamulose, ascending, often subimbricate, cortex with necral layer

3 Ascospores wide, 5.5-7 $\mu \mathrm{m}$ wide

S. squamosa

- Ascospores narrower, 4.5-6 $\mu \mathrm{m}$ wide

S. uttarkashiana

Squamulea parviloba (Wetmore) Arup, Søchting et Frödén, Nordic J. Bot. 31(1): 56 (2013). - This species is characterised by areolate to subsquamulose thallus with short marginal lobes and margins of areoles having numerous short lobules. Chemistry: Thallus, apothecial disc and epihymenium K+ purple, $\mathrm{C}-, \mathrm{Pd}-$ : parietin present in TLC. Ecology and distribution: It grows along with Rinodina and Endocarpon spp. between elevations of 1,305-2,800 m in Himachal Pradesh, Tamil Nadu and Uttarakhand.

Representative specimens examined: Himachal Pradesh, Shimla district, Narkanda, 3-4 km towards Hatu Peak, alt. 2,800 m, on rock, 14.05.2002, S. Nayaka \& R. Srivastava, LWG-02-67173. - Tamil Nadu, Palni Hills, Hill view, below Perumal Malai, alt. 1,305 m, on stones, 05.01.1970, D. D. Awasthi \& K. P. Singh, LWG-LWU-70-443. - Uttarakhand, Pithoragarh district, Gori Ganga Catchment, East Ghandhura, alt. 1,600-2,000 m, on rock, 03.10.2002, V. Pant, LWG-02-000872.

Squamulea squamosa (B. de Lesd.) Arup, Søchting et Frödén, Nordic J. Bot. 31(1): 56 (2013). - This species is characterised by yellow-orange, squamulose thallus with uplifted margins, occasionally with $0.2-0.6 \mathrm{~mm}$ wide lobes, cortex with necral layer, apothecia with persistent, smooth to \pm crenulate thalline margin concolorous with thallus, hypothecium and parathecium paraplectenchymatous, paraphyses with $2-3$ slightly swollen tip cells, ascospores 8.0-12.0 × 4.8-6.0 $\mu \mathrm{m}$, isthmus 2.8-3.0 $\mu \mathrm{m}$ (Joshi 2008). Chemistry: Thallus $\mathrm{K}+$ purple, $\mathrm{KC}-, \mathrm{C}-, \mathrm{Pd}-$ : apothecial disc and epihymenium $\mathrm{K}+$ purple: parietin present in TLC. Ecology and distribution: The species grows on siliceous rocks at an altitude of 3,000 $\mathrm{m}$ in Uttarakhand.

Representative specimens examined: Uttarakhand, Uttarkashi district, Govind Wildlife Sanctuary, en route to Devkyara, towards Bencha, alt. 2,042 m, on rock, 15.10.2016, S. Nayaka, LWG-16-030810.

Squamulea subsoluta (Nyl.) Arup, Søchting et Frödén, Nordic J. Bot. 31(1): 56 (2013). - The species is characterised by yellowish orange, areolate to subsquamulose or squamulose thallus with slightly uplifted margins and the paraplectenchymatous hypothecium and medulla (Joshi 2008). Chemistry: Thallus, 
apothecial disc and epihymenium $\mathrm{K}+$ purple, $\mathrm{C}-\mathrm{Pd}$-: parietin present in TLC. Ecology and distribution: It is one of the most common species growing over non-calcareous rocks, but sometimes it grows on calcareous rocks and rarely on barks in Himachal Pradesh, Madhya Pradesh, Tamil Nadu and Uttarakhand.

Representative specimens examined: Himachal Pradesh, Shimla district, Rohodu, Larote, Chanshal Pass, HSP-2, alt. 3,632 m, on rock, 24.08.2016, R. Bajpai, LWG-16-030321. - Madhya Pradesh, Anoopur district, Amarkantak, $3 \mathrm{~km}$ from Jwaleshwar, alt. $603 \mathrm{~m}$, on rock, 23.03.2004, D. K. Upreti, S. Nayaka \& Satya, LWG-04-002840, LWG-04-002851. - Tamil Nadu, Palni Hills, Oothu area, alt. 1,050-1,200 m, 04.01.1970, D. D. Awasthi \& K. P. Singh, LWG-LWU-70.361; Chennai, Kevalankadu, Thonimalai, alt. 1,000 m, on rock, 18.02.2002, G. N. Hariharan \& P. Balaji, MSSRF-TH37. - Uttarakhand, Almora district, Almora, Thapalia village, G. B. Tewaris house, alt. 1,500 m, on lime plaster, 03.05.1988, D. K. Upreti, LWGL18397; Chamoli district, Joshimath, Jogifall, on rock, 22.06.2005, V. Shukla \& Y. Joshi, LWG-05-005266.

\section{Squamulea uttarkashiana S. Y. Kondr., Upreti, Nayaka \& A. Thell, spec. nova}

$$
\text { (Figs 4, 5, 8) }
$$

MycoBank No.: MB 832444

Similar to Huriella loekoesiana, but differs in having narrower ascospore septum as well as in forming separate branch within the Squamulea clade of the subfamily Xanthorioideae after nrITS1/ITS2 sequences (Fig. 4).

Type: India, Uttarakhand, Uttarkashi district, Govind Wildlife Sanctuary, en route to Devkyara, 5 km from Obradevi Temple, alt. 2,768 m, 16.10.2016, S. Nayaka, LWG-16-020398 (holotype); the same locality, LWG-16-020397, LWG-16-020399 (isotypes).

Thallus from (5-)7-12 $\mathrm{mm}$ across to much larger aggregations to several $\mathrm{cm}$ across, crustose, areolate-squamulose, dull yellowish brown or dull brownish orange-yellow, mostly numerous apothecia, very indistinctly concolorous with thallus. Areoles from very small, $0.1-0.2 \mathrm{~mm}$ across and very thin to $0.5-1.0(-1.5) \mathrm{mm}$ across, often somewhat flattened and elongated along the thallus margin, giving an impression of a lobate thallus, to $0.7-1.0 \mathrm{~mm}$ long with somewhat lighter, dull yellowish edge; areole edges mostly closely attached to the substrate (not ascending!). In section thalline areoles to (100-) 170-250 $\mu \mathrm{m}$ thick, cortical layer paraplectenchymatous to $30-40(-70) \mu \mathrm{m}$ thick, cell lumina 7-12(-17) $\mu \mathrm{m}$ long/across slightly vertically elongated; medulla throughout paraplectenchymatous; algal cells $12-19(-21) \mu \mathrm{m}$ diam./ across, trebouxioid. Apothecia (0.15-)0.2-0.4(-0.6) $\mathrm{mm}$ diam., and to $0.3 \mathrm{~mm}$ thick in section, mostly very indistinct, $1-2$ per areole, very small and concolorous with thallus, dull yellowish brown or brownish yellow, more or less immersed at 
first, biatorine or lecanorine to zeorine within the same thallus; thalline margin to $0.1 \mathrm{~mm}$ wide if apothecia lecanorine, dull yellowish brown or brownish yellow; own margin to $0.02-0.04 \mathrm{~mm}$ wide slightly lighter dull yellowish orange if apothecia zeorine, and disc somewhat darker, brownish orange to pale brown, sometimes to dull brownish yellow or somewhat dull pink brownish, plane and usually distinctly uplifted above the level of thalline areoles; in section lecanorine, thalline exciple to $120-150 \mu \mathrm{m}$ wide, especially in the lower lateral portion, cortical layer to $20-30 \mu \mathrm{m}$ thick well developed, paraplectenchymatous, cell lumina angular to $8-10 \mu \mathrm{m}$ diam./across; true exciple to $70-80$ $\mu \mathrm{m}$ thick in the uppermost lateral portion, to $15-20 \mu \mathrm{m}$ thick in lower lateral portion, of textura globosa/paraplectenchymatous with rounded cell lumina, in basal portion to $20-30(-40) \mu \mathrm{m}$ thick, paraplectenchymatous with rounded cell lumina to 10-13 $\mu \mathrm{m}$ diam./across; hymenium 60-70 $\mu \mathrm{m}$ high, epihymenium to $5-10 \mu \mathrm{m}$ thick, paraphyses slightly swollen towards the tips to 3.5-4.5 $\mu \mathrm{m}$ diam.; subhymenium to 100-150 $\mu$ m thick, hyaline, without oil droplets; algal zone to $100 \mu \mathrm{m}$ thick in lateral portion, algal cells to (8-)12-21 $\mu \mathrm{m}$ diam.; asci 8-spored, to $52 \times 17 \mu \mathrm{m}$, often with ascospores of various size within the same ascus (better seen in K); ascospores widely ellipsoid, sometimes one cell
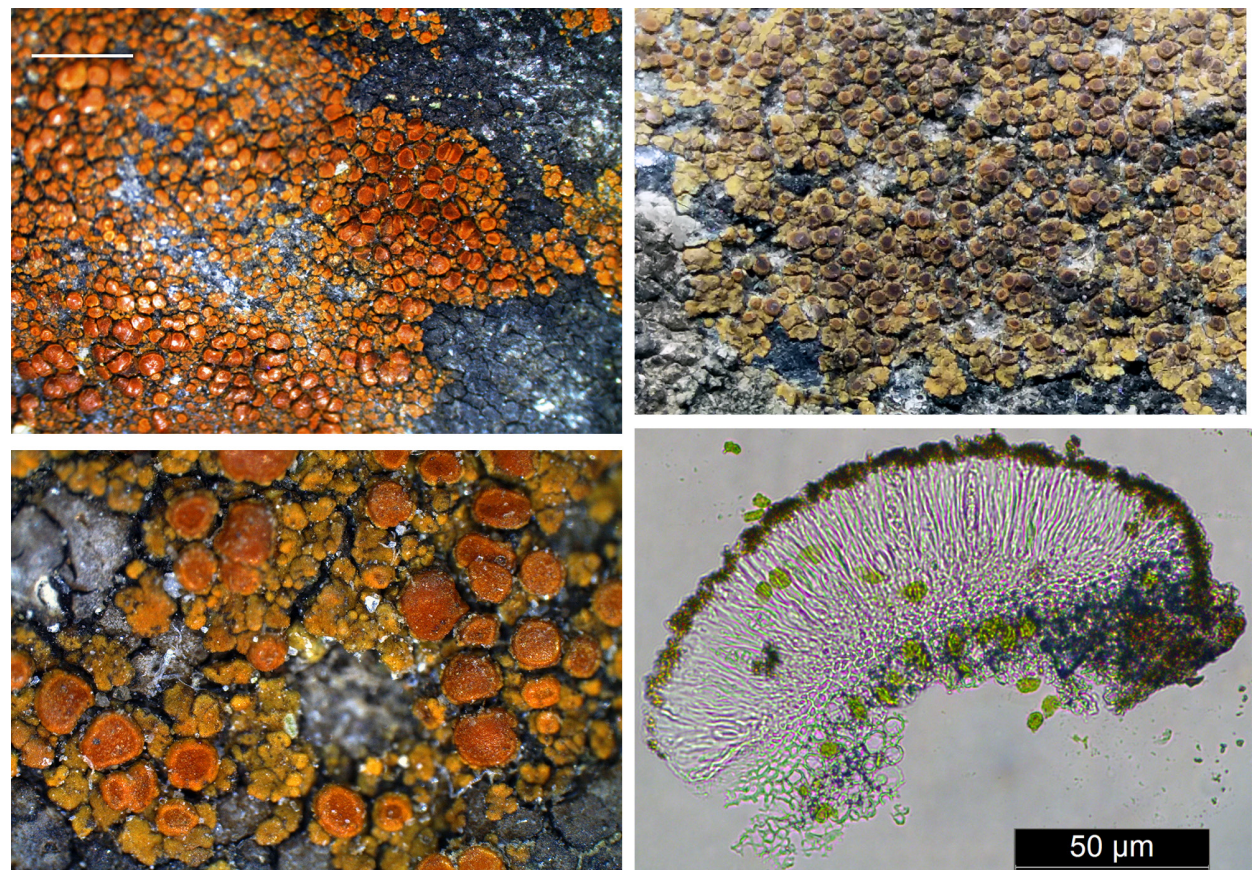

Fig. 8. Squamulea uttarkashiana (holotype, LWG), enlarged portion with apothecia (lower left), section of apothecium. Scale: $50 \mu \mathrm{m}$ 
is larger than the other, $(8-) 10-10.5 \times 4.5-6 \mu \mathrm{m}$ in water, and (9-)10-13(-14) $\times$ (5-)5.5-7(-8) $\mu \mathrm{m}$ in $\mathrm{K}$, ascospores septum (1.5-)1.75-2.5(-3) $\mu \mathrm{m}$ in water and becoming much wider to (2.5-)3-6 $\mu \mathrm{m}$ in $\mathrm{K}$. Conidiomata with darkish orange/reddish portion at the ostiole/tips, to $100 \mu \mathrm{m}$ diam. and to $170 \mu \mathrm{m}$ high; conidia widely ellipsoid or widely bacilliform (2.5-)3.2-4.0 × 1.2-1.5(-1.8) $\mu \mathrm{m}$. Chemistry: Cortical layer of thallus and thalline exciple, epihymenium and outermost portion of true exciple $\mathrm{K}+$ purple, sometimes blackish purple in places (Fig. 5). Etymology: It is named after type locality of this species, i.e. Uttarkashi district, of Uttarakhand, India, South Asia. Ecology and distribution: Saxicolous species growing on siliceous rocks between elevations of 200-1,980 m in tropical to temperate regions of Himachal Pradesh, Rajasthan, Tamil Nadu, Uttar Pradesh, Uttaranchal and Uttarakhand.

Taxonomic notes: Squamulea uttarkashiana is similar to Huriella loekoesiana S. Y. Kondr. et D. K. Upreti in having somewhat areolate thallus, and in having biatorine and lecanorine apothecia within the same thallus, but differs in having narrower ascospore septum (1.5-)1.75-2.5(-3) $\mu \mathrm{m}$ (vs. (3.5-)4-5(-6) $\mu \mathrm{m}$ wide), as well as in forming separate branch within the Squamulea clade of the subfamily Xanthorioideae, while apothecia (0.2-)0.3-0.4(-0.6) $\mathrm{mm}$ (vs. 0.2$0.4(-0.5) \mathrm{mm}$ diam.), and ascospores (8-)10-10.5 × 4.5-6 $\mu \mathrm{m}$ vs. (8.5-)9-11(-12) $\times(4.5) 5-6 \mu \mathrm{m})$ are almost the same (Kondratyuk et al. 2017a). Squamulea uttarkashiana is similar to $S$. squamosa, but differs in having narrower ascospores

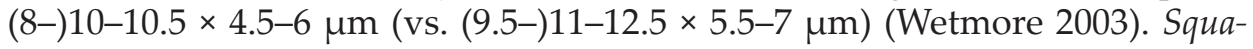
mulea uttarkashiana is similar to $S$. subsoluta, but differs in having narrower ascospores (8-)10-10.5 × 4.5-6 $\mu \mathrm{m}$ (vs. 9.5-12.5 × 5.5-7 $\mu \mathrm{m}$ ) (after Wetmore 2003). Squamulea uttarkashiana is similar to Huriella pohangensis S. Y. Kondr., L. Lőkös et J.-S. Hur, but differs in having a smaller number of apothecia per thalline areole (1-4 per areole) (vs. usually $1-7(-12)$ per areole), and in having lecanorine apothecia with dull brownish disc (vs. zeorine apothecia with reddish orange disc), and in having smaller ascospores (8-) 10-10.5 × 4.5-6 $\mu \mathrm{m}$ (vs (9-) 12-14(-15) × (5.8-) 6-7 $\mu \mathrm{m})$ (Kondratyuk et al. 2018b). Squamulea uttarkashiana is positioned in the outermost position to all known Squamulea species in molecular analysis of nrITS of voucher specimens (SK J18 and SK J19). Its status will be clarified more precisely, when nrLSU and mtSSU data will be available for this material.

Representative specimens examined: Himachal Pradesh, Parbati River valley, ca 1,950 m, 18.06.1975, D. D. Awasthi \& K. Dange, LWG-75109; Kangra district., Palampur Banchal, alt. 1,200 m, 12.05.2001, D. K. Upreti \& S. Nayaka LWG-0175202. - Rajasthan, Sirohi district, Mt Abu, Crumukh, $24^{\circ} 34^{\prime} 30.8^{\prime \prime}$ N, $72^{\circ} 43^{\prime} 10.3^{\prime \prime}$ E, 1,164 m a.s.l., on rock growing together with Caloplaca abuensis and Megaspora subpoliotera, 21.03.2015, Upreti \& R. Bajpai, LWG-15-025996; on rock, 15.09.1985, D. D. Awasthi \& G. Awasthi, LWG-85.22, 10.06.1978, S. R. Singh, LWG-78.79. - Tamil Nadu, Salem district, Palamalai Hills, Sidheswas Mardir $11^{\circ} 41^{\prime} 33.4^{\prime \prime}$ N, $77^{\circ} 44^{\prime} 8.5^{\prime \prime}$ E, 1,480 m a.s.l., on rock, 24.07.2012, J. Aacharya, 
LWG-12-028139. - Uttarakhand, Dehradun district, Mussoorie Hills, alt. 7,500 ft, 26.10.1975, M. Joshi, LWG-75.336; Mohalla-Thaplia, on tin sheet of roof, 05.06.1992, D. K. Upreti, LWGL-13212, LWG-L-13212, Uttarkashi district, Govind Wildlife Sanctuary, en route to Ruinana, $3 \mathrm{~km}$ from Oola, 31 06' 41.9" N, 78 19' 44.25" E, $268 \mathrm{~m}, 04.06 .2013$, R. Bajpai, LWG13-019808, 12.10.2015, K. K. Ingle, LWG-15-019808; Chamoli district, Joshimath, Jogifall, 22.06.2005, V. Shukla \& Y. Joshi, LWG-05-005947.

\section{Teloschistes Norm.}

Type: Teloschistes flavicans (Sw.) Norman

The genus Teloschistes comprises about 151 species in the world (Søchting and Frödén 2002), however, genera Niorma A. Massal. and Teloschistopsis Frödén, Søchting et Arup were recently segregated from this genus (Arup et al. 2013, Kondratyuk et al. 2013a). One single species has been reported from India (Awasthi 1988, Singh and Sinha 2010).

Teloschistes flavicans (Swartz) Norman, Nytt Mag. Naturvidensk. 7: 229 (1853). - Thallus fruticose to subfruticose to appressed and spreading, corticolous, fairly large, $2.0-7.0(-10.0) \mathrm{cm}$ in diameter, pale yellow to orange to reddish orange or more rarely pale grey; sorediate, soredia basically farinose to granular, yellow to whitish, soralia orbicular to elongated apothecia not seen. Chemistry: Thallus $\mathrm{K}+$ purple, $\mathrm{KC}-, \mathrm{C}-, \mathrm{Pd}-, \mathrm{I}-$ : anthraquinones: parietin (major), teloschistin, fallacinal, parietinic acid, erythroglaucin and emodin; depsidones: caloploicin (major), vicanicin, isofulgidin present in TLC. Ecology and distribution: It is widely distributed in warm subtropical to temperate regions of Karnataka, Kerala and Tamil Nadu.

Representative specimens examined: Karnataka, Shimoga district, Sagar Hosagunda Sacred Grove, alt. 624 m, on bark, 29.01.2019, D. K. Upreti, G. K. Mishra \& S. Dudani, LWG19-029319; Mysore, 15.10.1956, D. D. Awasthi, LWG-AWAS-3590. - Kerala, Idukki district, Thenmallay, Tea-Estate area, near Munnar, along roadside, alt. 1,800 m, 26.03.1985, D. D. Awasthi, R. Tewari \& R. Mathur, LWG-LWU-85.344. - Tamil Nadu, Madurai district, Shembaganur-Kodaikanal, alt. 1,950 m, 22.12.1959, G. Foreau \& D. D. Awasthi, LWG-AWAS-4288; Kodaikanal, alt. 2,100 m, on trees and shrubs, 20.12.1959, D. D. Awasthi, LWG-AWAS-4413.

Upretia S. Y. Kondr., A. Thell et J.-S. Hur

Type: Upretia amarkantakana (Joshi et Upreti) S. Y. Kondr. et A. Thell

Genus Upretia is so far known only from India and is represented by two species (Kondratyuk et al. 2018a), while it may include more members from the Himalayan region. Caloplaca cupreorufa Zahlbr., known from China (Zahlbruckner 1930), and C. cupreobrunnea Poelt et Hinter., known from Nepal (Poelt and Hinteregger 1993), may belong to Upretia after having distinctly 
brownish thallus, as well as brownish pigment in walls of outer cortical cells too. Unfortunately, these two taxa are imperfectly known and no molecular data are available for these species so far.

1 Thallus rather thick, distinctly lobate in peripheral zone

U. amarkantakana

- Thallus thinner, more or less squamulose or areolate

U. hueana

Upretia amarkantakana (Y. Joshi et Upreti) S. Y. Kondr. et A. Thell, Crypt. Biodiv. Assessm. (Spec. Vol.), p. 30 (2018). - Thallus lobate to subsquamulose, olivaceous grey to olivaceous brown, \pm pruinose, lacking necral layer, ascospores 8.5-10 × 4-5 $\mu \mathrm{m}$, conidia 1-3 × 0.5-1 $\mu \mathrm{m}$ (for more description see Joshi 2008, Kondratyuk et al. 2018a). Chemistry: Thallus and thalline margin $\mathrm{K}-, \mathrm{KC}-, \mathrm{C}-, \mathrm{Pd}-$; apothecial disc and epihymenium $\mathrm{K}+$ purple, $\mathrm{C}-$, $\mathrm{Pd}-$ : parietin present in apothecial disc and an olive-green spot at Rf class 4 present in TLC. Ecology and distribution: Saxicolous species growing on exposed bauxite rocks between altitudes of 500-600 m in Madhya Pradesh.

Representative specimens examined: Madhya Pradesh, Anuppur district, Amarkantak, Kapildhara area, alt. 603 m, on rock, 23.03.2004, D. K. Upreti, S. Nayaka \& Satya, LWG-04-002808, LWG-04-002870; Dindori district, Khurkhuridader, alt. 500 m, on rock, 07.07.2005, D. K. Upreti, S. Nayaka \& Satya, LWG-05-005750; Shahdol district, Amarkantak, Kapildhara, on rock, 27.09.1987, D. K. Upreti, LWG-201722.

Upretia hueana (B. de Lesd.) S. Y. Kondr. et Upreti, comb. nova-MycoBank No.: MB 832451 - Basionym: Caloplaca hueana B. de Lesd., Lich. Mexique, p. 12 (1914). - This species is characterised by squamulose to lobed glossy thallus with brown external necral layer, brown apothecial disc margins concolorous with thallus, hypothecium with oil globules, parathecium of irregularly rounded to elongated cells, algae in upper amphithecium, paraphyses not branched, tips with 1-3 swollen cells, ascospores 8.5-11.0(-12.0) $\times 5.1-8.5 \mu \mathrm{m}$, isthmus 1.5-2.5 $\mu \mathrm{m}$, ostiole brownish black, conidia 3-4 $\times 1 \mu \mathrm{m}$ (Joshi 2008). Chemistry: Thallus and apothecial disc $\mathrm{K}_{-}, \mathrm{KC}-, \mathrm{C}_{-}, \mathrm{Pd}-$, epihymenium $\mathrm{K}+$ purple: parietin in apothecial disc present in TLC. Ecology and distribution: Saxicolous species growing at an altitude of 1,050 m in Madhya Pradesh.

Representative specimen examined: Madhya Pradesh, Hoshangabad district, Pachmarhi, on the way to Pancy pool, alt. ca 1,050 m, on rock, 23.01.1973, S. R. Singh, LWG-LWU-73.4.

\section{Wetmoreana Arup, Søchting et Frödén}

Type: Wetmoreana texana (Wetmore et Kärnefelt) Arup, Frödén et Søchting

The genus Wetmoreana is represented by four species in the world (Arup et al. 2013, Kondratyuk et al. 2013a), of which one is reported from India. 
Wetmoreana appressa (Wetmore et Kärnefelt) Arup, Frödén et Søchting, Nordic J. Bot. 31(1): 66 (2013). - This species is characterised by tightly appressed, orange to yellowish orange, effigurate thallus having convex areoles in central portion (Joshi 2008). Chemistry: Thallus, apothecial disc and epihymenium $\mathrm{K}+$ red, C-, Pd-: parietin present in TLC. Ecology and distribution: Saxicolous species growing on non-calcareous rocks at an altitude of 2,000 $\mathrm{m}$ in temperate regions of the Western Himalayas in exposed habitats in Jammu \& Kashmir.

Representative specimen examined: Jammu \& Kashmir, Anantnag district, Pahalgam, S side, alt. 2,000 m, on exposed rocks, 31.07.2005, M. Sheikh, LWG-05-006691.

\section{Xanthaptychia S. Y. Kondr. et Ravera}

Type: Xanthaptychia orientalis (Frödén) S. Y. Kondr. et Ravera

Four species of the genus Xanthaptychia are known in the world (Kondratyuk et al. 2017b). A single species is known from India.

Xanthaptychia contortuplicata (Ach.) S. Y. Kondr. et Ravera, Acta Bot. Hung. 59(1-2): 123 (2017). - The species is characterised by foliose to subfruticose thallus, isidia-like structures (blastidia), yellow to deep orange, often largely grey upper surface; pale grey to white or yellow at the lobe tips on lower surface; apothecial disc darker than the thallus often becoming reddish orange, ascospores hyaline, oblong to narrowly ellipsoid, 13-17 × 7-9 $\mu \mathrm{m}$. Chemistry: Thallus, apothecial disc and epihymenium $\mathrm{K}+$ purple, $\mathrm{C}-, \mathrm{Pd}-$ : parietin (major), fallacinal, teloschistin, and parietinic acid (all minor), and emodin (minor) present in TLC. Ecology and distribution: Corticolous species growing in temperate and subtemperate regions of Himachal Pradesh, Jammu \& Kashmir \& Uttarakhand.

Representative specimens examined: Himachal Pradesh, Lahul Spiti district, Spiti Vally, Po village, close to village, on boulders, 24.07.1952, O. A. Höeg, LWG-AWAS1558; Kangra district, Po village, on rock, 24.07.1952, O. A. Höeg, LWG-AWAS-1556. - Jammu \& Kashmir, Leh district, Dihar Leh, alt. 3,886 m, on rock, 15.08.2010, J. Kumar, LWG-10-014384. - Uttarakhand, Chamoli district, Malari, on rock, 24.09.2006, S. Rawat, LWG-06-00677.

\section{Xanthoria (Fr.) Th. Fr.}

Type: Xanthoria parietina (L.) Th. Fr.

The genus Xanthoria has a diversity between 6 and 12 species in the world (Arup et al. 2013, Kondratyuk et al. 2013b, 2014b, 2017a). One species is known from India.

Xanthoria parietina (L.) Th. Fr., Lich. Arctoi 3: 69 (1860). - It is easily recognised by large esorediate thallus, \pm firmly (but not tightly) attached with 
short hapters, wide and \pm concave wrinkled lobes and ellipsoid conidia (Joshi 2008). Chemistry: Upper surface $\mathrm{K}+$ purple, $\mathrm{KC}-, \mathrm{C}-, \mathrm{Pd}-$, I-: parietin (major), fallacinal, emodin, teloschistin and parietinic acid present in TLC. Ecology and distribution: It grows generally on various phorophytes as well as on rocks in Himachal Pradesh, Jammu \& Kashmir, Tamil Nadu and Uttarakhand.

Representative specimens examined: Jammu \& Kashmir, Anantnag district, Pahalgam, alt. 2,000 m, on bark of tree, 01.11.1953, D. D. Awasthi, LWG-AWAS-2623; on the way to Aru, alt. ca 2,400 m, on bark of tree trunk, 28.06.1977, K. Dange, LWG-LWU-77.184A; Pulwama district, Pingalgam, alt. 1,584 m, on moss, 07.2004, M. Sheikh, LWG-04-004853. - Uttarakhand, Pithoragarh district, between Milam and Martoli, alt. 3,000 m, on rock, 01.07.1973, A. Singh, LWG-102845.

\section{Zeroviella S. Y. Kondr. et J.-S. Hur}

Type: Zeroviella papillifera (Vain.) S. Y. Kondr. et J.-S. Hur

About eight species of genus Zeroviella are known in the world (Kondraryuk et al. 2015e), of which a single species is reported from India.

Zeroviella esfahanensis S. Y. Kondr., B. Zarei-Darki et J.-S. Hur, Ukr. Bot. J. $72(6)$ : 579 (2015). - Thallus foliose, often distinctly rosette-like, lobes 3-5(-7) $\mathrm{mm}$ long, (0.5-)0.7-1.5 mm wide, lower surface often undulating, in section resembling hapter-like formations; upper surface uneven owing to numerous pseudocyphellae, apothecia 1.0-1.5 mm diam., lecanorine, disc more or less slightly convex, ascospores 1-septate, mainly ellipsoid with rounded ends and rounded cell lumina, (8-)9.5-13.5 × (4-)6.5-8.5 $\mu \mathrm{m}$. Chemistry: Thallus, apothecial disc and epihymenium $\mathrm{K}+$ red, $\mathrm{C}-$, $\mathrm{Pd}-$-: parietin (major), teloschistin, fallacinal, parietinic acid and emodin (traces) present in TLC. Ecology and distribution: The species is distributed in different states of Himachal Pradesh, Jammu \& Kashmir and Uttarakhand.

Representative specimens examined: Himachal Pradesh, Lahul Spiti district, Lahul valley, $11 \mathrm{~km}$ before Kunzum Pass, alt. 4,000 m, on rock, 06.08.2002, D. K. Upreti \& P. K. Divakar, LWG-02-000134. - Jammu \& Kashmir, Anantnag district, Pahalgam, on the way to Chandanwari, alt. 2,700 m, on boulders, 29.06.1977, K. Dange, LWG-LWU-77.296, Udhampur district, Patnitop, Sanasar area, 16 km from Patnitop, alt. 2,500 m, on rock, 10.12.2005, M. Sheikh, LWG-10-029655. - Uttarakhand, Chamoli district, Badrinath, Mana village, on rock, 21.06.2005, V. Shukla \& Y. Joshi, LWG-05-005253, LWG-05-005383; Malari, on the way to Niti, alt. 3,086 m, on rock, 19.8.2007, D. K. Upreti \& S. Nayaka, LWG-07-011225; Malari, on rock, 24.06.2007, S. Rawat, LWG-07-008620, LWG-07-008609.

\section{Excluded species}

Megaspora subpoliotera (Y. Joshi et Upreti) S. Y. Kondr., Upreti et A. Thell, comb. nova (Figs 9-11) - MycoBank No.: MB 832445 - Basionym: Caloplaca subpoliotera Y. Joshi et Upreti, Nova Hedwigia 86(1-2): 269 (2008). Type: 


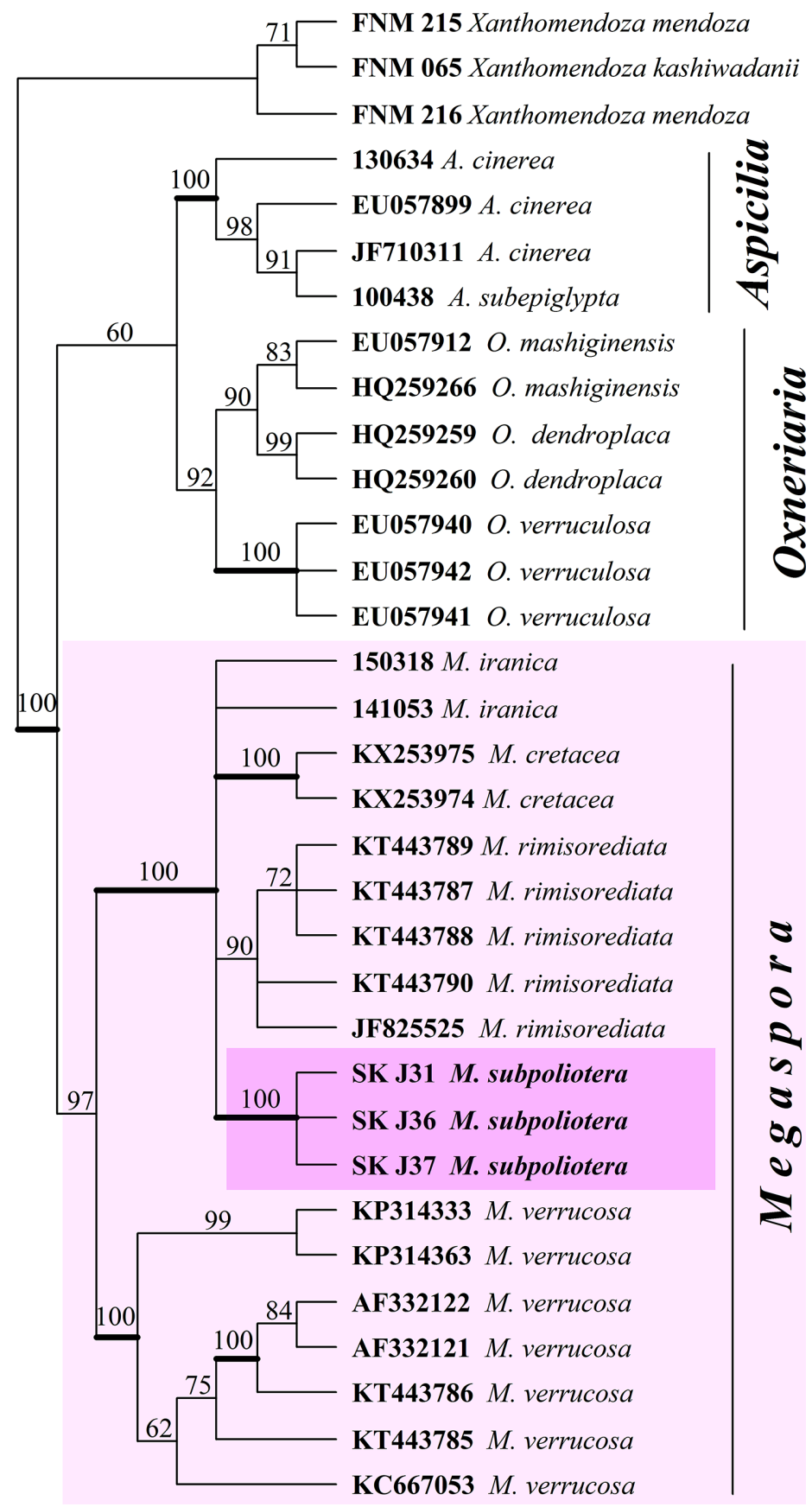

Fig. 9. Position of Megaspora subpoliotera in phylogenetic tree of the Megasporaceae based on nrITS sequences 
India, Madhya Pradesh, Raisen district, Bhimbetka Main Cave area, alt. ca 522 m, 10.10.2004, Upreti \& Joshi 04-4432/B (holotype: LWG; isotype: CAL). - According to the original description of Joshi and Upreti (2008) this species is characterised by a rimose-areolate grey thallus with whitish soredia, orange-red apothecial disc and a black proper margin. However, the sorediate thallus belongs to Megaspora species, while apothecia may belong to Caloplaca poliotera group based on molecular analysis. Chemistry: Thallus $\mathrm{K}+$ yellow, $\mathrm{KC}-, \mathrm{C}-, \mathrm{Pd}-$; apothecial disc and epihymenium $\mathrm{K}+$ purple: atranorin and ol-

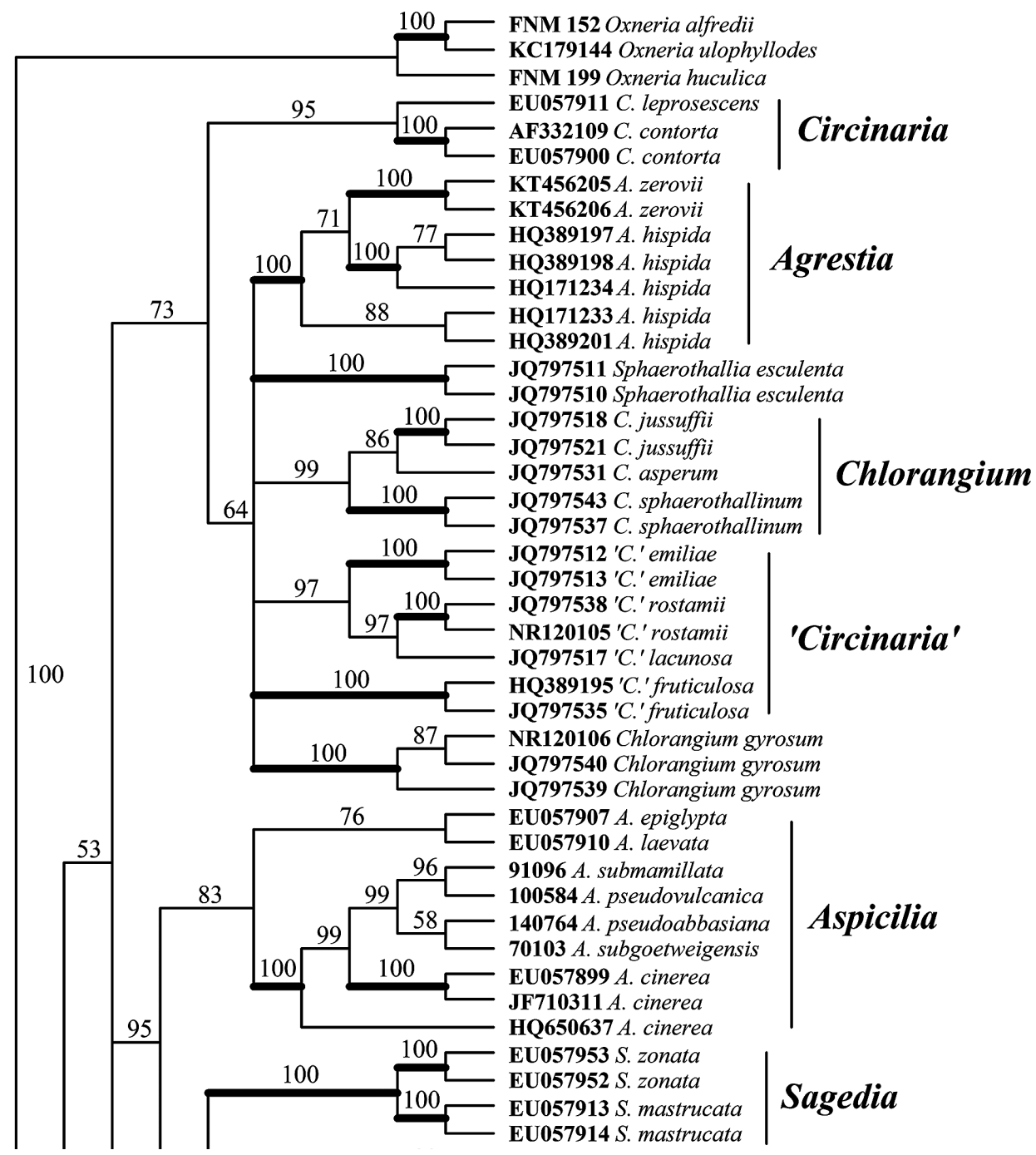

Fig. 10. Position of Megaspora subpoliotera in combined phylogenetic tree of the Megasporaceae based on nrITS, nrLSU and mtSSU sequences 


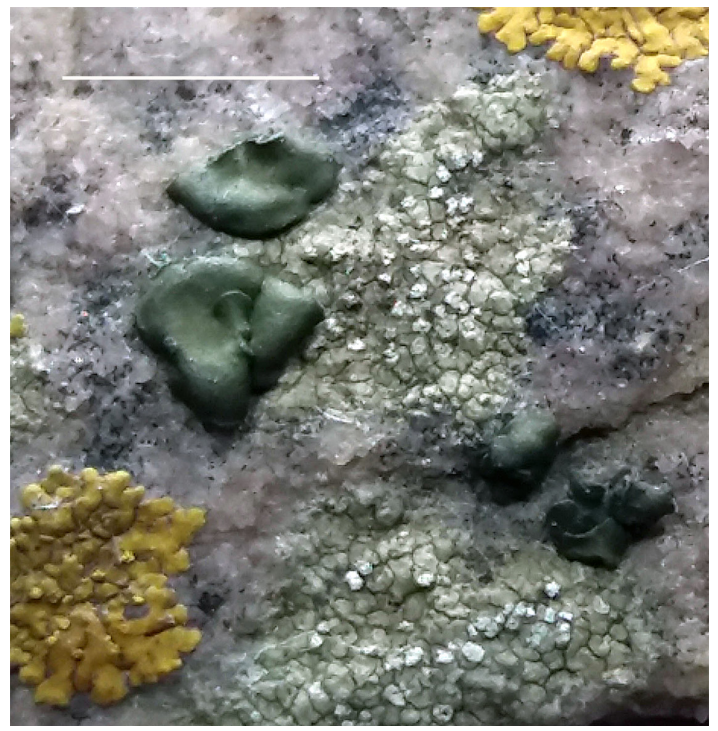

ive spot at Rf 4 present in TLC. Ecology and distribution: Saxicolous species growing on exposed quartzite, granite and non-calcareous rocks in association with Peltula euploca, Caloplaca cupulifera and Squamulea subsoluta at an elevation of 600 $\mathrm{m}$, in dry tropical regions of Madhya Pradesh, Maharashtra, Orissa and Uttar Pradesh. Taxonomic notes: Based on molecular analysis, i.e. nrITS phylogenetic study (Fig. 9) and

Fig. 11. Megaspora subpoliotera (holotype, LWG) habitat. Scale bar $=2 \mathrm{~mm}$

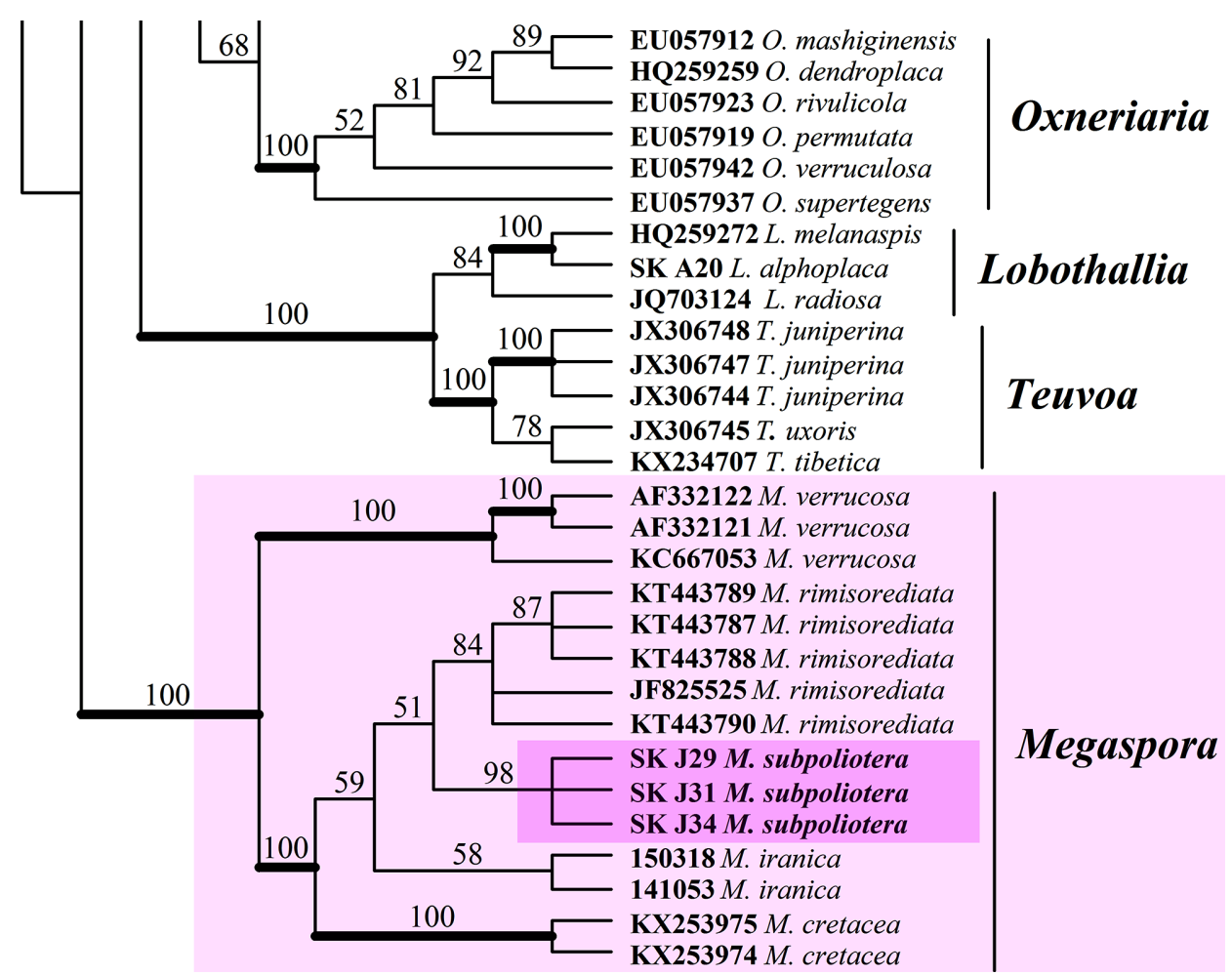

Fig. 10 (continued) 
combined phylogenetic tree based on nrITS, nrLSU and mtSSU sequences (Fig. 10), this species belongs to the Megasporaceae Lumbsch, i.e. to the Megaspora rimisorediata branch including $M$. iranica Haji Moniri et S. Y. Kondr., in Haji Moniri, Gromakova, Lőkös et Kondratyuk, M. rimisorediata Valadb. et A. Nordin, in Valadbeigi, Nordin et Tibell, M. cretacea Gasparyan, Zakeri et Aptroot, in Zakeri, Gasparyan et Aptroot of the genus Megaspora (Clauzade et $\mathrm{Cl}$. Roux) Hafellner et V. Wirth.

Representative specimens examined: Madhya Pradesh, Raisen district, Bhimbetka, Rang Mahal area, D. K. Upreti, LWG-04-003515; Bhimbetka Main Cave area, D. K. Upreti \& Y. Joshi, LWG-04-004415. - Maharashtra, Pune city, Taljai, Parvati Paschgaon, alt. 580 m, on rock, 31.02.2006, S. Nayaka, LWG-06-005066. - Orissa, Puri district, Bhubaneshwar, Kotiturth temple, A. Singh, S. Chatterjee \& M. Rastogi, LWG-93.13. - Tamil Nadu, Kalkotti, Siruvani Hills, alt. 450 m, on rocks, 26.06.1997, G. N. Hariharan, MSSRF-CS1. - Uttar Pradesh, Mahoba district, Bukhra Pahar, D. K. Upreti, Z. H. Khan \& S. Dwivedi, LWG-20-104877.

\section{CONCLUSIONS}

The present revisionary study treated and reported 115 species from India. The teloschistoid lichens are forming a unique group of taxa, due to living among various environmental conditions, representing a wide range of growth forms, habitats and distribution patterns. Thus, the species occur from arid regions to the Eastern Himalayas and from the coastal region up to the alpine zone. Among the different genera in the family, Caloplaca species are present in all the phytogeographical regions of India, whereas Oxneria, Rusavskia and Xanthoria are found in the subalpine region in the country. Among the 115 species known from India, 23 species are supposedly endemic to the country. Furthermore, several species complexes in the genera Caloplaca, Rusavskia, Xanthoria, Zeroviella of Indian lichen biota still are waiting for special revision. Including the same molecular markers for the further revision of taxa which were included here under the genus Caloplaca will allow to clarify species diversity of the genera Mikhtomia, Oxneriopsis, Upretia, as well as some others.

Acknowledgements - We are thankful to the Director, CSIR-National Botanical Research Institute, Lucknow for providing facilities and Department of Science and Technology, New Delhi (INT/UKR/P-19/2015) to DKU and SN; for their kind help, to Dr M.-H. Jeong, Ms S.-H. Jang and Mr D. Liu (KoLRI, Sunchon, South Korea), Mr P.-E. Persson, and Prof. M. Hansson (Lund, Sweden) for their kind help with providing molecular data on some voucher specimens, and to Dr E. Farkas (Vácrátót, Hungary) for the kind possibility to make photos. The project was also supported in parts by the Ministry of Education and Science of Ukraine (M/90-2015-285, M/34-2016-285, M/172-2017-287, M/53-2019-298 and M/30-2020298), and by the Korean National Research Foundation (NRF-2018K1A3A1A13087249). 


\section{REFERENCES}

Ahti, T., Kondratyuk, S. Y., Kärnefelt, I. and Thell, A. (2015): Nomenclatural corrections and notes on some taxa in the Teloschistaceae (lichenised Ascomycetes). - Graphis Scripta 27(1-2): 37-41.

Alon, G. and Galun, M. (1971): The genus Caloplaca in Israel. - Israel J. Bot. 20: 273-292.

Arup, U. (1995a): Littoral species of the lichen genus Caloplaca in North America. - PhD thesis, Lund University, Lund.

Arup, U. (1995b): Eight species of Caloplaca in coastal western North America. - Bryologist 98: 92-111. https://doi.org/10.2307/3243645

Arup, U., Søchting, U. and Frödén, P. (2013): A new taxonomy of the family Teloschistaceae. - Nordic J. Bot. 31(1): 16-83. https://doi.org/10.1111/j.1756-1051.2013.00062.x

Awasthi, D. D. (1965): Catalogue of lichens from India, Nepal, Pakistan, and Ceylon. - Beih. Nova Hedwigia 17: 1-137.

Awasthi, D. D. (1988): A key to the macrolichens of India and Nepal. - J. Hattori Bot. Lab. 65: 207-302.

Awasthi, D. D. (1991): A key to the microlichens of India, Nepal and Sri Lanka. - Bibl. Lichenol. 40: 1-337.

Balaji, P. and Hariharan, G. N. (2005): Annotated checklist of the lichens of Chennai, Tamil Nadu, India. - Phytotaxonomy 5: 1-7.

Ekanayaka, A. H., Hyde, K. D., Jones, E. B. G., Zhao, Q. and Bulgakov, T. S. (2019): New and known discolichens from Asia and eastern Europe. - Asian J. Mycol. 2(1): 48-86. https://doi.org/10.5943/ajom/2/1/2

Ekman, S. (1999): PCR optimisation and troubleshooting, with special reference to the amplification of ribosomal DNA in lichenized fungi. - Lichenologist 31(5): 517-531. https://doi.org/10.1017/s0024282999000675

Fedorenko, N. M., Stenroos, S., Thell, A., Kärnefelt, I. and Kondratyuk, S. Y. (2009): A phylogenetic analysis of xanthorioid lichens (Teloschistaceae, Ascomycota) based on ITS and mtSSU sequences. - Bibl. Lichenol. 100: 49-84.

Fedorenko, N. M., Stenroos, S., Thell, A., Kärnefelt, I., Elix, J. A., Hur, J.-S. and Kondratyuk, S. Y. (2012): Molecular phylogeny of xanthorioid lichens (Teloschistaceae, Ascomycota), with notes on their morphology. - Bibl. Lichenol. 108: 45-64.

Gardes, M. and Bruns, T. D. (1993): ITS primers with enhanced specificity for basidiomycetes - application to the identification of mycorrhizae and rusts. - Mol. Ecol. 2: 113118. https://doi.org/10.1111/j.1365-294x.1993.tb00005.x

Gaya, E., Högnabba, F., Holguin, Á., Molnár, K., Fernández-Brime, S., Stenroos, S., Arup, U., Søchting, U., van den Boom, P., Lücking, R., Sipman, H. J. M. and Lutzoni, F. (2012): Implementing a cumulative supermatrix approach for a comprehensive phylogenetic study of the Teloschistales (Pezizomycotina, Ascomycota). - Mol. Phyl. Evol. 63: 374-387. https://doi.org/10.1016/j.ympev.2012.01.012

Joshi, Y. (2008): Morphotaxonomic studies on lichen family Teloschistaceae from India. - PhD thesis, Kumaon University, Nainital.

Joshi, Y. and Upreti, D. K. (2007a): New species and new records of the lichen genus Caloplaca from India. - Lichenologist 39(6): 505-508. https://doi.org/10.1017/ S0024282907006834

Joshi, Y. and Upreti, D. K. (2007b): Caloplaca awasthii, a new lichen species from India. Bot. J. Linn. Soc. 155(1): 149-152. https://doi.org/10.1111/j.1095-8339.2007.00683.x 
Joshi, Y. and Upreti, D. K. (2008): Sorediate and isidiate species of the lichen genus Caloplaca (Ascomycetes, Teloschistaceae) from India. - Nova Hedwigia 86(1-2): 259-272. https://doi.org/10.1127/0029-5035/2008/0086-0259

Joshi, Y., Jagadeesh Ram, T. A. M. and Sinha, G. P. (2012): Caloplaca gyrophorica (lichenized Ascomycota), a new saxicolous species from India. - Mycotaxon 122: 303-306. https:// doi.org/10.5248/122.303

Joshi, Y., Jagadeesh Ram, T. A. M., Singh, P. and Sinha, G. P. (2014): Caloplaca indica, new lichenized Ascomycetes (Teloschistaceae) from Eastern Himalaya, India. - Nat. Acad. Sci. Letters 37(6): 517-519. https://doi.org/10.1007/s40009-014-0270-3

Kärnefelt, I. (1989): Morphology and phylogeny in the Teloschistales. - Crypt. Botany 1: 147-203.

Kholia, H., Mishra, G. K., Upreti, D. K. and Tiwari, L. (2012): Diversity and distribution of lichen in and around Nainital city, Nainital District, Uttarakhand. - The Indian Forester 138(5): 443-448.

Kondratyuk, S. Y. and Kärnefelt, I. (1997): Josefpoeltia and Xanthomendoza, two new genera in the family Teloschistaceae (Ascomycotina). - Bibl. Lichenol. 68: 19-44.

Kondratyuk, S. Y. and Kärnefelt, I. (2003): Revision of three natural groups of xanthorioid lichens (Teloschistaceae, Ascomycota). - Ukr. Bot. Zh. 60(4): 427-437.

Kondratyuk, S. and Poelt, J. (1997): Two new Asian Xanthoria species (Teloschistaceae, lichenized Ascomycotina). - Lichenologist 29: 173-190. https://doi.org/10.1017/ S0024282997000200

Kondratyuk, S. Y., Oxner, A. N. and Khodosovtsev, A. Y. (2004): Caloplaca. - In: Khodosovtsev, A. Y., Kondratyuk, S. Y., Makarova, I. I. and Oxner, A. N. (eds): Handbook of the lichens of Russia. 9. Fuscideaceae, Teloschistaceae. Nauka, Sankt-Petersburg, pp. 38-236.

Kondratyuk, S. Y., Kärnefelt, I., Goward, T., Galloway, D., Kudratov, I. et al. (2010): Addendum 1. Diagnoses of new taxa. - In: Oxner, A. M.: Flora of the lichens of Ukraine. Vol. 2(3). Naukova Dumka, Kyiv, pp. 435-445.

Kondratyuk, S. Y., Zarei-Darki, B. and Khajeddin, S. J. (2011): Two new Zwackhiomyces (Xanthopyreniaceae, Ascomycota) species of lichenicolous fungi from Esfahan Province. - Ukr. Bot. J. 68(5): 833-842.

Kondratyuk, S. Y., Jeong, M.-H., Yu, N.-H., Karnefelt, I., Thell, A., Elix, J., Kim, J., Kondratiuk, A. S. and Hur, J.-S. (2013a): Four new genera of teloschistoid lichens (Teloschistaceae, Ascomycota) based on molecular phylogeny. - Acta Bot. Hung. 55(3-4): 251-274. https://doi.org/10.1556/ABot.55.2013.3-4.8

Kondratyuk, S. Y., Yatsyna, A. P., Lőkös, L., Galanina, I., Haji Moniri, M. and Hur, J.-S. (2013b): Three new Xanthoria and Rusavskia species (Teloschistaceae, Ascomycota) from Europe. - Acta Bot. Hung. 55(3-4): 351-365. https://doi.org/10.1556/ ABot.55.2013.3-4.10

Kondratyuk, S. Y., Jeong, M.-H., Yu, N.-N., Kärnefelt, I., Thell, A., Elix, J. A., Kim, J., Kondratiuk, A. S. and Hur, J.-S. (2014a): A revised taxonomy for the subfamily Caloplacoideae (Teloschistaceae, Ascomycota), based on molecular phylogeny. - Acta Bot. Hung. 56(1-2): 93-123. https://doi.org/10.1556/ABot.56.2014.1-2.10

Kondratyuk, S. Y., Kärnefelt, I., Thell, A., Elix, J. A., Kim, J., Jeong, M.-H., Yu, N.-N., Kondratiuk, A. S. and Hur, J.-S. (2014b): A revised taxonomy for the subfamily Xanthorioideae (Teloschistaceae, Ascomycota), based on molecular phylogeny. - Acta Bot. Hung. 56(1-2): 141-178. https://doi.org/10.1556/abot.56.2014.1-2.12 
Kondratyuk, S. Y., Jeong, M.-H., Galanina, I. A., Yakovchenko, L. S., Yatsyna, A. P. and Hur, J.-S. (2014c): Molecular phylogeny of placodioid lichen-forming fungi reveal a new genus, Sedelnikovaea. - Mycotaxon 129(2): 269-282. https://doi.org/10.5248/129.269

Kondratyuk, S. Y., Kärnefelt, I., Thell, A., Elix, J. A., Kim, J., Kondratiuk, A. S. and Hur, J.-S. (2015a): Tassiloa, a new genus in the Teloschistaceae (lichenized Ascomycetes). - Graphis Scripta 27(1-2): 22-26.

Kondratyuk, S. Y., Lőkös, L., Farkas, E., Oh, S.-O. and Hur, J.-S. (2015b): New and noteworthy lichen-forming and lichenicolous fungi 2. - Acta Bot. Hung. 57(1-2): 77-141. https://doi.org/10.1556/ABot.57.2015.1-2.10

Kondratyuk, S. Y., Lőkös, L., Kim, J. A., Kondratiuk, A. S., Jeong, M.-H. Jang, S. H., Oh, S.-O. and Hur, J.-S. (2015c): Three new monotypic genera of the caloplacoid lichens (Teloschistaceae, lichen-forming Ascomycetes). - Mycobiology 43(3): 195-202. https:// doi.org/10.5941/myco.2015.43.3.195

Kondratyuk, S. Y., Kärnefelt, I., Thell, A., Elix, J. A., Kim, J., Kondratiuk, A. S. and Hur, J.-S. (2015d): Brownlielloideae, a new subfamily in the Teloschistaceae (Lecanoromycetes, Ascomycota). - Acta Bot. Hung. 57(3-4): 321-343. https://doi.org/10.1556/034.57.2015.3-4.6

Kondratyuk, S. Y., Kim, J. A., Yu, N.-H., Jeong, M.-H., Jang, S. H., Kondratiuk A. S., Zarei-Darki, B. and Hur, J.-S. (2015e): Zeroviella, a new genus of xanthorioid lichens (Teloschistaceae, Ascomycota) proved by three gene phylogeny. - Ukr. Bot. J. 72(6): 574-584. https://doi.org/10.15407/ukrbotj72.06.574

Kondratyuk, S. Y., Mishra, G. K., Nayaka, S. and Upreti, D. K. (2016): New record or otherwise interesting species of Teloschistaceae (lichenized fungi) from India. - Crypt. Biodiv. Assessm. 2(1): 8-13. https://doi.org/10.21756/cab.v2i01.8611

Kondratyuk, S. Y., Lőkös, L., Upreti, D. K., Nayaka, S., Mishra, G. K., Ravera, S., Jeong, M.-H., Jang, S.-H., Park, J. S. and Hur, J.-S. (2017a): New monophyletic branches of the Teloschistaceae (lichen-forming Ascomycota) proved by three gene phylogeny. Acta Bot. Hung. 59(1-2): 71-136. https://doi.org/10.1556/034.59.2017.1-2.6

Kondratyuk, S. Y., Lőkös, L., Halda, J. P., Roux, C., Upreti, D. K., Schumm, F., Mishra, G. K., Nayaka, S., Farkas, E., Park, J. S., Lee, B. G., Liu, D., Woo, J.-J. and Hur, J.-S. (2017b): New and noteworthy lichen-forming and lichenicolous fungi 6. - Acta Bot. Hung. 59(1-2): 137-260. https://doi.org/10.1556/034.59.2017.1-2.7

Kondratyuk, S. Y., Persson, P.-E., Hansson, M., Mishra, G. K., Nayaka, S., Liu, D., Hur, J.-S. and Thell, A. (2018a): Upretia, a new caloplacoid lichen genus (Teloschistaceae, Lichen-Forming Ascomycota) from India proved by molecular phylogeny. - Crypt. Biodiv. Assessm. (Spec. Vol.): 22-31. https://doi.org/10.21756/cab.esp5

Kondratyuk, S. Y., Lőkös, L., Halda, J. P., Farkas, E., Upreti, D. K., Thell, A., Woo, J.-J., Oh, S.-O. and Hur, J.-S. (2018b): New and noteworthy lichen-forming and lichenicolous fungi 7. - Acta Bot. Hung. 60(1-2): 115-184. https://doi.org/10.1556/034.60.2018.1-2.8

Kondratyuk, S. Y., Kärnefelt, I., Lőkös, L., Hur, J.-S. and Thell, A. (2018c): Coppinsiella and Seawardiella, two new genera of the Xanthorioideae (Teloschistaceae, lichen-forming Ascomycota). - Acta Bot. Hung. 60(3-4): 369-386. https://doi.org/10.1556/034.60.2018.3-4.8

Kondratyuk, S. Y., Lőkös, L., Halda, J., Lee, B. G., Jang, S.-H., Woo, J.-J., Park, J. S., Oh, S.-O., Han, S.-K. and Hur, J.-S. (2019a): Arthonia dokdoensis and Rufoplaca toktoana, two new taxa from Dokdo Islands (South Korea). - Mycobiology 47(4): 355-367. https://doi. org/10.1080/12298093.2019.1688074

Kondratyuk, S. Y., Lőkös, L., Farkas, E., Jang, S.-H., Liu, D., Halda, J., Persson, P.-E., Hansson, M., Kärnefelt, I., Thell, A., Fačkovcová, Z., Yamamoto, Y. and Hur, J.-S. (2019b) 
New and noteworthy lichen-forming and lichenicolous fungi 9. - Acta Bot. Hung. 61(3-4): 325-367. https://doi.org/10.1556/034.61.2019.3-4.6

Kondratyuk, S. Y., Upreti, D. K., Mishra, G. K., Nayaka, S., Ingle, K. K., Orlov, O. O., Kondratiuk, A. S., Lőkös, L., Farkas, E., Woo, J.-J. and Hur, J.-S. (2020a): New and noteworthy lichen-forming and lichenicolous fungi 10. - Acta Bot. Hung. 62(1-2): 69-108. https://doi.org/10.1556/034.62.2020.1-2.6

Kondratyuk, S. Y., Lőkös, L., Farkas, E., Kärnefelt, I., Thell, A., Yamamoto, Y. and Hur, J.-S. (2020b): Three new genera of the Teloschistaceae proved by three gene phylogeny. Acta Bot. Hung. 62(1-2): 109-136. https://doi.org/10.1556/034.62.2020.1-2.7

Laundon, J. R. (1974): Leproplaca in the British Isles. - Lichenologist 6: 102-105. https://doi. org/10.1017/S0024282974000077

Lee, B. G., Kondratyuk, S. Y., Halda, J. P., Lőkös, L., Wang, H.-Y., Jeong, M.-H., Han, S. K., Oh, S.-O. and Hur, J.-S. (2018): Three new species of lichenized fungi from Qinghai Province, China. - Mycotaxon 133: 113-125. https://doi.org/10.5248/133.113

Lohtander, K., Oksanen, I. and Rikkinen, J. (2002): A phylogenetic study of Nephroma (lichen-forming Ascomycota). - Mycol. Research 106: 777-787. https://doi.org/10.1017/ S0953756202006068

Magnusson, A. H. (1940): Lichens from Central Asia. - In: Hedin, S. (ed.): Reports Scientific Exped. NW provinces of China (the Sino-Swedish expedition). 13, XI. Botany, 1. Tryckeri Aktiebolaget Thule, Stockholm, 168 pp.

Magnusson, A. H. (1944): Studies in the ferruginea-group of the genus Caloplaca. - Göteborgs Kungl. Vetensk. Vitterh. Handl., Sjätte Följden, Ser. B 3: 1-71.

Orange, A., James, P. W. and White, F. J. (2001): Microchemical methods for the identification of lichens. - British Lichen Society, London, 101 pp.

Poelt, J. (1977): Ioplaca gen. nov. Teloschistacearum. - Khumbu Himal 6(3): 443-446.

Poelt, J. and Hinteregger, E. (1993): Beiträge zur Kenntnis der Flechtenflora des Himalaya VII. Die Gattungen Caloplaca, Fulgensia und Ioplaca (mit englischem Bestimmungsschlüssel). - Bibl. Lichenol. 50: 1-247.

Sen, V. K. (2014): Assessment of lichen in selected sacred groves of Midnapore district, West Bengal, India. - Int. J. Conserv. Sci. 5(1): 85-94.

Singh, K. P. (1981): Microlichens of Manipur, India. - Geophytology 11: 242-256.

Singh, K. P. and Sinha, G. P. (eds) (2010): Indian lichens: an annotated checklist. - Botanical Survey of India, Ministry of Environment and Forests, Salt Lake City, Kolkata, India, $571 \mathrm{pp}$.

Søchting, U. and Frödén, P. (2002): Chemosyndromes in the lichen genus Teloschistes (Teloschistaceae, Lecanorales). - Mycol. Progress 1: 257-266. https://doi.org/10.1007/ s11557-006-0023-x

Søchting, U. and Lutzoni, F. (2003): Molecular phylogenetic study at the generic boundary between the lichen-forming fungi Caloplaca and Xanthoria (Ascomycota, Teloschistaceae). - Mycol. Research 107: 1266-1276. https://doi.org/10.1017/S0953756203008529

Søchting, U., Sogaard, M. Z., Elix, J. A., Arup, U., Elvebakk, A. and Sancho, L. G. (2014a): Catenarina (Teloschistaceae, Ascomycota), a new Southern Hemisphere genus with 7-chlorocatenarin. - Lichenologist 46(2): 175-187. https://doi.org/10.1017/ S002428291300087X

Søchting, U., Garrido-Benavent, I., Seppelt, R., Castello, M., Pérez-Ortega, S., De Los Ríos Murillo, A., Sancho, L. G., Frödén, P. and Arup, U. (2014b): Charcotiana and Amundsenia, two new genera in Teloschistaceae (lichenized Ascomycota, subfamily Xanthorioideae) hosting two new species from continental Antarctica and Austroplaca 
frigida, a new name for a continental Antarctic species. - Lichenologist 46(6): 763-782. https://doi.org/10.1017/S0024282914000395

Swofford, D. L. (2003): PAUP*, Phylogenetic analysis using parsimony (* and other methods). Sunderland, Sinauer Associates, Massachusetts.

Tamura, K., Peterson, D., Peterson, N., Stecher, G., Nei, M. and Kumar, S. (2011): MEGA5: Molecular evolutionary genetics analysis using maximum likelihood, evolutionary distance, and maximum parsimony methods. - Mol. Biol. Evol. 28: 2731-2739. https:// doi.org/10.1093/molbev/msr121

Upreti, D. K., Nayaka, S. and Satya (2005): Enumeration of lichens from Madhya Pradesh and Chhattisgarh, India. - J. Appl. Biosci. 31(1): 55-63.

Vilgalys, R. and Hester, M. (1990): Rapid genetic identification and mapping of enzymatically amplified ribosomal DNA from several Cryptococcus species. - J. Bacteriol. 172: 4239-4246. https://doi.org/10.1128/jb.172.8.4238-4246.1990

Vondrák, J., Shahidin, H., Moniri, M. H., Halıc1, G. and Košnar, J. (2018): Taxonomic and functional diversity in Calogaya (lichenised Ascomycota) in dry continental Asia. Mycol. Progress 17: 897-916. https://doi.org/10.1007/s11557-018-1402-9

Vondrák, J., Frolov, I., Davydov, E. A., Yakovchenko, L., Malíček, J., Svoboda, S. and Kubásek, J. (2019): The lichen family Teloschistaceae in the Altai-Sayan region (Central Asia). - Phytotaxa 396: 1-66. https://doi.org/10.11646/phytotaxa.396.1.1

Wetmore, C. M. (2003): The Caloplaca squamosa group in North and Central America. Bryologist 106: 147-156. https://doi.org/10.1639/0007-2745(2003)106[0147:tcsgin]2.0.co;2

White, F. J. and James, P. W. (1985): A new guide to microchemical techniques for the identification of lichens substances. - Brit. Lich. Soc. Bull. 57(suppl.): 1-41.

White, T. J., Bruns, T., Lee, S. and Taylor, J. (1990): Amplification and direct sequencing of fungal ribosomal RNA genes for phylogenetics. - PCR Protocols 38: 315-322. https:// doi.org/10.1016/b978-0-12-372180-8.50042-1

Zahlbruckner, A. (1930): Lichenes. - In: Handel-Mazzetti, H. (ed.): Symbolae sinicae. Botanische Ergebnisse der Expedition der Akademie der Wissenschaften in Wien nach Südwest-China 1914-1918. III. J. Springer, Wien, 254 pp.

Open Access statement. This is an open-access article distributed under the terms of the Creative Commons Attribution-NonCommercial 4.0 International License (https://creativecommons.org/licenses/by-nc/4.0/), which permits unrestricted use, distribution, and reproduction in any medium for non-commercial purposes, provided the original author and source are credited, a link to the CC License is provided, and changes - if any - are indicated. 